MOACIR FRANCISCO DE BRITO

\title{
DETERMINAÇÃO DAS FRAÇÕES ORGÂNICAS DE EFLUENTES DE REATORES UASB
}




\title{
DETERMINAÇÃO DAS FRAÇÕES ORGÂNICAS DE EFLUENTES DE REATORES UASB
}

\author{
Dissertação apresentada à Escola \\ Politécnica da Universidade de São \\ Paulo para a obtenção do título de \\ Mestre em Engenharia \\ Área de Concentração: \\ Engenharia Hidráulica e Sanitária \\ Orientador: \\ Prof. Dr. Pedro Além Sobrinho
}

São Paulo

2006 
Aos meus Pais, sem os quais não chegaria até aqui.

À minha esposa e filhos, pela paciência, apoio e compreensão. 


\section{AGRADECIMENTOS.}

Ao Prof ${ }^{\circ}$ Dr. Pedro Alem Sobrinho, por sua orientação, pelo aprendizado inestimável durante este período, pela confiança em mim depositada e por crer no sucesso deste trabalho.

Ao pessoal de manutenção do CTH, em especial ao Sr. Adhemar Rizzoli, por sua imprescindível colaboração, para o funcionamento constante do reator UASB.

Aos professores, Dr. Roque Passos Pivelli, Dra. Dione Mari Morita, Dr. Sidney Seckler Ferreira Filho, Dr. Podalyro Amaral, Dra. Rosana Filomena Vazoller, Dra. Vivian, Dr. René Pete, pelos conhecimentos transferidos.

A todos os meus colegas de pós-graduação do PHD, em especial da minha turma, que através da amizade e apoio mútuo, deram coragem para seguir sempre em frente.

À Superintendência MT da SABESP, Departamento de tratamento MTT e a Divisão de Operação e Manutenção ETE - Barueri, por me permitir a execução deste trabalho, e usar seu espaço físico.

Aos funcionários da equipe do laboratório da ETE - Barueri e seu encarregado, Francisco Novaes, pelo apoio na execução das análises e operação do reator piloto.

Aos funcionários do Laboratório de Saneamento da EPUSP, Fábio, Laerte e Ângela, pela colaboração.

Aos funcionários do PHD, Iara, Ricardo e Odorico, pela paciência com as dúvidas e pela pronta colaboração. 
Aos Drs. Luiz Carlos Helou e Milton T. Tsutya, pelo apoio e críticas construtivas durante a execução do trabalho.

À minha esposa e meus filhos.

A todos que por ventura contribuíram direta e indiretamente para a realização deste trabalho. 
"Se o conhecimento pode causar problemas, não é através da ignorância que podemos solucioná-los. "Isaac Asimov" 


\section{RESUMO}

O tratamento de esgotos municipais através de reatores do tipo "Up-flow Anaerobic Slugde Blanket" - UASB, já são utilizados há vários anos em alguns estados do Brasil. Seu rendimento no tratamento está na faixa de 65 a $75 \%$ de remoção de carga orgânica medida em DBO, necessitando portanto de um pós - tratamento, por exemplo AERÓBIO, como Filtros Biológicos Percoladores, Filtros Biológicos submersos Aerados, Lodos Ativados etc. Devido a evolução da legislação e dos sistemas de tratamento no nível terciário, ou seja, remoção de nutrientes, estes pós tratamentos se fazem ainda mais necessários para remoção de nitrogênio amoniacal por exemplo, com remoção completa usando de nitrificação e denitrificação ou simplesmente atingindo o estágio de nitrificação, pois o nitrogênio amoniacal é tóxico para uma boa parcela da vida aquática, peixes principalmente, enquanto o nitrogênio na forma do íon nitrato ou nitrito é considerado menos tóxico. Já existe na literatura algumas descrições de como dimensionar tais unidades de pós tratamento, todavia, os parâmetros usados são teóricos e baseados nos já existentes para esgotos sanitários tipicamente domésticos, não havendo ainda uma fonte de dados experimentais para tais parâmetros. O intuito deste trabalho foi o de obter dados mais reais para projeto de pós - tratamento de efluentes de reatores UASB, usando o equacionamento e os métodos apresentados por Ekama, Dold e Marais (1986), baseado num sistema piloto de Lodos Ativados, em escala de laboratório, alimentado com efluente de um reator UASB instalado no campus da USP, mais precisamente no Centro Tecnológico de Hidráulica (CTH) da Escola Politécnica. Este reator trata o esgoto gerado no restaurante comunitário e apartamentos de moradia dos alunos (CRUSP), da Universidade. Como todos os sistemas biológicos aeróbios de tratamento se baseiam nas mesmas frações, os dados aqui obtidos são úteis para qualquer outro pós - tratamento aeróbio destes efluentes. As frações obtidas foram: $f_{u p}=0,15, f_{r b} \sim 0$ e $f_{u s}=0,2$.

Palavras Chaves: Frações de DQO, efluentes de UASB, lodos ativados, tratamento de esgoto. 


\begin{abstract}
The treatment of municipal wastewaters through "Up-flow Anaerobic with Sludge Blanket" - UASB reactors -, are already used for many years in some states of Brazil. It's output in the treatment is in the range of $65 \%$ to $75 \%$ of organic load remove in BOD, needing so an after-treatment, for example the AEROBIC, like Percolator Biologic Filters, aerated submerse Biological Filters, Activated Sludge etc. Due to the evolution of legislation and treatment systems in the tertiary level, that means, nutrients remove, these after-treatments are even more necessary to the removal of ammonia nitrogen for example, with complete removal using nitrification and denitrification or simply achieving the nitrification stage, because the ammonia is toxic to a great part of aquatic life, mostly fishes, while the nitrogen in the form of ions nitrate or nitrite is considered less toxic. There are already in the literature some descriptions of how to dimension those units of after-treatment, however, the parameters used are theoretical and based on the pre-existent to sanitary wastewater typically domestic, not having yet a source of experimental data for those parameters. The objective of this paper is to get real data to project the aftertreatment of effluents of UASB reactors, using the equation and the methods presented by Ekama, Dold e Marais (1986), based in a pilot system of Activated Sludge, in laboratory level, fed with effluent of an UASB reactor installed on the campus of USP, more precisely in the Hydraulic Technological Center (CTH). This reactor treats the wastewater generated in the communitary restaurant and apartments where the University students live (CRUSP). Like all the aerobic biologic systems of treatment base themselves in the same fractions, the collected data here are really useful to any other aerobic after-treatment of these effluents. The fractions obtained were: $f_{u p}=0,15, f_{r b} \sim 0$ and $f_{u s}=0,2$.
\end{abstract}




\section{LISTA DE FIGURAS}

Figura 1 - Esquema simplificado da digestão anaeróbia.............................................24

Figura 2 - Reator de fluxo tendendo à pistão............................................................26

Figura 3 - Esquema de Funcionamento de um Reator UASB ....................................28

Figura 4 - Esquema de um sistema de lodos ativados convencional..........................39

Figura 5 - Lodos Ativados em Batelada..............................................................4

Figura 6 - Esquema de um sistema de pós - desnitrificação.........................................49

Figura 7 - Esquema de um sistema com Pré - desnitrificação.....................................50

Figura 8 - Sistemas modificados para remoção de fósforo..........................................52

Figura 9 - Fracionamento da Matéria Orgânica Afluente expressa em DQO.............53

Figura 10 - Distribuição da Matéria Orgânica Afluente...............................................56

Figura 11 - Distribuição da Matéria Orgânica Afluente.............................................57

Figura 12 - Representação esquemática da respiração pela biomassa

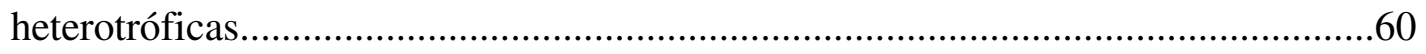

Figura 13 - modelo tradicional (a) e modelo "morte - regeneração"(b)....................61

Figura 14 - Ilustração das formas de medida do oxigênio consumido........................62

Figura 15 - Esquema básico de um respirômetro de medida em batelada com controle automático e interfaceado a um microcomputador..........................................64

Figura 16 - Desenho sem escala do reator UASB do CTH.........................................66

Figura 17 - Gráfico do comportamento da TCO em função do tempo..........................70

Figura 18 - Diagrama do sistema piloto em escala de laboratório.................................77 
Figura 19 - Tela do programa do respirômetro Resp32C - Lodo ativado sem

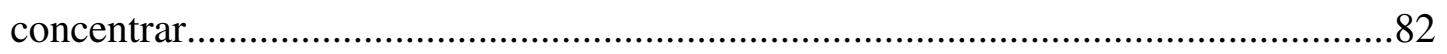

Figura 20 - Tela do programa do respirômetro Resp32C - lodo ativado concentrado 4

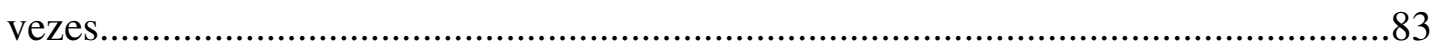




\section{LISTA DE FOTOS}

Foto 1 - Floco Biológico de Lodos Ativados "Aberto" - Cortesia Sabesp - ETE -

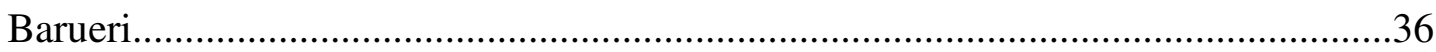

Foto 2 - Floco Biológico de Lodos Ativados "Filamentoso" - Cortesia Sabesp -

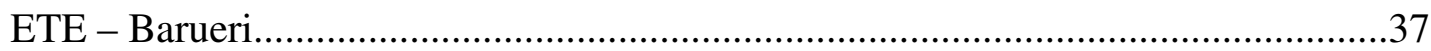

Foto 3 - Tanque de Aeração por Ar Difuso - Cortesia Sabesp - ETE - Barueri.......38

Foto 4 - Decantador Secundário Circular - Cortesia Sabesp - ETE - Barueri.........40

Foto 5 - Vertedouro do Decantador Secundário - Cortesia Sabesp - ETE -

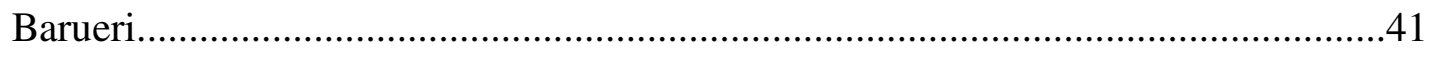

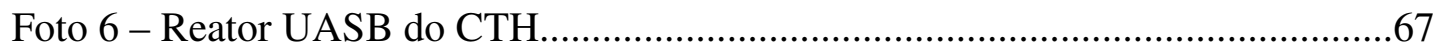

Foto 7 - Sistema de Lodos Ativados em escala de laboratório..................................77 


\section{LISTA DE TABELAS}

Tabela 1 - Taxas de aplicação superficial e tempos de detenção hidráulico no compartimento de decantação do reator UASB.

Tabela 2 - Velocidades nas aberturas (passagens) para o decantador do reator UASB

Tabela 3 - Parâmetros analisados no afluente e efluente do reator piloto com seus respectivos métodos .68

Tabela 4 - Concentração de SST e SSV no reator piloto (2004 a 2005)......................78

Tabela 5 - monitoramento do efluente do reator UASB (Afluente ao sistema

Piloto) 80

Tabela 6 - Variação das características do efluente do sistema piloto..........................84

Tabela 7 - Resultados do ensaio de digestão do lodo ativado do sistema piloto........85

Tabela 8 - Valores das frações de DQO para esgotos tipicamente domésticos e os encontrados para o efluente de UASB. 


\section{LISTA DE ABREVIATURAS E SÍMBOLOS}

$\begin{array}{llc}\varnothing & \text { Diâmetro } & {[\mathrm{L}]} \\ \theta_{c} & \text { Idade do Lodo ou TRS } & {[\mathrm{L}]} \\ \theta h & \text { tempo de detenção hidráulico } & {[\mathrm{T}]} \\ \mu_{\operatorname{máx}} & \text { Taxa de crescimento máxima dos microorganismos } & {[\mathrm{T}]^{-1}} \\ \theta_{T} & \text { coeficiente de temperatura } & \\ { }^{\circ} \mathrm{C} & \text { Graus centígrados } & \\ \text { A } & \text { Área } & {[\mathrm{L}]^{2}} \\ \text { A/M } & \text { Relação alimento microorganismo } & {[\mathrm{T}]^{-1}}\end{array}$

BARDENPHO Sistema patenteado de tratamento de efluentes nível terciário

$b_{h} \quad$ Coeficiente (taxa) de decaimento $\quad[\mathrm{T}]^{-1}$

CB Carga Biológica ou carga de lodo $\quad[\mathrm{T}]^{-1}$

CHV Carga hidráulica volumétrica $\quad[\mathrm{T}]^{-1}$

COV Carga Orgânica Volumétrica $\quad[\mathrm{M}] \cdot[\mathrm{L}]^{-3} \cdot[\mathrm{T}]^{-1}$

CRUSP Centro Residencial da Universidade de São Paulo

CTH Centro Tecnológico de Hidráulica

DBO Demanda Bioquímica de Oxigênio $\quad[\mathrm{M}] \cdot[\mathrm{L}]^{-3}$

DP-Médio Desvio Padrão médio

DP-Normal Desvio Padrão normal

DQO Demanda Química de Oxigênio $\quad[\mathrm{M}] \cdot[\mathrm{L}]^{-3}$

$\mathrm{DQO}_{\mathrm{Lb}} \quad$ Concentração de substrato lentamente biodegradável $\quad[\mathrm{M}] \cdot[\mathrm{L}]^{-3}$

$\mathrm{DQO}_{\mathrm{rb}} \quad$ Concentração de substrato rapidamente biodegradável $\quad[\mathrm{M}] \cdot[\mathrm{L}]^{-3}$ 


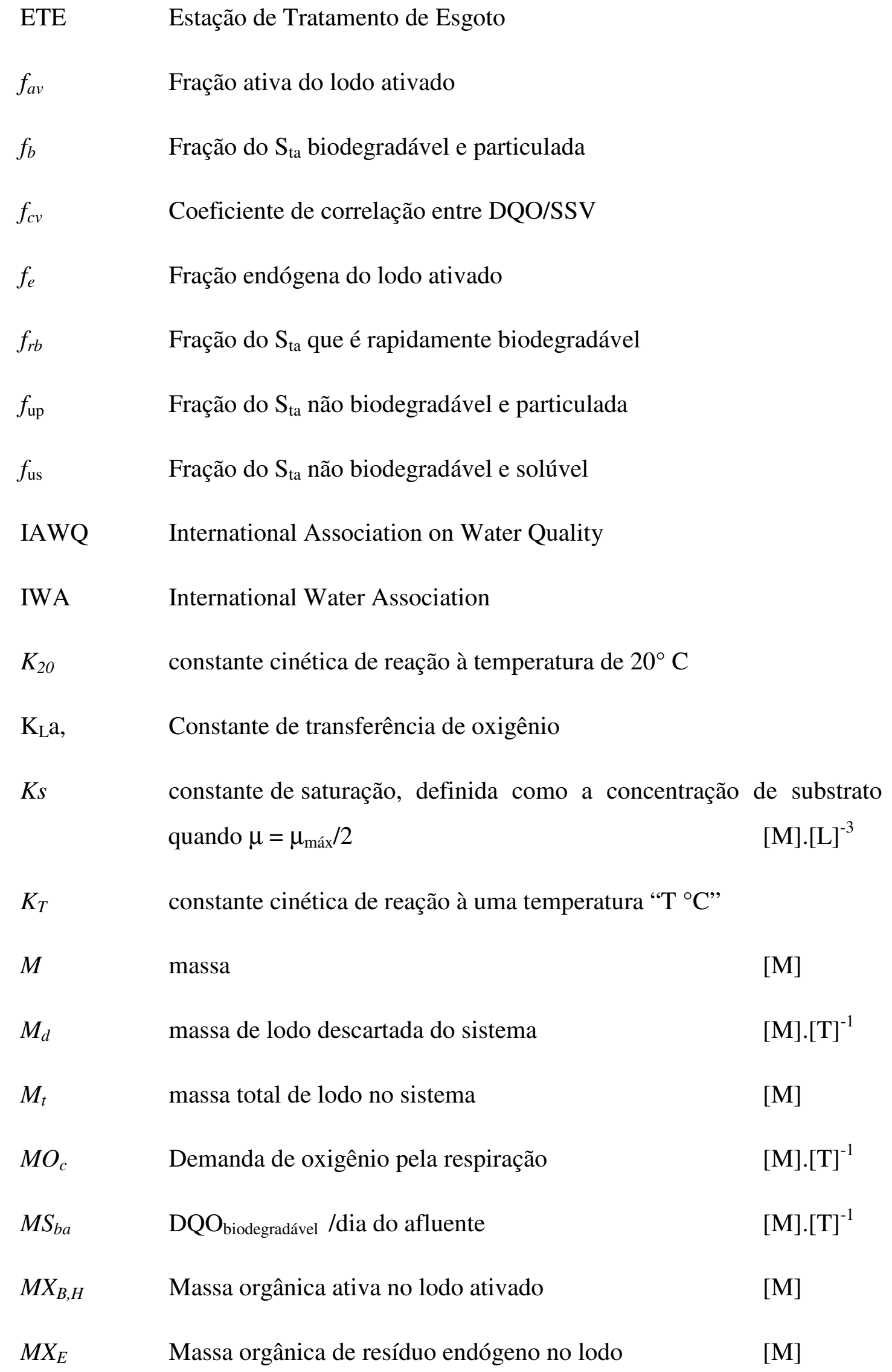




\begin{tabular}{|c|c|}
\hline$M X_{I}$ & Massa orgânica inerte no lodo \\
\hline$M X_{v}$ & Massa orgânica total no lodo \\
\hline $\mathrm{N}-\mathrm{NH}_{3}$ & Nitrogênio amoniacal \\
\hline $\mathrm{N}-\mathrm{NO}_{3}^{-}$ & Nitrogênio nitrato \\
\hline OD & Concentração de oxigênio dissolvido no meio líquido \\
\hline $\mathrm{pH}$ & Potencial hidrogeniônico $\equiv$ co-logaritmo da concentração molar de $\mathrm{H}^{+}$ \\
\hline$Q$ & {$[\mathrm{~L}] .[\mathrm{T}]^{-1}$} \\
\hline $\mathrm{rpm}$ & Rotações por minuto \\
\hline$S$ & Concentração de substrato no afluente, expressa em DQO [M].[L] $]^{-3}$ \\
\hline$S_{b a}$ & $\begin{array}{l}\text { Concentração de substrato orgânico biodegradável total afluente, } \\
\text { expressa em DQO } \\
{[\mathrm{M}] .[\mathrm{L}]^{-3}}\end{array}$ \\
\hline$S_{\text {bpa }}$ & $\begin{array}{l}\text { Concentração de substrato orgânico biodegradável particulado } \\
\text { afluente, expressa em DQO } \\
{[\mathrm{M}] .[\mathrm{L}]^{-3}}\end{array}$ \\
\hline$S_{b s a}$ & $\begin{array}{l}\text { Concentração de substrato orgânico biodegradável solúvel afluente, } \\
\text { expressa em DQO } \\
{[\mathrm{M}] .[\mathrm{L}]^{-3}}\end{array}$ \\
\hline $\mathrm{S}_{\mathrm{rb}}$ & $\begin{array}{l}\text { Concentração de substrato rapidamente biodegradável, expressa em } \\
\text { DQO } \\
{[\mathrm{M}] .[\mathrm{L}]^{-3}}\end{array}$ \\
\hline$S_{t a}$ & Concentração de substrato total afluente, expressa em DQO $[\mathrm{M}] .[\mathrm{L}]^{-3}$ \\
\hline$S_{u a}$ & $\begin{array}{l}\text { Concentração de substrato orgânico não-biodegradável total afluente, } \\
\text { expressa em DQO } \\
{[\mathrm{M}] .[\mathrm{L}]^{-3}}\end{array}$ \\
\hline$S_{\text {upa }}$ & $\begin{array}{l}\text { Concentração de substrato orgânico não-biodegradável particulada } \\
\text { afluente, expressa em DQO } \\
{[\mathrm{M}] .[\mathrm{L}]^{-3}}\end{array}$ \\
\hline$S_{u s a}$ & $\begin{array}{l}\text { Concentração de substrato orgânico não-biodegradável solúvel } \\
\text { afluente, expressa em DQO } \\
{[\mathrm{M}] \cdot[\mathrm{L}]^{-3}}\end{array}$ \\
\hline
\end{tabular}




\begin{tabular}{|c|c|c|}
\hline SS & Sólidos em Suspensão & {$[\mathrm{M}] .[\mathrm{L}]^{-3}$} \\
\hline SSed & Sólidos Sedimentáveis & \\
\hline SST & Sólidos em Suspensão Totais & {$[\mathrm{M}] .[\mathrm{L}]^{-3}$} \\
\hline SSV & Sólidos em Suspensão Voláteis & {$[\mathrm{M}] \cdot[\mathrm{L}]^{-3}$} \\
\hline$T$ & temperatura & \\
\hline$t$ & tempo & \\
\hline$\mu$ & Taxa de crescimento específica dos microorganismos & {$[\mathrm{T}]^{-1}$} \\
\hline $\mathrm{TCO}$ & Taxa de consumo de oxigênio ou Taxa respirométrica & {$[\mathrm{M}] \cdot[\mathrm{L}]^{-3} \cdot[\mathrm{T}]^{-1}$} \\
\hline TRS & Tempo de Retenção de Sólidos & {$[\mathrm{T}]^{-1}$} \\
\hline UASB & Reator Anaeróbio de fluxo ascendente e manto de lodo & \\
\hline UCT & University of Cape Town & \\
\hline USP & Universidade de São Paulo & \\
\hline$V$ & Volume & \\
\hline $\mathrm{X}_{\mathrm{a}}$ & Concentração de biomassa ativa & {$[\mathrm{M}] \cdot[\mathrm{L}]^{-3}$} \\
\hline$X_{b}$ & Concentração de biomassa ativa biodegradável & {$[\mathrm{M}] \cdot[\mathrm{L}]^{-3}$} \\
\hline $\mathrm{X}_{\mathrm{e}}$ & Concentração Resíduo endógeno & {$[\mathrm{M}] .[\mathrm{L}]^{-3}$} \\
\hline $\mathrm{X}_{\mathrm{s}}$ & Concentração de substrato Lentamente biodegradável & {$[\mathrm{M}] \cdot[\mathrm{L}]^{-3}$} \\
\hline$X_{v}$ & Concentração de sólidos em suspensão voláteis & {$[\mathrm{M}] .[\mathrm{L}]^{-3}$} \\
\hline $\mathrm{X}_{\mathrm{v} \infty}$ & \multicolumn{2}{|c|}{ Massa final de SSV (após a digestão por um tempo específico) $[\mathrm{M}]$} \\
\hline $\mathrm{X}_{\mathrm{vi}}$ & Massa de SSV inicial & {$[\mathrm{M}]$} \\
\hline$Y, Y_{h}$ & Coeficiente de rendimento & \\
\hline
\end{tabular}




\section{SUMÁRIO}

1. INTRODUÇÃO

2. OBJETIVOS

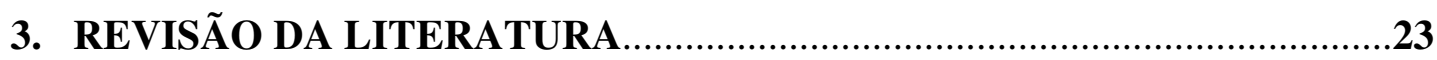

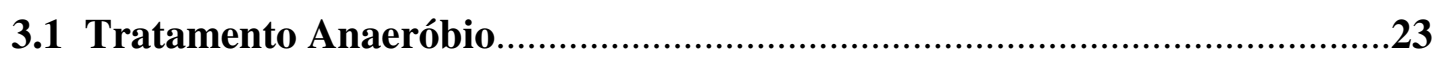

3.2 Reatores Anaeróbios de Fluxo Ascendente e Manta de Lodo - UASB.........25

3.3 Características do reator UASB

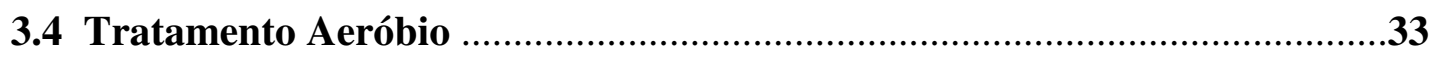

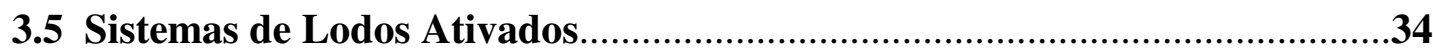

3.5.1 Sistemas de Lodos Ativados com remoção Biológica de Nutrientes.........48

3.5.2 Fracionamento da Matéria Orgânica Afluente............................................53

3.5.3 Metodologias de Determinação da Taxa de Consumo (Utilização) de

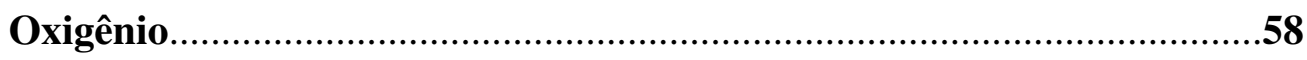

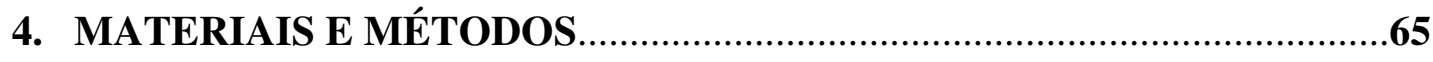

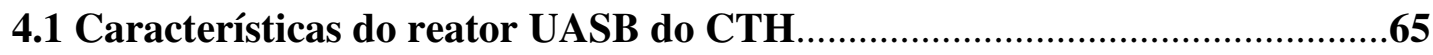

4.2 Métodos Analíticos usados para determinação dos parâmetros físico -

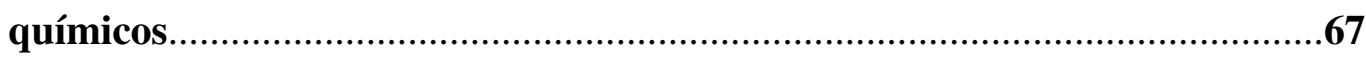

4.3 Métodos para determinação das frações de DQO...........................................68

4.3.1 Determinação da fração de DQO solúvel não biodegradável...................69

4.3.2 Determinação da fração de DQO rapidamente biodegradável $\left(f_{\text {rb }}\right)$.........69

4.3.3 Determinação da fração de DQO particulada não biodegradável $\left(f_{\text {up }}\right) \ldots 70$

4.3.4 Equações definidas no Modelo em Regime Permanente - (Marais, G.R.V.

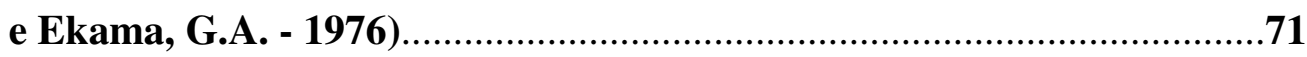


4.4 Método para a determinação da Taxa de Consumo de Oxigênio (TCO).....73

4.5 Sistema Piloto de Lodos Ativados operando em regime permanente............75

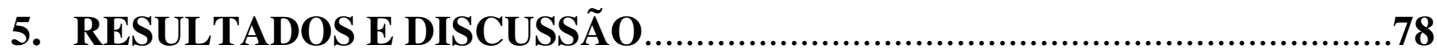

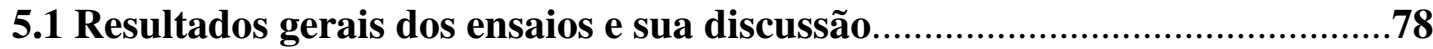

5.2 Determinação das frações do Substrato (em DQO) do Efluente do Reator

UASB.

.86

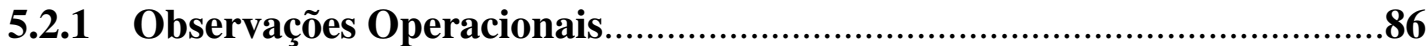

5.2.2 Dados obtidos do Piloto de Lodos Ativados.............................................86

5.2.3 Determinação de $f_{a v}$ através da digestão aeróbia do lodo ativado...........87

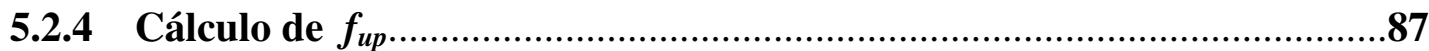

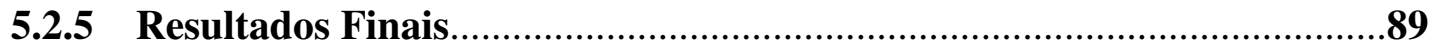

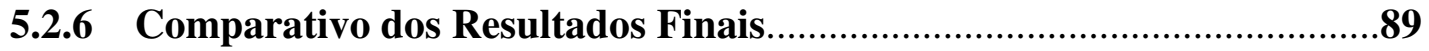

6. CONCLUSÕES E RECOMENDAÇÕES...................................................

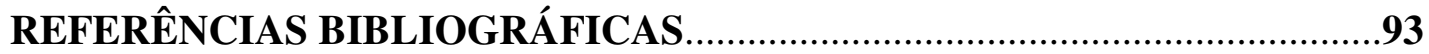

ANEXOS 


\section{INTRODUÇÃO}

O tratamento de esgotos por processos biológicos anaeróbios, particularmente com a utilização de reatores anaeróbios de fluxo ascendente e manto de lodo (reatores UASB) teve um grande desenvolvimento nos últimos anos no Brasil, particularmente em vista das condições climáticas favoráveis e das vantagens energéticas que pode proporcionar ao tratamento de esgotos como um todo. Os reatores UASB têm uma eficiência de aproximadamente 65 - 70\% em remoção de matéria orgânica biodegradável, o que é um valor razoável para um sistema anaeróbio de tratamento. Todavia, os efluentes desse processo de tratamento não atendem à legislação ambiental em vigor, pois além do residual de matéria orgânica no efluente ainda ser alta para o lançamento em corpos de água receptores, os reatores anaeróbios não removem ou oxidam nitrogênio amoniacal, que também se enquadra como parâmetro de emissão de efluentes de estações de tratamento de esgotos (ETEs). Isto implica na necessidade de um tratamento adicional para efluentes de sistemas de tratamento anaeróbio utilizando reatores UASB, que na maioria dos casos se dá através de tratamento biológico aeróbio.

Dentre os processos aeróbios de tratamento de efluentes de reatores anaeróbios, o de lodos ativados é um dos que apresenta grande potencial de uso. Embora bastante estudado e com vários modelos cinéticos desenvolvidos, os parâmetros de dimensionamento disponíveis na literatura e largamente utilizados são para esgoto decantado ou apenas gradeado e desarenado. Para efluentes de reatores UASB apenas alguns parâmetros para modelos de dimensionamento empíricos têm sido obtidos em trabalhos desenvolvidos nos últimos anos.

Existem alguns métodos na literatura para obter o balanço de massas em sistemas de lodos ativados. Contudo, como demonstrado por van Haandel e Marais, o balanço de massas da matéria orgânica quando feito a partir da medida em DBO, traz várias distorções, basicamente por dois motivos: $1^{\circ}$ - A medida de DBO têm um erro analítico bem maior na sua determinação do que a DQO; $2^{\circ}$ - O cálculo pela DBO 
não leva em conta a formação de resíduo endógeno, vindo da biodegradação celular das bactérias do lodo ativo.

Rozich e Gaudy (1992) também propuseram um modelo matemático baseado em DQO, devido à praticidade desta medida. Porém, dentro do seu modelo não existe a fração relacionada ao resíduo endógeno formado do decaimento celular, como proposto por Marais e Ekama (1976).

Para o uso de modelos de dimensionamento mais racionais, como o modelo simplificado desenvolvido pela equipe do Prof. Marais na Universidade de Cape Town (UCT), na África do Sul, que é a base para o modelo utilizado pela International Water Association (IWA), não são disponíveis os parâmetros relativos às parcelas da matéria orgânica do efluente de sistemas de tratamento anaeróbio, fundamentais para o uso do referido modelo de dimensionamento.

O presente trabalho procura estudar o comportamento do processo de lodos ativados, especificamente quanto a biodegradabilidade, para o pós - tratamento do efluente de reatores UASB, através da determinação das frações da DQO do efluente desses reatores anaeróbios, tendo em conta que, de forma geral, as rotas metabólicas são basicamente as mesmas em todos os processos de tratamento biológicos aeróbios, e por consequiência a cinética e estequiometria de todos eles partem das mesmas constantes, como por exemplo: taxa de crescimento, taxa de decaimento, rendimento na geração de nova biomassa, e fração orgânica biodegradável e não biodegradável da biomassa gerada.

Assim, o objetivo deste trabalho é determinar as várias frações da matéria orgânica para tratamento biológico aeróbio do efluente de um reator UASB, no caso específico, o reator instalado no campus desta universidade, no Centro de Tecnologia em Hidráulica (CTH) da Escola Politécnica.

Pelas razões expostas, escolheu-se realizar o balanço de massas e modelagem matemática com a medida de matéria orgânica em DQO, que por consequiência limita a escolha de metodologia em apenas algumas, na maioria propostas pelo grupo de pesquisa da UCT, que foi a base usada para este trabalho. 
O procedimento adotado para determinar a fração rapidamente biodegradável envolve a técnica de respirometria ou Taxa de Consumo de Oxigênio (TCO), a qual necessita de um lodo ativado já adaptado ao efluente a ser tratado, ou seja, necessita de um sistema de Lodos Ativados tratando este efluente por pelo menos três vezes o tempo de retenção de sólidos no reator (ou idade do lodo), servindo como fonte de lodo para o ensaio.

No procedimento para determinar a fração solúvel não biodegradável e a fração particulada não biodegradável, também é necessário um reator piloto de lodos ativados, porém operando em regime permanente em relação à carga orgânica, ou seja, alimentando o sistema sempre com a mesma quantidade de matéria orgânica aplicada por dia. Desta forma, com um único reator piloto de lodos ativados, são satisfeitas as necessidades dos dois procedimentos.

Como a metodologia e o sistema piloto foram projetados para operar em regime permanente, as equações para este trabalho se tornam mais simples, sendo usado então o equacionamento "simplificado" para regime permanente. 


\section{2- OBJETIVOS}

Este estudo tem como objetivo principal a determinação das várias frações da matéria orgânica efluente de um reator do tipo UASB, na forma de DQO, através de um reator piloto de lodo ativado, usando método e modelo matemático proposto por Ekama, Dold e Marais (1986).

As frações de DQO do efluente de reator UASB que foram determinadas são:

- $\quad$ Fração rapidamente biodegradável $\left(f_{r b}\right)$

- Fração solúvel não biodegradável $\left(f_{u s}\right)$

- Fração particulada não biodegradável $\left(f_{u p}\right)$ 


\section{REVISÃO DA LITERATURA}

\subsection{Tratamento Anaeróbio}

Os microorganismos envolvidos numa digestão anaeróbia são de uma grande variedade de espécies, os quais formam um consórcio, que irá digerir a matéria orgânica presente através de processo fermentativo. Este processo gera pouca energia se comparado aos processos oxidativos aeróbios ou anóxicos, razão pela qual gera-se menos lodo em relação a estes últimos. Em suma, para adquirirem energia suficiente para suas funções celulares vitais e reprodutivas, precisam fermentar uma quantidade bem maior de matéria orgânica em comparação com o metabolismo aeróbio. Segundo van Haandel e Marais (1999), para esgotos tipicamente domésticos, enquanto numa digestão aeróbia o aproveitamento da matéria orgânica para gerar novas células está em torno de 2/3 em massa de matéria orgânica (medida em DQO) biodegradável, enquanto na digestão anaeróbia se aproxima de 1/10.

Em um sistema anaeróbio, as vias metabólicas são tão variadas quanto o número de microorganismos envolvidos, tornando o conhecimento em detalhes deste processo muito complexo. Como o escopo deste trabalho é o pós - tratamento do efluente de um reator anaeróbio, a explanação sobre este assunto se fará apenas nas três etapas básicas do processo em questão.

As três etapas, são as seguintes:

A - Hidrólise: Nesta etapa as macro moléculas orgânicas, como por exemplo proteínas, polissacarídeos e gorduras, são "quebradas" em moléculas menores e mais simples.

B - Acidogênese/Acetogênese: A partir das moléculas orgânicas menores formadas na primeira etapa, é efetuada uma nova "quebra" destas, transformando-as em moléculas ainda mais simples, na maioria ânions de ácidos orgânicos voláteis como piruvatos, propionatos etc, levados posteriormente a acetatos. Também há a formação de gás carbônico e hidrogênio. 
C - Metanogênese: Esta etapa final é efetuada por um grupo de bactérias específicas e estritamente anaeróbias conhecidas como metanogênicas. Estas conseguem, através do substrato presente (acetato, hidrogênio, gás carbônico etc.), produzir o gás metano.

Observa-se, portanto, que a matéria orgânica complexa introduzida no início do processo, é gradativamente decomposta até atingir a forma mais simples que é a do gás metano. Além disto, também se observa que as etapas, em função de serem um efeito "cascata" todas são interdependentes, ou seja, se uma não funcionar as outras também não funcionam. Mesmo a etapa da metanogênese, que é a última, se houver inibição desta, a acidez dentro do digestor sobe até romper o efeito tampão natural formado pelo consórcio microbiano, trazendo com isso uma queda no $\mathrm{pH}$, que acabará por inibir ou interferir nos outros dois processos. A figura 1 traz um quadro resumo facilitando a visualização destas etapas. (Foresti, E. et al - 1999)

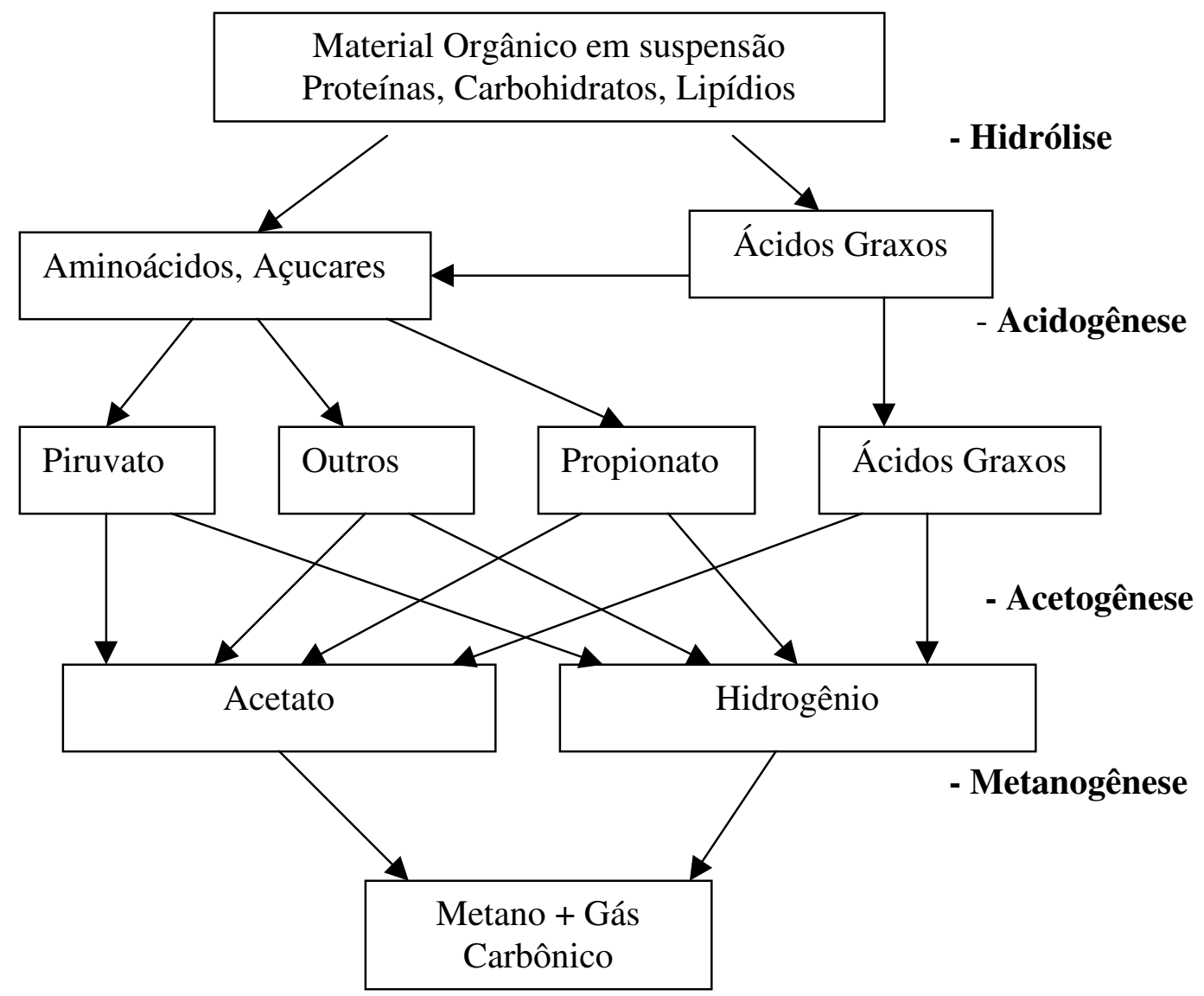

Figura 1 - Esquema simplificado da digestão anaeróbia - adaptada de Foresti (-1999) 
Um outro aspecto importante durante o processo fermentativo, é que o potencial redutor contido na matéria orgânica afluente é transferido para o gás metano. Desta forma, o que se constata é que a DQO removida do líquido só ocorre devido à transferência para o gás metano (van Haandel e Marais-1999).

\subsection{Reatores Anaeróbios de Fluxo Ascendente e Manta de Lodo - UASB}

A escolha entre as várias configurações existentes de reatores, para o tratamento anaeróbio de esgotos domésticos, como em qualquer projeto, depende de condições como custo, demanda de área, eficiência necessária, variação de vazão, mão de obra necessária para operação e manutenção etc.

Os reatores podem ter duas formas operacionais, descontínuo e contínuo. Para um sistema descontínuo tem-se o reator do tipo Batelada, para um sistema contínuo tem-se os reatores do tipo Pistão ou Tubular e Mistura Completa. De fato, estes dois últimos só existem teoricamente, pois na prática o que se tem é uma mistura dos dois, com uma tendência maior por um ou outro. Assim sendo, quando se descreve as características de um destes dois reatores, eles são chamados de reator com fluxo tendendo a pistão ou tendendo a mistura completa. (Fogler - 1992)

No caso de um reator anaeróbio tipo batelada, a operação do mesmo é dividida em quatro etapas:

- Enchimento: operação de carga do reator;

- Reação: processo de digestão da matéria orgânica através de fermentação;

- Sedimentação: operação de separação do resíduo sólido e

- Esvaziamento: operação de descarga do efluente tratado.

Os reatores UASB são do tipo com fluxo contínuo e tendendo a pistão, os quais se assemelham em termos de eficiência a um reator tipo batelada. Os reatores de mistura completa têm normalmente uma menor eficiência em relação aos outros dois, porém, são menos sensíveis à cargas de choque. (Kato et al - 1999) 
A forma física de um reator de fluxo tendendo à pistão tem grande influência na sua eficiência, pois nestes reatores o fluxo do líquido é tal que ocorre pouca mistura tanto no sentido vertical como no horizontal enquanto passa pelo reator. Para isto é necessário que o reator seja estreito no sentido do fluxo, de forma que haja pouca dispersão longitudinal do material a ser degradado no líquido. Durante o percurso dentro do reator, a matéria orgânica vai sendo degradada, de forma que a concentração do substrato forma um gradiente dentro do reator: mais concentrada na entrada e menos na saída do reator (Levenpiel - 1972). A figura 2 ilustra o funcionamento deste tipo de reator. (Vide anexo A)

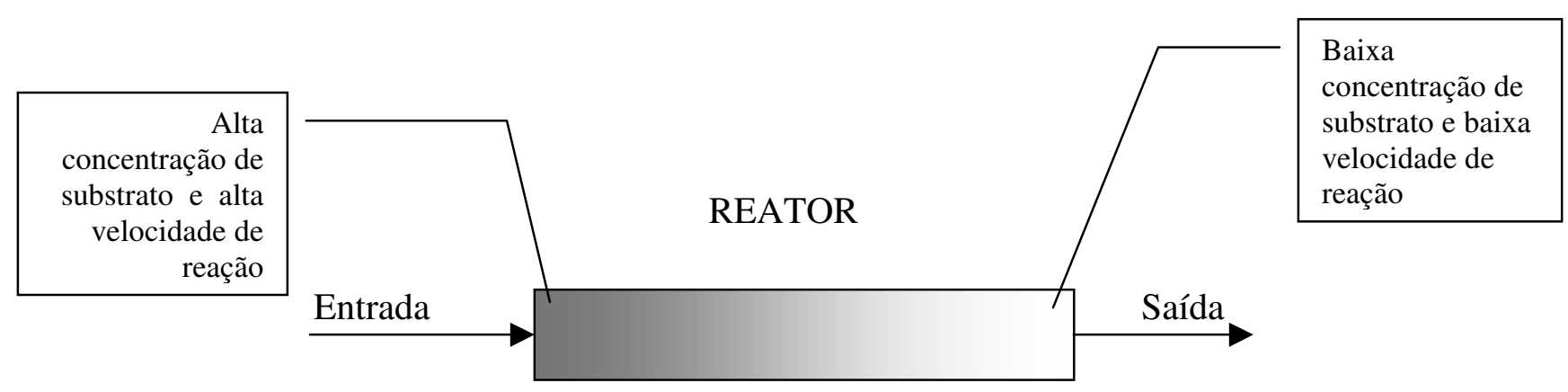

Concentração de substrato

Figura 2 - Reator de fluxo à pistão ideal - adaptado de Kato et al (1999)

Obviamente, há muito mais sobre a teoria de reatores do que foi exposto, contudo, não é a pretensão nem o objetivo deste trabalho discutir tais teorias.

Torna-se claro que o tempo de detenção do líquido no reator, a uniformidade da vazão e a concentração de substrato no líquido são importantes para o projeto destes reatores. Com o intuito de esclarecer um pouco mais sobre o funcionamento e projeto dos reatores UASB, serão apresentado mais adiante os parâmetros mais usados no projeto destes reatores.

Os de Reatores do tipo UASB para tratamento de esgotos tipicamente domésticos já são utilizados em diversas localidades no Brasil, sendo que estas 
experiências têm se mostrado bem sucedidas. As vantagens do uso de tais reatores estão em algumas de suas características, tais como (Chernicaro et al, - 1999):

- Sistema compacto, com baixa demanda de área;

- Baixo custo de implantação e operação;

- Baixa produção de lodo;

- Baixo consumo de energia;

- $\quad$ Remoção de DBO e DQO razoável (da ordem de 65 a 75\%)

- Possibilidade de paradas e reinicio rápido;

- Elevada concentração do lodo excedente - conseqüente facilidade no desaguamento do lodo;

As desvantagens deste sistema são as seguintes:

- Possibilidade de emanação de maus odores;

- Baixa tolerância à cargas tóxicas;

- Partida lenta, ou seja, muito tempo para o sistema entrar em regime na primeira vez;

- Necessidade de um pós - tratamento.

No que tange às dificuldades da partida do sistema, esta pode ser amenizada através do uso de inóculo. Através da adição de pequenas quantidades, menores que $4 \%$ do volume do reator, consegue-se uma estabilidade do sistema de 2 a 3 semanas, contra 4 a 6 meses sem a aplicação do inóculo ( Chernicharo \& Borges, 1996).

Os Reatores do tipo UASB, são reatores biológicos de fluxo tendendo a pistão, assim como os filtros biológicos anaeróbios. A diferença é que nos reatores UASB, os microorganismos não estão fixos a um suporte, e sim formando pequenos grânulos de 1 a 5mm, que se mantém em suspensão devido ao fluxo ascendente do 
efluente à ser tratado. Então, enquanto o líquido atravessa o manto formado por estes grânulos, os microorganismos digerem a matéria orgânica contida no líquido e nos sólidos em suspensão. A figura 3 mostra um esquema de funcionamento de um reator UASB , que facilita o entendimento desta descrição (Chernicaro et al, - 1999).

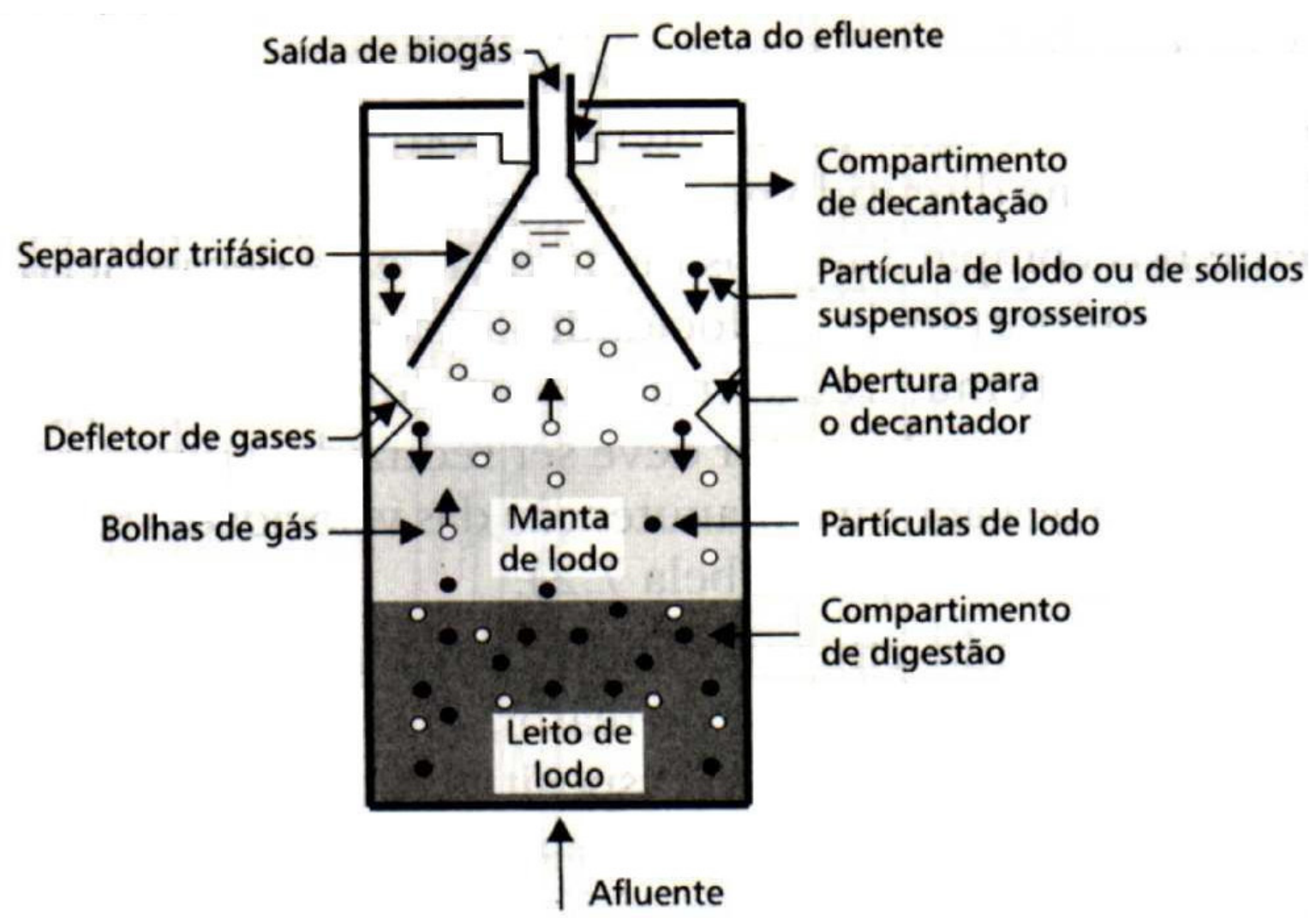

Figura 3 - Esquema de Funcionamento de um Reator UASB - Adaptado de Chernicaro et al (1999).

\subsection{Características do reator UASB}

Como pode ser observado na figura 03 , o esgoto a ser tratado entra através de tubulações de distribuição no fundo do reator, ascendendo entre o manto de lodo formado, onde ocorre a maior parte da biodegradação da matéria orgânica. Após o 
manto de lodo denso, o líquido encontra uma camada de lodo mais dispersa e menos densa até chegar ao topo, onde passa por um separador trifásico.

Neste ponto, o lodo residual que é arrastado pelo fluxo ou por bolhas de gás, é separado do líquido efluente no separador trifásico, retornando por gravidade para o fundo do reator. O gás por sua vez é também separado, deixando o líquido e sendo conduzido por um sistema de coleta que leva o gás para fora do reator, onde pode ser queimado com o uso de um queimador ou disperso na atmosfera.

Um reator UASB é dimensionado através dos seguintes parâmetros basicamente:

\section{A - Carga Orgânica Volumétrica}

Segundo a literatura (Foresti et al - 1999), o dimensionamento de um reator UASB por carga orgânica volumétrica é dada por: $C O V=\frac{Q \cdot S}{V}$

Onde $: C O V=$ Carga orgânica volumétrica $\left(\mathrm{kgDQO} / \mathrm{m}^{3} \cdot\right.$ dia $)$

$Q=\operatorname{Vazão}\left(\mathrm{m}^{3} /\right.$ dia $)$

$S=$ Concentração de substrato no afluente $\left(\mathrm{kg} \mathrm{DQO} / \mathrm{m}^{3}\right)$

$V=$ Volume total do reator $\left(\mathrm{m}^{3}\right)$

Como se pode observar na equação, o conceito deste parâmetro é saber a quantidade de matéria orgânica expressa em DQO que se aplica por unidade de volume do reator, por uma unidade de tempo. O número aceito para este parâmetro é de até $15 \mathrm{kgDQO} / \mathrm{m}^{3}$.dia, tendo alcançado em alguns casos experimentais até 45 $\mathrm{kgDQO} / \mathrm{m}^{3}$.dia .

Dado o fato de que o esgoto doméstico geralmente não ultrapassa a faixa de $1 \mathrm{kgO}_{2} / \mathrm{m}^{3}$ medido em DQO, o que se torna fator limitante para projeto destes reatores, no caso de esgotos domésticos, são as taxas hidráulicas no reator.

\section{B - Carga Hidráulica Volumétrica e Tempo de Detenção Hidráulico}


Define-se carga hidráulica volumétrica pelo volume de esgoto aplicado diariamente no reator (vazão), por unidade de volume do mesmo. O tempo de detenção hidráulico é o inverso da carga hidráulica (Chernicaro et al - 1999). A seguir as equações que os definem:

$C H V=\frac{Q}{V} \quad$ (2) $\quad$ e $\quad \theta h=\frac{V}{Q}(3)$

$C H V=$ Carga hidráulica volumétrica

$\theta h=$ tempo de detenção hidráulico

$Q=\operatorname{Vazão}\left(\mathrm{m}^{3} / \mathrm{dia}\right)$

$V=$ Volume total do reator $\left(\mathrm{m}^{3}\right)$

Segundo os autores, dados experimentais demostraram que o valor da $\mathrm{CHV}$ não deve ultrapassar $5,0 \mathrm{~m}^{3} / \mathrm{m}^{3}$.dia, que corresponde a um tempo de detenção de 4,8 horas.

\section{C - Carga Biológica ou Carga de Lodo}

Este parâmetro se assemelha à relação Alimento/Microorganismo usada em lodos ativados, e é definido como a carga orgânica aplicada ao reator por dia por unidade de biomassa. (Chernicaro et al - 1999)

$C B=\frac{Q \cdot S}{M}$

Onde:

$C B=$ carga biológica ou carga de lodo (kgDQO/kgSV.dia)

$Q=\operatorname{vazão}\left(\mathrm{m}^{3} / \mathrm{dia}\right)$

$S=$ concentração do substrato afluente $\left(\mathrm{kgDQO} / \mathrm{m}^{3}\right)$

$M=$ massa teórica de microorganismos presente no reator $(\mathrm{kgSV})$ 
Segundo a literatura, a maior importância deste parâmetro é na partida do reator, onde se aconselha mante-lo na ordem de 0,05 a 0,15 kgDQO/kgSV.dia.

Uma vez em regime, no caso de esgotos domésticos, a faixa de trabalho pode passar a ser de 0,3 a 0,4 kgDQO/kgSV.dia. É claro que estes números são apenas uma referência, pois depende das características do afluente ao digestor. (Chernicaro et al - 1999)

\section{D - Velocidade Ascendente do Fluxo}

A velocidade ascendente do líquido dentro do reator tem sua importância no processo de separação das fases na saída do reator, ou seja, no separador trifásico.

Este parâmetro é calculado como segue:

$V=\frac{Q}{A}$

onde:

$V=$ velocidade ascendente do fluxo, ou velocidade ascensional $(\mathrm{m} / \mathrm{h})$

$Q=\operatorname{vazão}\left(\mathrm{m}^{3} / \mathrm{h}\right)$

$A$ = área da seção transversal do reator $\left(\mathrm{m}^{2}\right)$

A faixa ideal deste parâmetro depende de vários fatores, tipo do lodo do reator, carga orgânica volumétrica, altura do reator e tempo de detenção hidráulica. Entretanto, um valor médio aceito na literatura está na faixa de 0,5 e 0,7 m/h, e como valor de pico $1,5 \mathrm{~m} / \mathrm{h}$.

Além da velocidade ascendente do fluxo no reator, é necessário manter as

taxas de aplicação e a velocidade de passagem nas aberturas do decantador. $\mathrm{Na}$ Tabela 1 e 2 são apresentados os respectivos valores. (Chernicaro et al - 1999) 
Tabela 1 - Taxas de aplicação superficial e tempos de detenção hidráulico no compartimento de decantação do reator UASB.

\begin{tabular}{lcc}
\hline \multicolumn{1}{c}{ Vazão Afluente } & $\begin{array}{c}\text { Taxa de aplicação } \\
\text { Superficial }(\mathrm{m} / \mathrm{h})\end{array}$ & $\begin{array}{c}\text { Tempo de detenção } \\
\text { hidráullico }(\mathbf{h})\end{array}$ \\
\hline Vazão Média & $0,6-0,8$ & $1,5-2,0$ \\
\hline Vazão Máxima & $<1,2$ & $>1,0$ \\
\hline Picos Temporários * & $<1,6$ & $>0,6$ \\
\hline
\end{tabular}

(Chernicaro et al - 1999)

* Picos de vazão com duração entre 2 e 4 horas.

Tabela 2 - Velocidades nas aberturas (passagens) para o decantador do reator UASB.

\begin{tabular}{lc}
\hline Vazão Afluente & Velocidade $(\mathrm{m} / \mathrm{h})$ \\
\hline Vazão Média & $<2,0-2,3$ \\
\hline Vazão Máxima & $<4,0-4,2$ \\
\hline Picos Temporários $*$ & $<5,5-6,0$ \\
\hline
\end{tabular}

(Chernicaro et al - 1999)

* Picos de vazão com duração entre 2 e 4 horas.

Para garantir um bom funcionamento do decantador, é necessário seguir algumas diretrizes básicas:

- As paredes do decantador devem sempre apresentar uma inclinação superior à $45^{\circ}$. Idealmente $>50^{\circ}$.

- A profundidade do compartimento de decantação deve estar na faixa de 1,5 a $2,0 \mathrm{~m}$. 
Tem-se que mantendo as taxas de aplicação e velocidades apresentadas nas Tabelas 1 e 2, garante-se uma boa separação do biogás do líquido, antes de atingir o decantador, e a velocidade na passagem permitindo o retorno do lodo ao manto do reator. (Chernicaro et al - 1999)

\subsection{Tratamento Aeróbio}

O processo de digestão aeróbia da matéria orgânica e nitrogênio reduzido presentes nos esgotos domésticos é realizado através de processos oxidativos, tendo como figuras principais as bactérias heterotróficas e autotróficas, dentre muitos microorganismos, como micrometazoários, ciliados livre - natantes, ciliados pedunculados etc.

As bactérias heterotróficas se incumbem da matéria orgânica, tendo como resultado final energia, gás carbônico, água e novas células. Estas bactérias têm um metabolismo veloz e muito eficiente, se agregando em pequenos flocos, de forma que enquanto houver matéria orgânica e oxigênio dissolvido, elas prevalecem sobre as outras, no caso, as autotróficas. (van Haandel \& Marais, 1999)

As bactérias autotróficas são incapazes de utilizar como fonte de carbono, a matéria orgânica, usando então, o gás carbônico $\left(\mathrm{CO}_{2}\right)$ dissolvido na água como fonte de carbono para suas funções vitais, que se apresenta em equilíbrio na forma de bicarbonato $\left(\mathrm{HCO}_{3}{ }^{-}\right)$e também carbonato $\left(\mathrm{CO}_{3}{ }^{2-}\right)$, para este último se o $\mathrm{pH}$ estiver em torno de 8 . No entanto, para processar este carbono na forma mineral é necessário energia.

Esta energia é retirada da oxidação de nitrogênio amoniacal $\left(\mathrm{NH}_{3}\right)$ já presente nos esgotos sanitários e os gerados pela digestão de material orgânico nitrogenado pelas heterotróficas, proteínas, por exemplo, que também gera nitrogênio amoniacal. De fato, esta oxidação ocorre em duas etapas:

$\left.1^{\mathrm{a}}\right)$ Oxidação pelas nitrossomonas sp do nitrogênio amoniacal à nitrito $\left(\mathrm{NO}_{2}{ }^{-}\right)$;

$2^{\mathrm{a}}$ ) Oxidação pelas nitrobacter $s p$ do nitrito à nitrato $\left(\mathrm{NO}_{3}{ }^{-}\right)$. 
Neste processo também ocorre um consumo de alcalinidade, pois durante a síntese ocorre a absorção de $\mathrm{HCO}_{3}{ }^{-}$, podendo levar à queda de $\mathrm{pH}$ no reator aeróbio. Quando isto acontece e o $\mathrm{pH}$ se encontra próximo a 5, o processo é inibido e a nitrificação cessa.

Os outros microorganismos, maiores, mantém o equilíbrio do ecossistema aeróbio, como os predadores de floco, e alguns participando também da limpeza da água, reduzindo a turbidez, como é o caso por exemplo, dos ciliados pedunculados.

Existem vários sistemas de tratamento baseados na digestão (oxidação) aeróbia, como por exemplo: lagoa aerada, filtro biológico percolador, filtro biológico aerado submerso, biodisco, lodos ativados em suas diversas variantes etc.

No presente trabalho, o sistema de tratamento por lodos ativados é o centro de estudo.

\subsection{Sistemas de Lodos Ativados}

O sistema de lodos ativados tem sido usado para tratamento de esgotos brutos e decantados há quase um século na sua forma convencional (apenas remoção de matéria orgânica e nitrificação) e, há algumas décadas nas suas variantes para remoção de nutrientes nitrogênio e fósforo.

De maneira bem simplificada, o princípio do tratamento por lodos ativados pode ser descrito da seguinte forma: mistura-se o esgoto com uma biomassa suspensa (bactérias principalmente) na forma de pequenos flocos já desenvolvida no reator e insere-se ar. A partir daí, começa a digestão aeróbia da matéria orgânica proveniente do esgoto, que resulta, como já citado anteriormente, em quatro produtos: energia, $\mathrm{CO}_{2}, \mathrm{H}_{2} \mathrm{O}$ e novos microorganismos. Após o tempo necessário para que haja a digestão, ainda é necessário separar a água tratada da biomassa. Para tal, faz-se uso de um decantador, do qual é retirada a biomassa por sedimentação. Esta então é devolvida na maior parte ao reator, conseguindo-se então, por este processo, manter uma alta concentração de microrganismos no reator, o que é a chave para a alta eficiência e velocidade no tratamento.(figura 04) 
Durante este processo de digestão ocorre outro processo, chamado de biofloculação. Este processo se refere ao fato de que as bactérias procuram um meio suporte para aderir, e os sólidos em suspensão do esgoto a ser tratado serve como tal. Assim, elas aderem a este material em suspensão tornando-o mais denso, juntando-o à biomassa. Desta forma, este é sedimentado juntamente com a biomassa no decantador secundário. No reator biológico, a fração destes sólidos que é biodegradável, será digerida lentamente e a que não é, permanece aderida aos flocos.

A formação dos flocos não ocorre apenas com a aderência em sólidos suspensos vindos do afluente. As bactérias presentes na biomassa são capazes de gerar uma matriz gelatinosa, fazendo com que se aglutinem, formando também um suporte para outros microorganismos maiores, tais como os ciliados pedunculados. Esta gelatina é formada principalmente por polissacarídeos excretados pelas bactérias com esta finalidade.(Von Sperling, M. - 1997)

A biomassa que retorna ao reator é o que dá o nome de lodos ativados a este processo, pois esta já está adaptada ou "ativada" para o tipo de esgoto afluente ao reator. Isto significa que as bactérias que se desenvolveram neste meio são justamente aquelas que têm a habilidade de digerir o tipo de matéria orgânica proveniente do esgoto afluente ao reator.

Os microrganismos presentes nesta biomassa são inúmeros, de bactérias até anelídeos e nematóides. Porém, os que prevalecem em quantidade e atividade são as bactérias hetertróficas e autotróficas (para esta última, quando há nitrificação no sistema). 


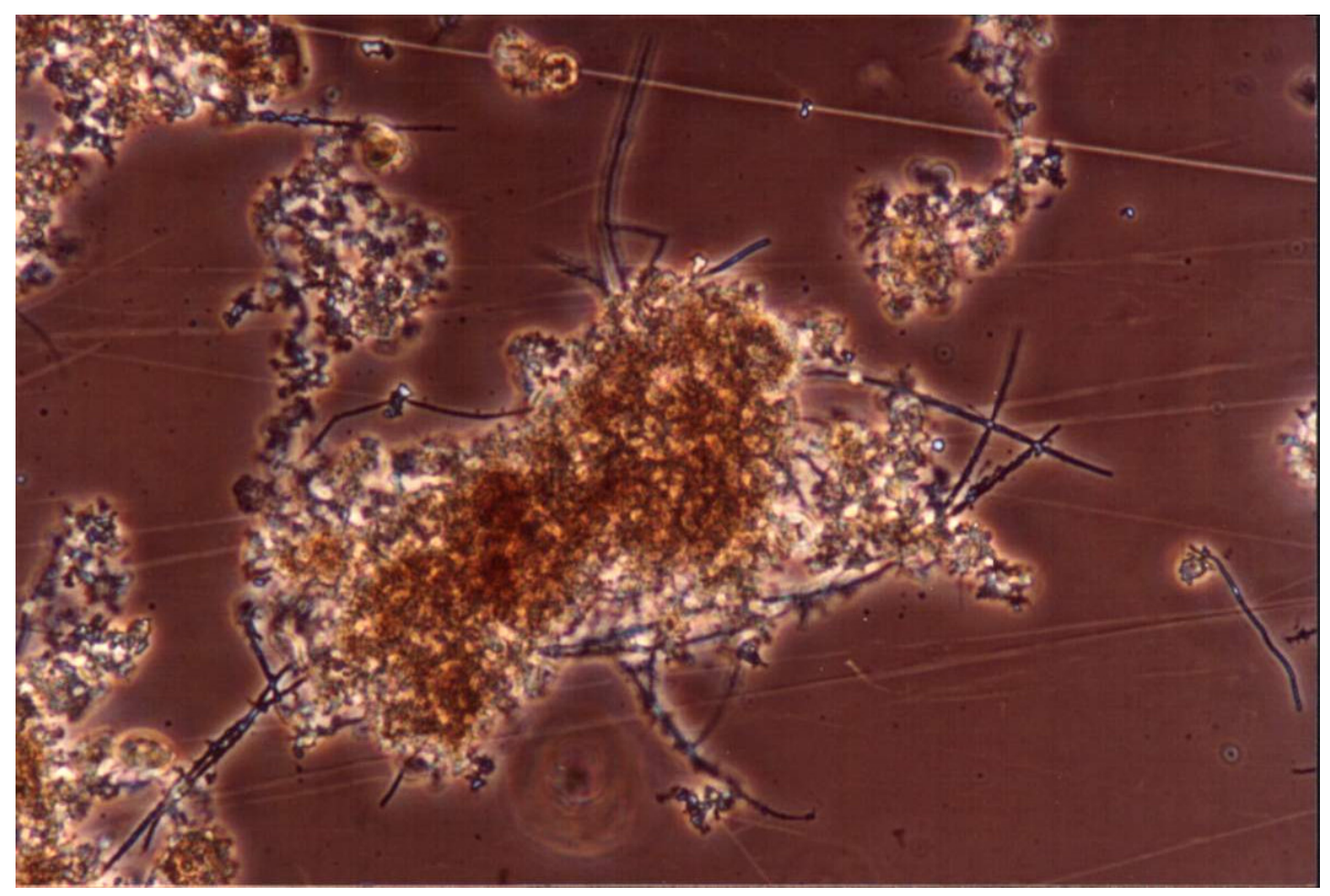

Foto 1 - Floco Biológico de Lodos Ativados "Aberto" - Cortesia Sabesp - ETE Barueri.

Há entre as bactérias num sistema de lodos ativados, dois tipos morfológicos de que devem ser ressaltadas: as formadoras de flocos e as filamentosas. $O$ equilíbrio entre estes dois tipos é que resultará numa boa qualidade do floco biológico (Foto 1). Quando há um maior crescimento das filamentosas, por exemplo, existe a tendência a ocorrer um fenômeno que é conhecido como intumescimento ("bulking”) filamentoso, que nada mais é do que a formação de um floco com péssima sedimentabilidade, pois se apresenta inchado, devido ao comprimento extenso dos filamentos, que em não sendo acompanhado pelo crescimento das formadoras de flocos, deixam muito espaço entre os filamentos, dando ao mesmo uma baixa densidade (Foto 2). Esta formação, pode ser tal que, o lodo não se separa mais do efluente tratado, condição na qual o sistema de tratamento fica completamente comprometido. 


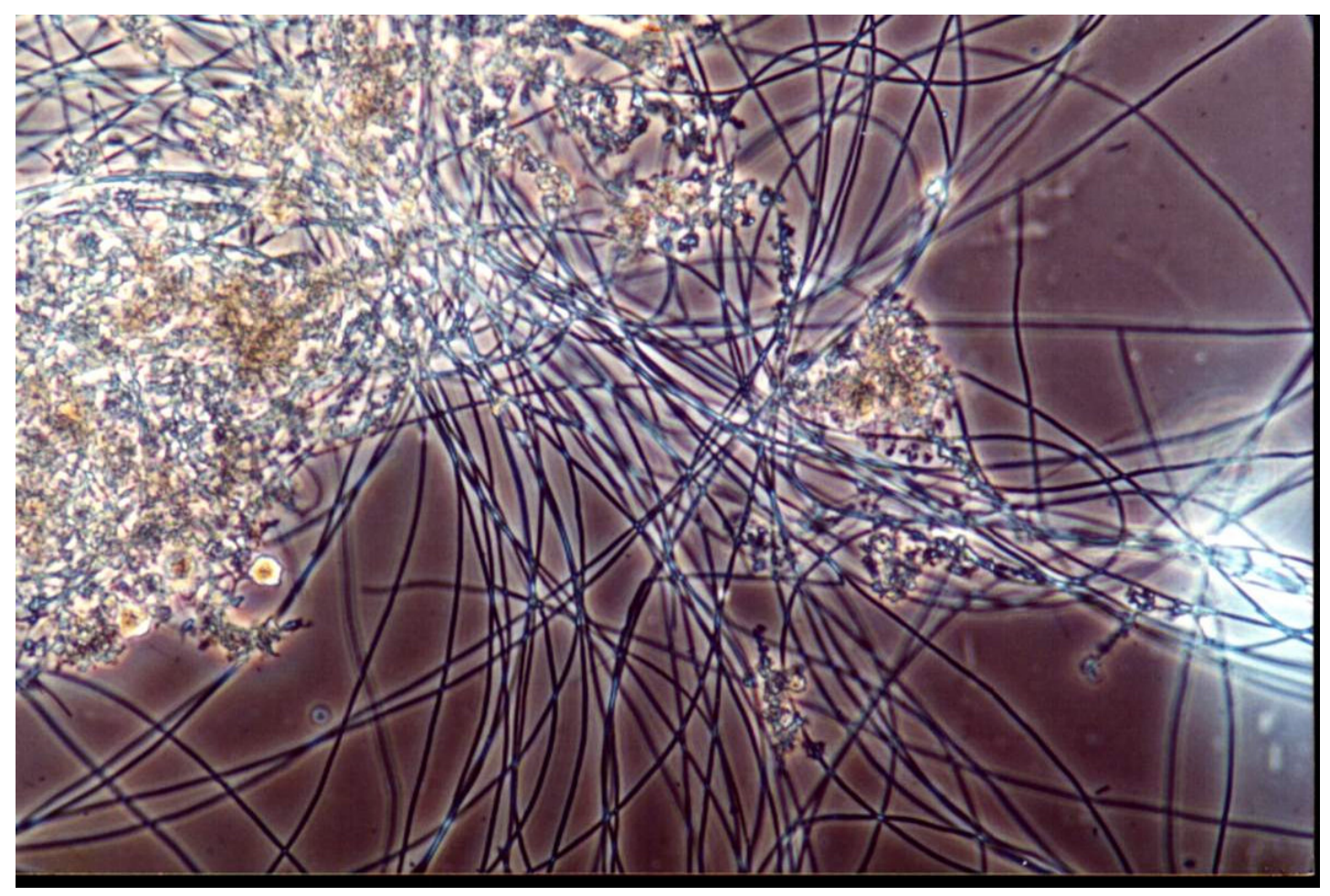

Foto 2 - Floco Biológico de Lodos Ativados "Filamentoso" - Cortesia Sabesp ETE - Barueri.

As razões para estes desequilíbrios são diversas, tanto por características do afluente, altas concentrações de sulfetos, por exemplo, como por características operacionais, tais como relação A/M muito baixa. (Von Sperling, M. - 1997)

Este fenômeno é extensamente discutido na literatura, sendo aqui citado devido à sua importância, contudo, não será detalhado por não ser o escopo deste trabalho.

A quantidade de biomassa que pode se manter no reator (ou tanque de aeração - Foto 3) é dependente da capacidade do decantador secundário (no caso de um sistema em batelada, o próprio reator) em separar a biomassa do efluente tratado e da capacidade do sistema de aeração do reator; pois quanto maior a quantidade de biomassa ativa, maior é o consumo de oxigênio por unidade de volume, afetando diretamente o sistema de aeração. Além disto, os sólidos em suspensão no reator interferem na transferência de oxigênio para o líquido. 


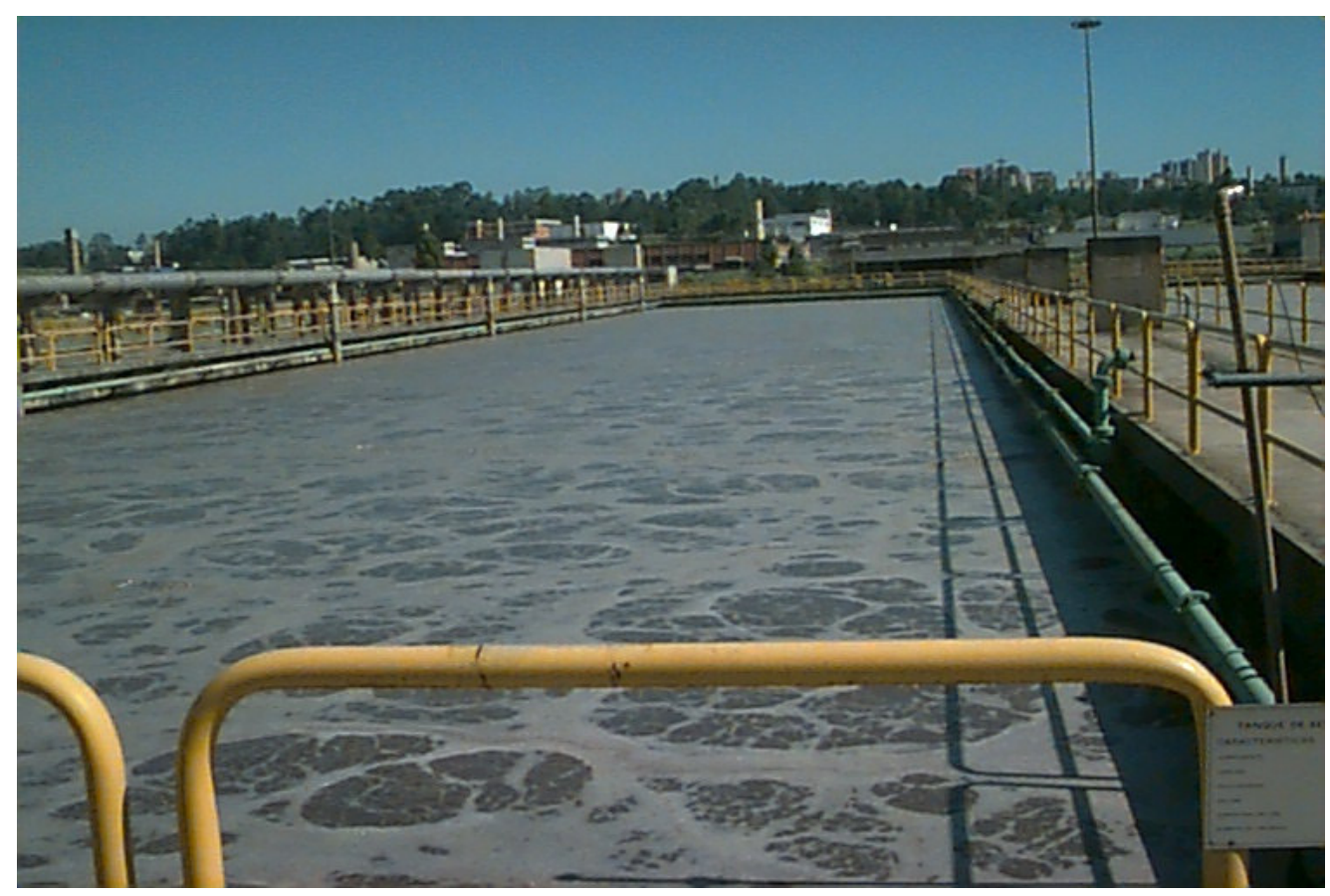

Foto 3 - Tanque de Aeração por Ar Difuso - Cortesia Sabesp - ETE - Barueri.

As formas de se medir a biomassa do sistema são através dos sólidos suspensos voláteis, que em teoria são na sua maior parte matéria orgânica, ou através da DQO. Todavia, estas duas medidas não são precisas no que tange à quantidade de microrganismos, pois não diferem o que é matéria orgânica oriunda do afluente e resíduo endógeno que são inertes, da matéria orgânica que constitui os microrganismos vivos.

Como existe o crescimento microbiano mais o acúmulo de sólidos em suspensão originários do esgoto afluente, se torna óbvia a necessidade de remover parte da biomassa do sistema. Este procedimento é denominado descarte de lodo. A quantidade de massa retirada do sistema por dia em relação à massa total do sistema é um parâmetro conhecido como "Idade do Lodo" ou Tempo de Retenção de Sólidos (TRS, Rs ou $\theta_{\mathrm{c}}$ ), calculado em dias:

$\theta c=\frac{M t}{M d}$

onde

$\theta_{c}=$ Idade do Lodo (ou TRS) em dias 
$M t=$ massa total de lodo no sistema em $\mathrm{kg}$

$M d=$ massa de lodo descartada do sistema em $\mathrm{kg} / \mathrm{dia}$

Um outro conceito muito usado é o da relação Alimento/Microorganismo (A/M). O significado deste parâmetro é o da quantidade de carga orgânica que se aplica à biomassa por dia, dada em kg DBO/ kg SSV. dia.

A descrição dada é a de um sistema de lodos ativados convencional, onde o tratamento é focado na remoção de matéria orgânica (expressa em DBO ou DQO) e sólidos suspensos, cuja seqüência pode ser observada na figura 04. No sistema convencional, a idade do lodo encontra-se na faixa de 4 a 10 dias e A/M de 0,3 a 0,8.(von Sperling 1997)

Nesta configuração a predominância é das bactérias heterotróficas, que são as que digerem a matéria orgânica. As autotróficas, ou seja, bactérias que usam como fonte de carbono o $\mathrm{HCO}_{3}{ }^{-}$têm um crescimento bem mais lento. Estas retiram energia através da oxidação de nitrogênio amoniacal presente no esgoto ou do nitrito formado na primeira etapa, para sua manutenção. Contudo, segundo a literatura, em climas quentes, com $\mathrm{Q}_{\mathrm{C}}>4$ dias, é quase impossível não haver crescimento significativo destas bactérias, resultando no efeito conhecido como nitrificação. (van Haandel \& Marais - 1999)

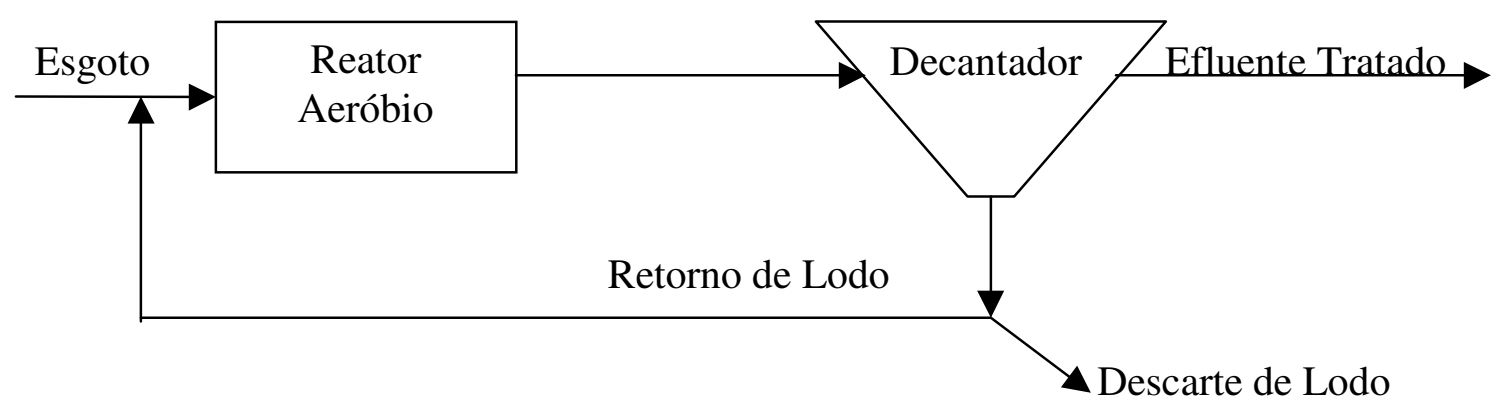

Figura 4 - Esquema de um sistema de lodos ativados convencional. 
Como já comentado, uma das limitações da operação de um sistema de lodos ativados é a concentração de sólidos suspensos no reator, pois este é um fator limitante no processo de sedimentação posterior, usado para separar o lodo do efluente tratado (Foto 4 e 5).

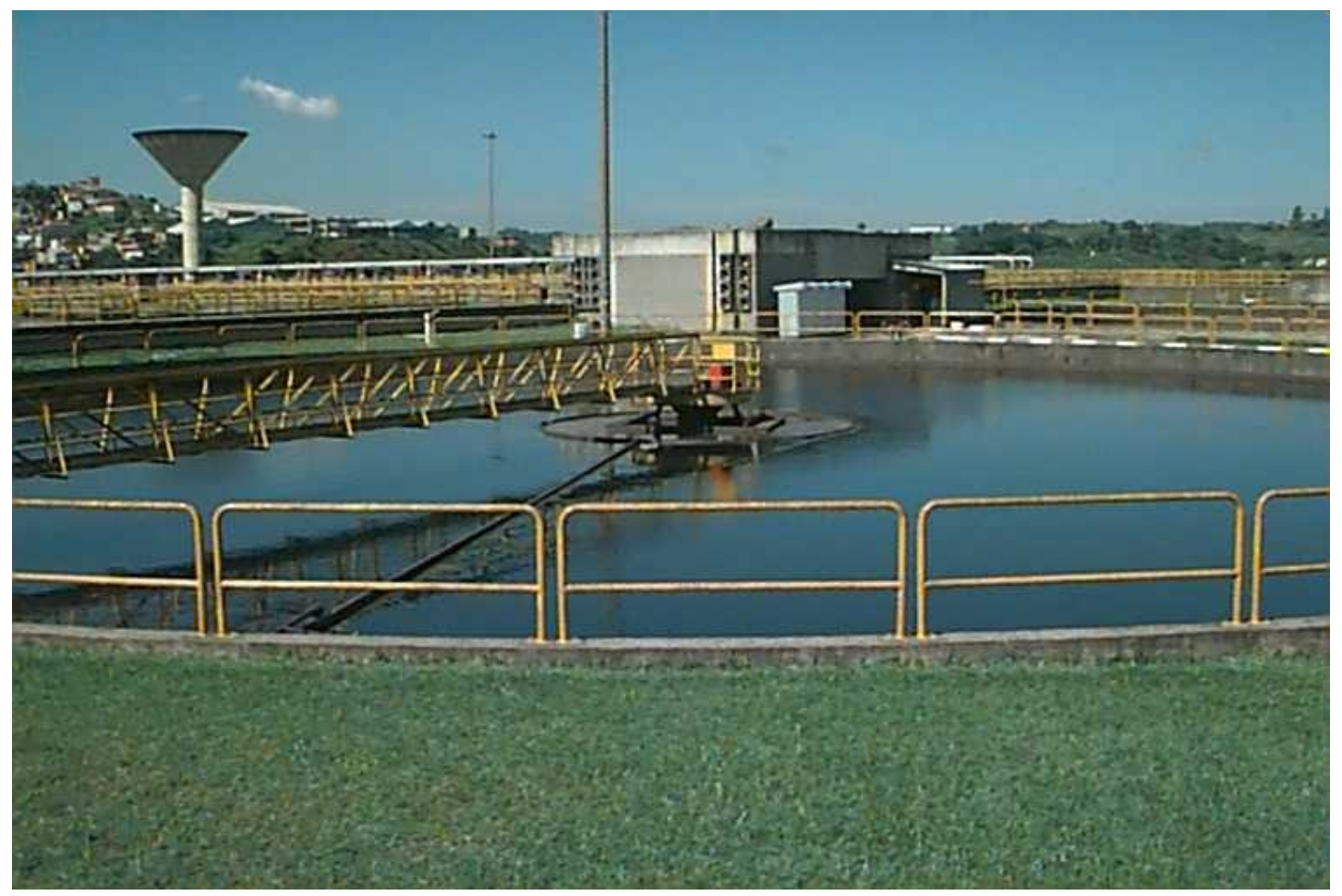

Foto 4 - Decantador Secundário Circular - Cortesia Sabesp - ETE - Barueri.

Verifica-se então que a relação A/M e a Idade do Lodo $\left(\theta_{c}\right)$ estão intimamente ligadas e que as concentrações de sólidos suspensos totais e voláteis no reator são parâmetro de projeto e controle destes sistemas.

Há inúmeros estudos na literatura correlacionando $\theta_{c}$ e relação $\mathrm{A} / \mathrm{M}$ à eficiência no processo de Lodos Ativados. Demonstrou-se que quando a idade do lodo é maior que 3 dias, ou seja, a fração de lodo descartada do sistema por dia é um terço da massa total do sistema, a eficiência de remoção de matéria orgânica é praticamente a mesma para todas as idades adotadas, sob uma mesma relação A/M. (Alem Sobrinho, P. - 1983) 


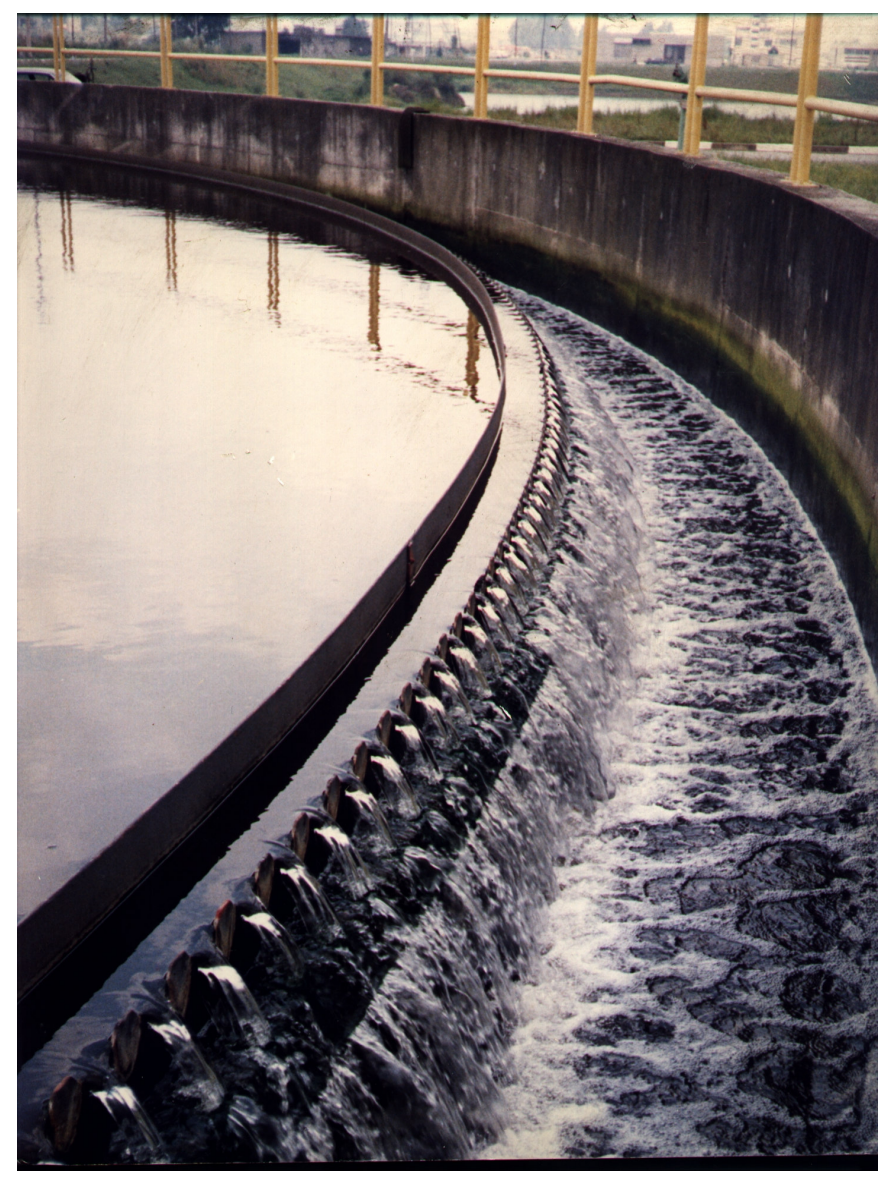

Foto 5 - Vertedouro do Decantador Secundário - Cortesia Sabesp - ETE - Barueri.

Quanto à relação A/M, a interferência no processo se dá pela qualidade do lodo gerado no mesmo. Quando a relação A/M é alta, ou seja, segundo a literatura $\mathrm{A} / \mathrm{M}>0,6 \mathrm{~d}^{-1}$, o lodo tende à desfloculação. Quando é mais baixa, ou seja abaixo de $0,3 \mathrm{~d}^{-1}$, o lodo pode apresentar um crescimento desequilibrado de filamentosas, levando até ao intumescimento. Como a eficiência no processo de lodos ativados depende também e muito da capacidade do sistema separador de fases sólido líquido, em outras palavras, quando o lodo tende a um destes extremos, o sistema de decantação apresenta uma eficiência menor, prejudicando então a eficiência global do sistema.

Por outro lado, sendo que existe uma fração orgânica particulada não biodegradável, volátil portanto, que irá se agregar e fazer parte da medida de sólidos voláteis juntamente com o resíduo endógeno gerado do decaimento celular, verificase que o total de sólidos voláteis num reator não representa o total de lodo ativo. 
Posto que o parâmetro normalmente usado, como medida da quantidade de biomassa, são os sólidos suspensos voláteis no reator, e como já citado, que a concentração da biomassa ativa é variável em cada sistema, pois depende das características do esgoto afluente, é plausível afirmar que, o comportamento de cada sistema em relação a $\mathrm{A} / \mathrm{M}$ será característico dele mesmo.

Existe uma relação entre $\theta_{\mathrm{c}}, \mathrm{A} / \mathrm{M}$ e SSV proposta na literatura (Marais \& Ekama - 1976), através da qual é possível estimar a fração de biomassa ativa, assim como a metodologia para determinar esta fração. Este método, com suas equações, é detalhado no capítulo 4.0 - Material e Métodos.

Para determinar a quantidade de massa gerada pelo crescimento da biomassa no sistema, é introduzido o conceito do coeficiente de síntese celular Y, que é a relação de rendimento da biomassa, ou em outras palavras, a relação da quantidade de novas células formadas medidas em sólidos suspensos voláteis em relação à quantidade de matéria orgânica consumida em DQO (ou DBO) por dia. Logo, sua

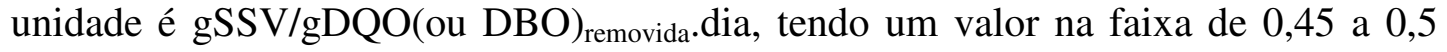
com base em DQO removida (van Haandel \& Marais - 1999).

Pode-se expressar a variação de biomassa em função do coeficiente Y através da seguinte equação:

$\frac{d X v}{d t}=Y \bullet \frac{d S}{d t}$

onde:

$X v=$ concentração de sólidos suspensos voláteis no reator em $\mathrm{gSSV} / \mathrm{m}^{3}$

$S=$ concentração do substrato em $\mathrm{gDBO}$ ou $\mathrm{gDQO} / \mathrm{m}^{3}$

$Y=$ coeficiente de rendimento em $\mathrm{gSSV} / \mathrm{g}(\mathrm{DBO} \text { ou DQO })_{\text {removida.dia }}$

$t=$ tempo em dias 
Sendo o coeficiente Y uma variável estequiométrica, usada nos modelos matemáticos para Lodos Ativados, a avaliação cinética na modelagem é feita através do coeficiente (taxa) de crescimento específico $\mu$, que varia em função da concentração do substrato. Isto porque a disponibilidade do alimento é um dos fatores limitantes para o crescimento das bactérias. Quando o substrato está em excesso, as bactérias o consumirão na sua taxa máxima de crescimento, a qual é

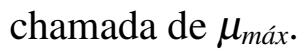

Para determinar-se então a variação de concentração de sólidos suspensos voláteis, através de $\mu$, pode-se usar a seguinte expressão:

$\frac{d X v}{d t}=\mu . * X v$

onde:

$X v=$ concentração de sólidos voláteis no reator em $\mathrm{gSSV} / \mathrm{m}^{3}$

$\mu=$ taxa de crescimento específica em $\operatorname{dia}^{-1}$

$t=$ tempo em dias

Através de estudos com culturas bacterianas, Monod apresentou uma relação entre a taxa de crescimento específica máxima e concentração do substrato. A fórmula empírica que ele obteve é (von Sperling 1997):

$\mu=\mu_{\text {máx. }} \frac{S}{K s+S}$

onde:

$\mu_{\text {máx }}=$ taxa de crescimento específico máxima em $\operatorname{dia}^{-1}$

$S=$ concentração do substrato (limitante) em $\mathrm{gDBO} / \mathrm{m}^{3}$ 
$K s=$ constante de saturação, definida como a concentração de substrato quando $\mu=\mu_{\text {máx }} / 2$ em gDBO $/ \mathrm{m}^{3}$

Com estas equações pode-se predizer quanto a biomassa cresce através da metabolização da matéria orgânica. Entretanto, este não é o resultado final dentro de um reator aeróbio. Isto porque existe uma parte desta biomassa que morre, decrescendo, portanto, a concentração de sólidos suspensos voláteis no reator.

Para determinar o quanto se perde de biomassa, introduz-se o conceito do coeficiente de decaimento (ou mortandade) $b$. Este coeficiente assim como $\mu$ e $\mu_{m a ́ x}$, também se refere ao equacionamento da cinética do sistema de lodos ativados.

$\frac{d X}{d t}=-b * X$

$X_{b}=$ concentração de sólidos voláteis biodegradáveis (biomassa) em mgSSV/L $b=$ coeficiente de decaimento em $\operatorname{dia}^{-1}$

A partir destas equações, pode-se definir que a variação da quantidade de biomassa gerada no sistema durante a degradação da matéria orgânica biodegradável, como segue:

$\frac{d X v}{d t}=\mu * X v-b * X_{b}(11) \quad$ ou $\quad \frac{d X V}{d t}=Y * \frac{d s}{d t}-b * X_{b}$ 
Usando a equação para um tempo finito temos:

$$
\frac{\Delta X}{\Delta t}=Y * \frac{\Delta S}{\Delta t}-b * X_{b}
$$

Um outro fator a ser considerado é a temperatura. Este parâmetro interfere diretamente nos coeficientes cinéticos de qualquer reação química ou bioquímica, interferindo então, no sistema de lodos ativados.

Em geral, a maioria das reações químicas e biológicas, aumentam em função do aumento da temperatura. Em reações biológicas ou bioquímicas, entretanto, o comportamento é diferenciado. Normalmente percebe-se uma mesma ascensão da velocidade de reação com o aumento da temperatura, porém, até um certo valor. Isto provavelmente se deve ao fato de que, a partir de uma dada temperatura, ocorra a degradação das enzimas ou outras substâncias orgânicas envolvidas na reação. Em resumo, a velocidade de reação normalmente aumenta com a subida da temperatura do meio, até um certo valor ótimo e depois decresce.

Os microrganismos são também classificados pela faixa de temperatura que melhor se desenvolvem, que no caso dos lodos ativados, é a faixa Mesofílica, ou seja, de 4 a $30^{\circ} \mathrm{C}$. Consta ainda na literatura, que em termos de eficiência, sistemas com idade de lodo alta, tal como lodos ativados por aeração prolongada, tem pouca alteração de eficiência em função da temperatura, no que tange a remoção de carga orgânica. Os sistemas de lodos ativados convencional também parecem sofrer pouca influência. Tal comportamento provavelmente se deve fato de que, geralmente uma grande parte da carga orgânica biodegradável, está sob a forma particulada, que é absorvida pelo floco biológico e metabolizada lentamente. (von Sperling - 1997)

A influência da temperatura para estes fatores cinéticos, que é encontrada na literatura, obedece o seguinte equacionamento:

$$
K_{t}=K_{20} * \theta_{t}^{(t-20)}
$$


Onde:

$K_{t}=$ constante cinética de reação à uma temperatura " $\mathrm{t}{ }^{\circ} \mathrm{C}$ "

$K_{20}=$ constante cinética de reação à temperatura de $20^{\circ} \mathrm{C}$

$\theta_{t}=$ coeficiente de temperatura

$t=$ temperatura no meio $\left({ }^{\circ} \mathrm{C}\right)$

Os valores para $\theta_{t}$ para uso em modelos matemáticos, são difíceis de determinar em locais de clima temperado, onde a variação de temperatura entre inverno e verão são bem significativas.

No caso do Brasil, por exemplo, este fenômeno é bem mais ameno, pois as temperaturas nos líquidos não se distanciam muito dos $20^{\circ} \mathrm{C}$, temperatura na qual normalmente os parâmetros cinéticos são apresentados. (von Sperling - 1997)

Até este ponto, o equacionamento apresentado é útil, se a medida usada para o substrato for a demanda de oxigênio para matéria biodegradável e a biomassa ativa.

Todavia, neste equacionamento não está sendo considerada a matéria orgânica particulada não biodegradável (para um $\theta_{\mathrm{c}}$ característico de lodos ativados) e o resíduo endógeno, os quais se acumulam no lodo. Estes dois conceitos são levados em conta no modelo desenvolvido pela UCT - University of Cape Town (Marais \& Ekama - 1976).

O sistema de equações utilizado neste trabalho, está descrito mais adiante com maior detalhamento. Os conceitos descritos até o momento são verdadeiros para a maioria dos modelos matemáticos de lodos ativados, sendo que no trabalho dos pesquisadores da UCT, eles são complementados para contemplar as frações que faltam: resíduo endógeno e material orgânico particulado inerte.

A seguir, tem-se uma descrição dos principais modos de operação de um sistema de lodos ativados em relação ao comportamento hidráulico.

Assim como apresentado no item 3.2 sobre reatores anaeróbios, o sistema de Lodos Ativados, também pode operar de duas formas: 
- Lodos Ativados em Fluxo Contínuo

- Lodos Ativados em Fluxo Intermitente ou Batelada

Na figura 04 é apresentado o esquema básico de um sistema de Fluxo Contínuo. Neste sistema o reator é alimentado continuamente com o afluente a ser tratado e com o lodo retirado do decantador, que por sua vez também é alimentado continuamente com o conteúdo do reator. A razão de recirculação está na faixa de 0,6 a 1,2 da vazão afluente para sistemas convencionais. (von Sperling - 1997)

O sistema em Batelada funciona em etapas: primeiro alimenta-se o reator com o esgoto afluente mais o Lodo Ativado. Após o enchimento do reator, mantém-se aerando a mistura por um tempo pré - determinado. Ao término deste tempo, cessase a aeração e o reator é drenado para um decantador ou usa - se o próprio reator como decantador, mantendo-o sem agitação e permitindo que o lodo sedimente e retirando por cima o efluente tratado e decantado. A não ser que se faça uso de um tanque de equalização à montante do reator, este sistema exige pelo menos dois reatores em paralelo, sendo que enquanto um está em aeração ou sedimentando o outro está sendo alimentado. A Figura 5 apresenta um esquema deste tipo de operação.

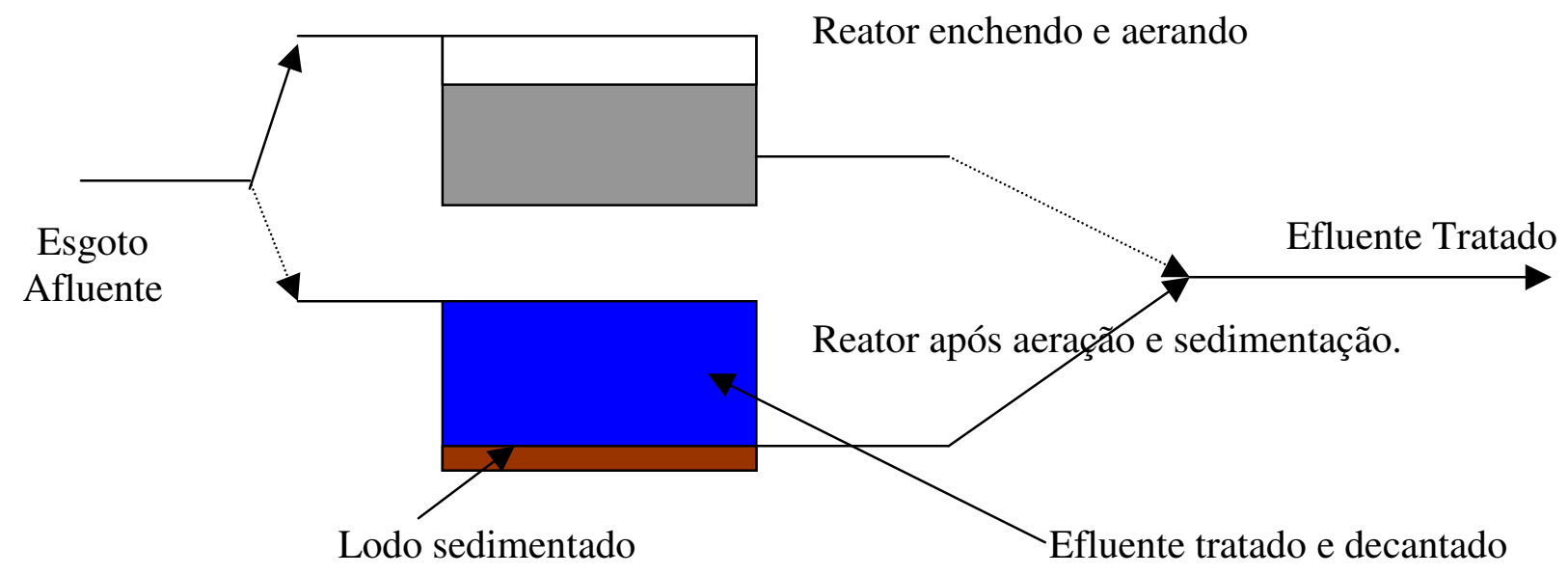

Figura 5 - Lodos Ativados em Batelada (adaptado de von Sperling 1997). 
As equações apresentadas até o momento são comuns a todos os modelos matemáticos encontrados na literatura. A escolha do modelo desenvolvido por Marais, G. V. R. \& Ekama, G. A. (1976), para uso no presente trabalho, se prende ao fato deste modelo ser o mais racional entre os modelos já desenvolvidos para o processo de lodos ativados.

\subsubsection{Sistemas de Lodos Ativados com Remoção Biológica de Nutrientes}

Os sistemas de lodos ativados modificados para remoção de nutrientes, podem ser estruturados para a remoção biológica de fósforo, nitrogênio ou ambos. Estes apresentam uma diferença na configuração de reatores, pois são adicionados reatores não aerados, em série com o reator aeróbio. O que segue é um resumo destes sistemas citados apenas para ressaltar a importância da parcela rapidamente biodegradável, quando há a intenção de se usar num projeto uma configuração deste tipo.

O primeiro sistema modificado foi desenvolvido para remoção de nitrogênio. Através de um outro processo biológico conhecido como desnitrificação, que é a redução de nitrato a nitrogênio gás, conforme a reação simplificada:

$$
\mathrm{NO}_{3}{ }^{-}+\mathrm{C} \text { (Matéria Orgânica) Bactérias } \rightarrow \mathrm{CO}_{2}+\mathrm{H}_{2} \mathrm{O}+\mathrm{N}_{2}
$$

Foi citado anteriormente que as bactérias autotróficas oxidam o nitrogênio amoniacal a nitrato. Este nitrato então pode ser reduzido à nitrogênio gás, também pela ação de outras bactérias, heterotróficas facultativas, que na ausência de oxigênio dissolvido e presença de nitrato (condições anóxicas), conseguem se utilizar do nitrato como oxidante da matéria orgânica biodegradável ao invés de usar o oxigênio para o seu metabolismo reprodutivo (anabolismo) e de geração de energia (catabolismo).

Desta forma, para sistemas modificados para a remoção de nitrogênio são utilizados dois reatores em série, um aeróbio e outro anóxico. A ordem destes reatores define seu conceito que pode ser: 
- Pós - desnitrificação

- Pré - desnitrificação, com alta recirculação.

A matéria orgânica que servirá de redutor do nitrato pode ser externa ou do próprio esgoto afluente, sendo preferencialmente utilizada aquela rapidamente biodegradável. Caso em contrário o tempo de detenção necessário no reator anóxico pode ser muito alto, tornando o reator muito grande e inconveniente, pois ele deve possuir um sistema de mistura para manter o lodo em suspensão.

Este é o caso do sistema com pós - desnitrificação, no qual o reator anóxico se encontra depois do reator aeróbio, como mostra a figura 6. Como o esgoto já passou pelo reator aeróbio, a maior parte da matéria orgânica biodegradável já foi consumida, não restando praticamente nada para a desnitrificação. Sendo assim, se torna necessário adicionar uma fonte externa de carbono no reator anóxico, como metanol ou acetatos, que são de rápida metabolização. Uma das vantagens deste processo é que se torna mais fácil de controlar, pois pode ser dosado a matéria orgânica, conforme a necessidade, diferente do esgoto afluente que pode ter variações na quantidade e concentração desta.

A determinação da fração rapidamente biodegradável da matéria orgânica afluente, é um dos objetivos deste trabalho, pois desta forma é possível determinar se há condições de usar o próprio efluente do reator UASB como redutor do Nitrato.

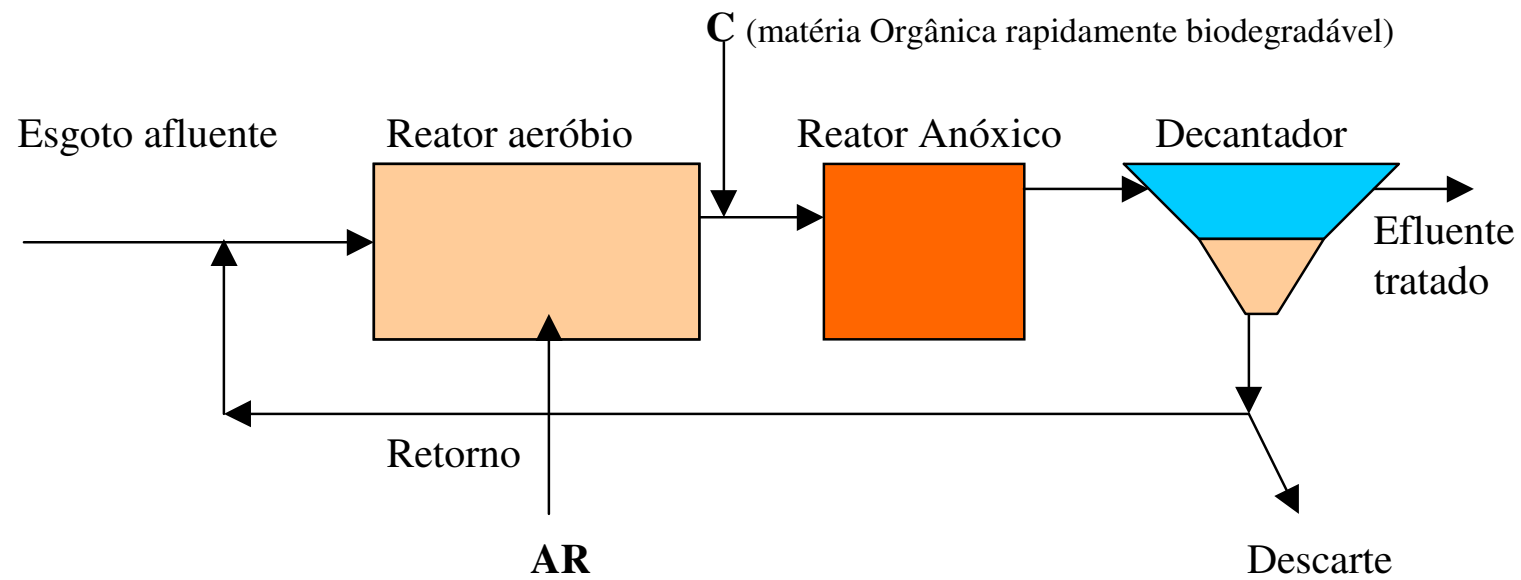

Figura 6 - Esquema de um sistema de pós - desnitrificação. 
Para o uso da matéria orgânica do próprio esgoto afluente ao tratamento, a desnitrificação tem que ocorrer antes da fase aeróbia, ou seja, um sistema com pré desnitrificação. Os sistemas com pré-desnitrificação tem sua seqüência demonstrada na Figura 7.

Nos sistemas com pré - desnitrificação existe uma alteração a mais em relação aos com pós-desnitrificação: uma alta recirculação do reator aeróbio para o anóxico. Isto porque a formação do nitrato ocorre no reator aeróbio, o qual está depois do anóxico nesta configuração, logo é necessário levar o nitrato até o reator não aerado que está recebendo a matéria orgânica rapidamente e mais lentamente biodegradável do esgoto afluente. A vazão aplicada nesta recirculação interna é dependente da concentração de nitrato formado e da concentração de matéria orgânica biodegradável, mas varia normalmente entre uma a três vezes a vazão afluente. Também, deve ser considerada nos cálculos a vazão de recirculação do decantador, que é aproximadamente igual à afluente. Desta forma, a recirculação total para o reator anóxico, está entre duas a quatro vezes a vazão afluente.

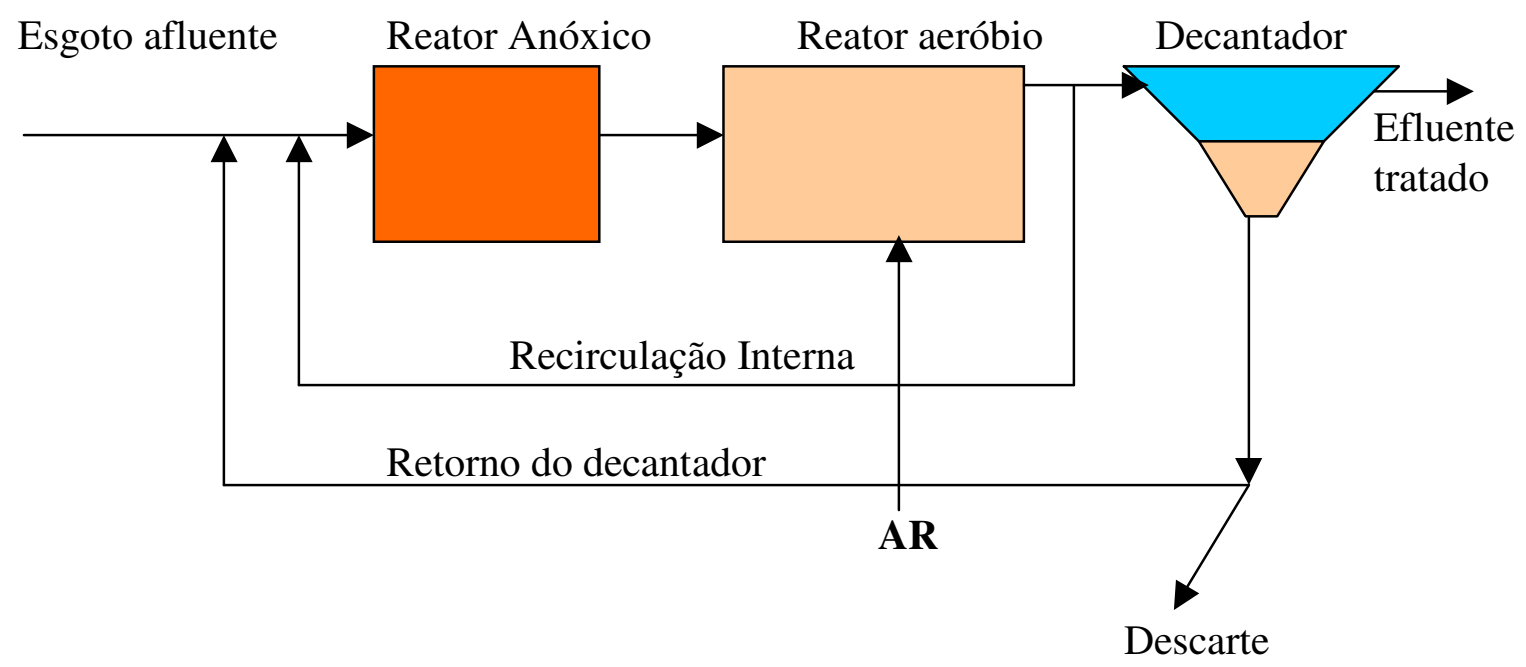

Figura 7 - Esquema de um sistema com Pré - desnitrificação. 
O processo de remoção biológica de fósforo é baseado num fenômeno observado em algumas bactérias heterotróficas facultativas, as quais foram denominadas de "poli - P". Estas bactérias, quando expostas a condições alternadas aeróbias e anaeróbias constantemente, desenvolvem a habilidade de acumular fósforo em excesso às suas necessidades metabólicas, quando em condições aeróbias. O acúmulo é realizado através de um processo de polimerização de íons orto - fosfato dentro da célula. Quando expostas a condições anaeróbias (sem oxigênio e sem nitrato) estas bactérias se utilizam da energia acumulada neste polifosfato para absorver material orgânico rapidamente biodegradável, liberando o fósforo novamente para o meio. Não cabe neste trabalho aprofundar a discussão sobre os mecanismos metabólicos deste processo, e sim a importância deste no dimensionamento de sistemas de tratamento.

A remoção do $\mathrm{P}$ se dá na medida em que se descarta o lodo da fase aeróbia, onde as poli - P absorveram fósforo. O Lodo Ativado normalmente apresenta uma concentração em torno de $2,5 \%$ de $\mathrm{P}$ em massa, enquanto as poli - P podem atingir até $38 \%$. Vale ressaltar que as desnitrificantes, concorrem pelo substrato rapidamente biodegradável com vantagens; logo, se não houver uma condição de fato anaeróbia, as desnitrificantes tendem a se sobressair.

Os sistemas modificados para remoção biológica de fósforo são dotados de um reator anaeróbio antecedendo o aeróbio e também o anóxico se houver remoção de N. Os sistemas mais conhecidos para remoção de fósforo e nitrogênio são o Bardenpho Modificado e o UCT modificado (van Haandel \& Marais, 1999).

A Figura 8 traz os dois sistemas onde se observa que a diferença básica entre os dois é que no sistema UCT modificado evita-se recircular o lodo vindo do reator aeróbio, fazendo uma recirculação do reator anóxico para o anaeróbio. Esta medida faz com que a concentração de nitrato no reator anaeróbio seja tão menor quanto possível, diferente do sistema Bardenpho, que ao recircular o lodo diretamente do decantador para o reator anaeróbio pode levar uma quantidade razoável de nitrato. 
Os esquemas mostrados na Figura 8 são apenas dois de várias configurações usadas para sistemas de remoção biológica de nutrientes. Porém, nestes sistemas está a essência da remoção biológica de nutrientes.

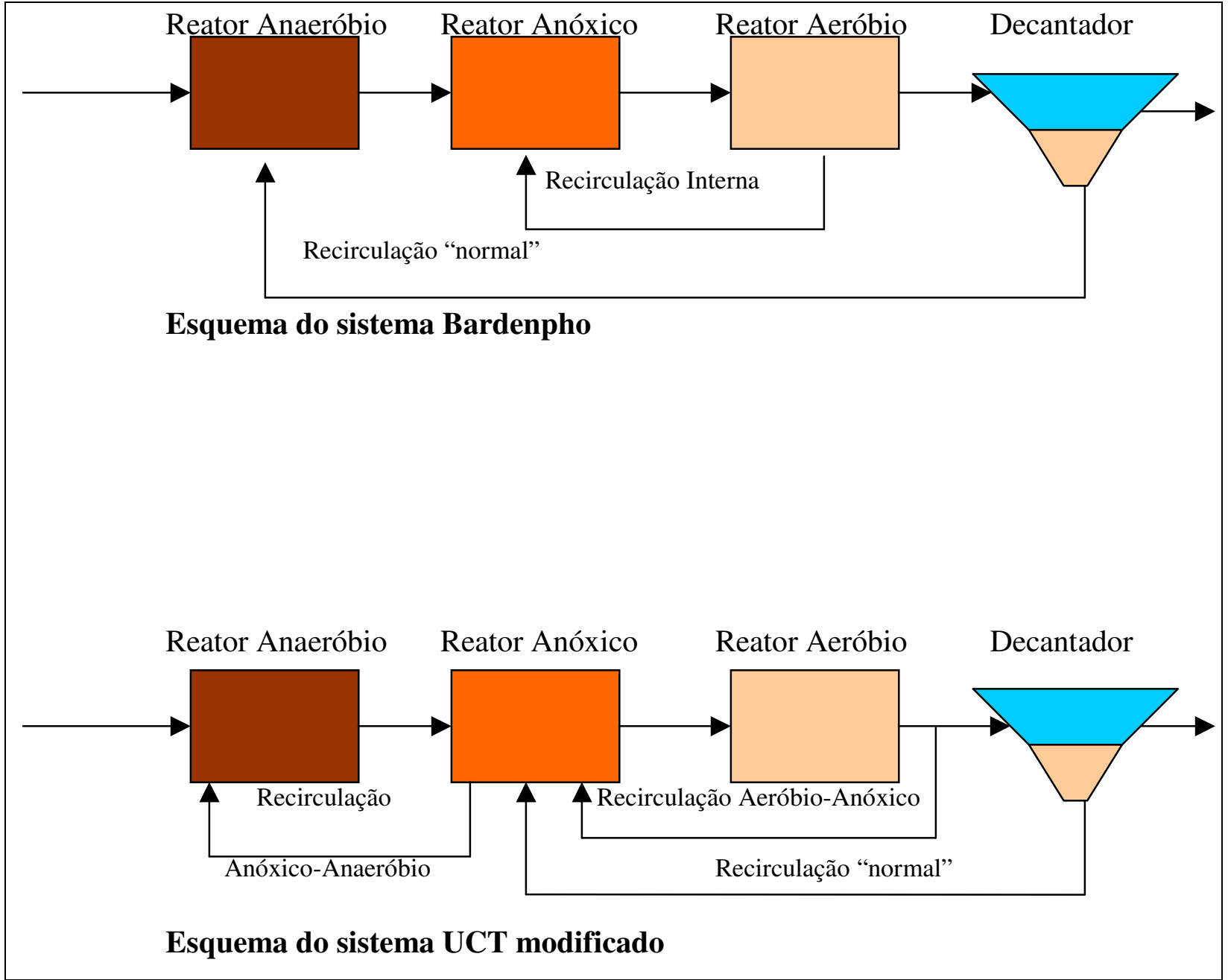

Figura 8 - Sistemas modificados para remoção de nitrogênio e fósforo (adaptado de van Haandel \& Marais - 1999) 


\subsubsection{Fracionamento da Matéria Orgânica Afluente}

Para os cálculos estequiométricos usados no dimensionamento de um sistema de tratamento por lodos ativados, é necessário conhecer a forma como a matéria orgânica do afluente se distribui, em especial a rapidamente biodegradável nos sistemas com remoção de nutrientes, como citado anteriormente. Na figura 9 tem-se uma das representações desta distribuição.

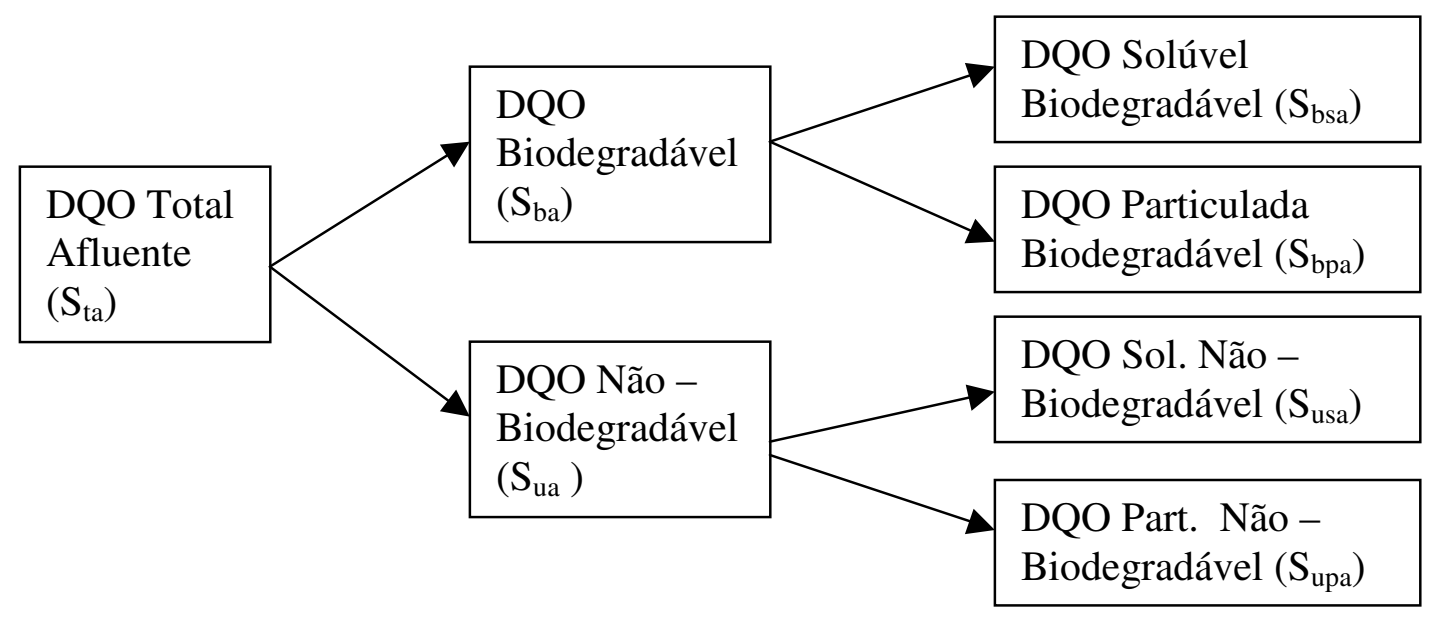

Figura 9 - Fracionamento da matéria orgânica afluente expressa em DQO (van Haandel e Marais, 1999)

Em alguns casos como neste exemplo se considera a matéria orgânica rapidamente biodegradável igual à solúvel biodegradável. Contudo segundo Wentzel, Mbewe e Ekama (1995), a determinação desta por filtração pode apresentar desvios em relação ao determinado experimentalmente por outros meios (técnica que será usada neste trabalho e estará descrita mais adiante), pois podem haver substâncias solúveis $(<0,45 \mu \mathrm{m})$ lentamente biodegradáveis, e que devido a isto a medida mais acurada é obtida com a determinação da taxa de consumo de oxigênio (TCO) em condições específicas.

A fração solúvel não biodegradável é possível de se determinar através da DQO com uma filtração prévia da amostra do efluente tratado de qualquer estação de tratamento que esteja operando em boas condições e "adaptada" ao esgoto em 
questão. Esta fração irá atravessar o sistema de tratamento sem ser afetada, mantendo-se no líquido e consequentemente descartada junto com efluente final.

Parte do lodo presente no reator será composto pela fração particulada não biodegradável da matéria orgânica afluente. Entretanto, a determinação desta só faz sentido quando em regime permanente, pois a ela é feita através das hipóteses do modelo que é em regime permanente. Esta fração é determinada por cálculo, que considera a fração ativa do lodo ativado, a qual é determinada por um processo de digestão aeróbia do lodo e do conhecimento do $\theta c$ deste lodo.(Dold, Ekama e Marais, 1986)

Finalmente, a fração lentamente biodegradável, é determinada por diferença. Todo este fracionamento é medido em DQO, pois como já explicado anteriormente, é uma medida mais segura e mais prática do que a DBO. Mesmo porque, a DBO só mede a fração biodegradável, logo, não é capaz de determinar a massa de material particulado não biodegradável. Ainda, existe uma relação definida experimentalmente entre o SSV da biomassa e a DQO, de SSV / DQO 1,48, confirmada por vários pesquisadores (van Haandel e Marais, 1999).

Quanto à utilização da matéria orgânica biodegradável pelas bactérias, segundo van Haandel e Marais, para esgotos tipicamente domésticos cerca de 1/3 da DQO biodegradável é transformada em energia (catabolismo), resultando também em $\mathrm{CO}_{2}$ e $\mathrm{H}_{2} \mathrm{O}$. Os outros $2 / 3$ são usados para construção de novas células (anabolismo).

Contudo, mesmo a própria biomassa é biodegradável. Sendo assim esta também será digerida dentro do reator, mas não segue exatamente a mesma relação de uso para catabolismo e anabolismo, pois desta biomassa apenas cerca de $80 \%$ é biodegradável. Este resíduo particulado não biodegradável vindo da decomposição celular é chamado de resíduo endógeno. Assim, esta é a segunda fração do lodo ativado que compõe a parte inerte do mesmo.

Concluindo, tem-se então que a carga orgânica afluente medida em DQO, é dividida em duas frações principais: biodegradável e não biodegradável. E quatro subdivisões: fração rapidamente biodegradável, lentamente biodegradável, não 
biodegradável solúvel e não biodegradável particulada. O lodo ativado por sua vez pode ser dividido em três: fração ativa, fração particulada inerte (do afluente) e fração endógena. Estas também são medidas em DQO pelo modelo da UCT, e podem ser convertidas para SSV através de um fator chamado $\mathrm{f}_{\mathrm{cv}}$, o qual relaciona mg DQO/mg SSV e tem como valores aceitos 1,42 a 1,5 (van Haandel \& Marais, 1999). O valor de 1,48 é o mais usual.

Em outros trabalhos na literatura, a fração de matéria orgânica não biodegradável é chamada de refratária, recalcitrante ou de difícil degradação. A distinção feita nestes termos é em função dos sistemas que tratam materiais perigosos ou de difícil biodegradação, que usam um tempo de detenção muito longo, acima de 20 dias (Rosich, Alan F. e Gaudy Jr. A. F. - 1992), onde é favorecida então a biodegradação dos mesmos.

Para um sistema convencional de lodos ativados, tratando esgotos domésticos, onde tempo de detenção na prática é menor, o efeito destas substâncias é o mesmo que se não fossem biodegradáveis.

Uma outra abordagem presente na literatura, (Wentzel MC, Mbewe A. and Ekama, G.A - 1999), mantém praticamente a mesma distribuição da matéria orgânica descrita no início deste item, porém, com maior detalhamento e sofisticação. A figura 11 apresenta o esquema de distribuição medida em DQO, da matéria orgânica afluente segundo estes autores. O que se pode observar de diferente neste fracionamento é que há uma subdivisão do material rapidamente biodegradável, separado em duas frações: ácidos graxos de cadeia curta e materiais orgânicos fermentáveis, por exemplo açucares. Também aparece mais uma subdivisão da DQO total que é a biomassa heterotrófica. Esta última, segundo os autores, tem a sua origem no próprio esgoto, que se desenvolveriam durante o percurso nas tubulações, realizado da origem até a estação de tratamento. 


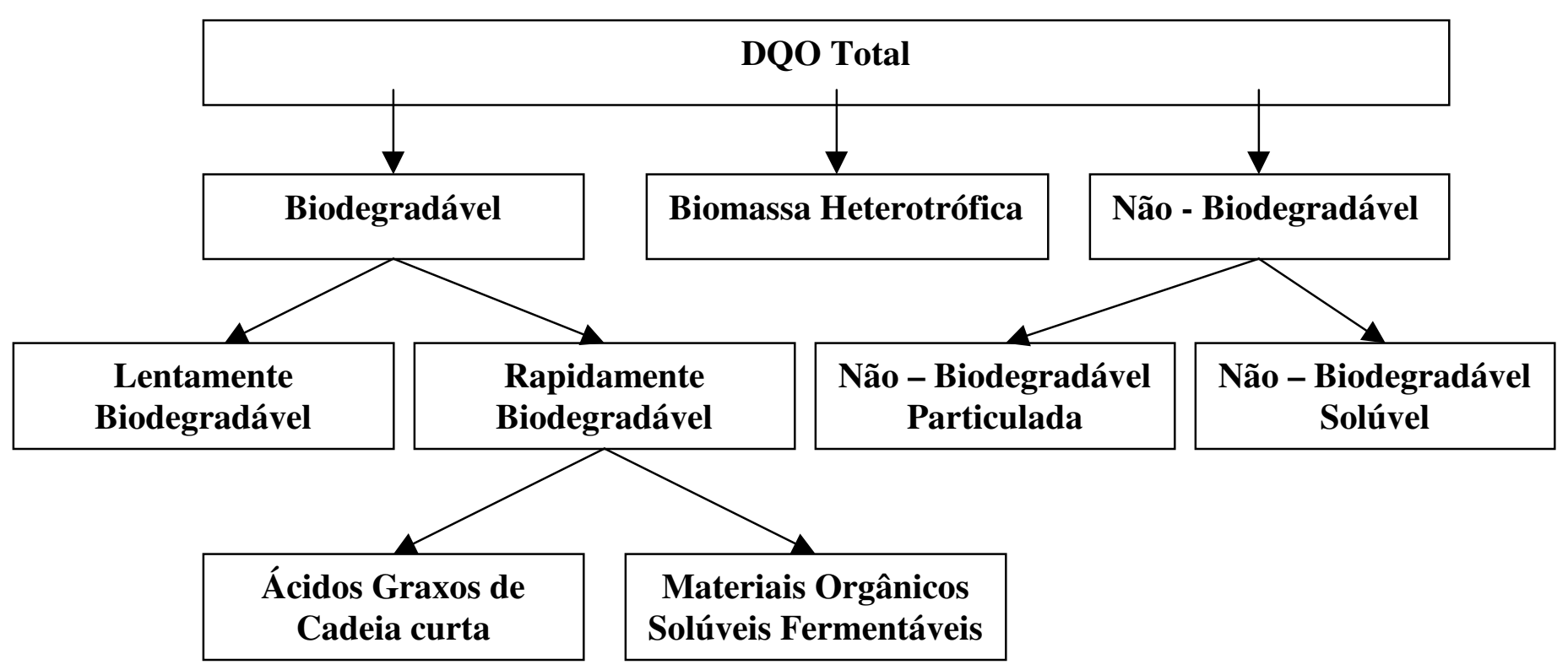

Figura 10 - Distribuição da matéria orgânica afluente - Adaptado de Wentzel MC, Mbewe A. and Ekama, G.A - 1999.

Uma outra abordagem encontrada na literatura é a de Ros, Milenko (1993), onde a matéria orgânica é separada conforme mostrado na Figura 11.

A principal diferença nesta distribuição, é a separação pela solubilidade da matéria orgânica afluente e por uma característica na matéria orgânica solúvel: a possibilidade de adsorção pelo floco biológico/bactéria.

A matéria orgânica é separada inicialmente como solúvel e insolúvel, depois a parte solúvel como adsorvível e não adsorvível, e depois quanto à sua biodegradabilidade. Neste esquema de separação da matéria orgânica afluente, a fração rapidamente biodegradável faz parte da fração solúvel adsorvível.

Em princípio o que parece uma grande diferença, se analisado com mais atenção, não é tão grande. Se for avaliado que, durante o processo de digestão aeróbia da matéria orgânica nesta abordagem, tem-se: uma fração rapidamente biodegradável, uma fração lentamente biodegradável ( adsorvível lentamente biodegradável + insolúvel biodegradável + não adsorvível biodegradável), uma fração solúvel não biodegradável e uma fração particulada inerte (não biodegradável 
insolúvel). Observa-se uma distribuição muito similar à feita por van Haandel A. e Marais G. (1999), onde a lentamente biodegradável é considerada a particulada. É claro que a descrição feita por Ros, Milenko (1993) é mais detalhada, e implica em diferenciar as etapas na cinéticas de metabolização da matéria orgânica. No entanto, dado que a taxa de crescimento específico $\mu$, acaba por ser uma somatória de todos estes efeitos, no momento em que ela é adotada em qualquer que seja o sistema de equações, estes efeitos estarão computados.

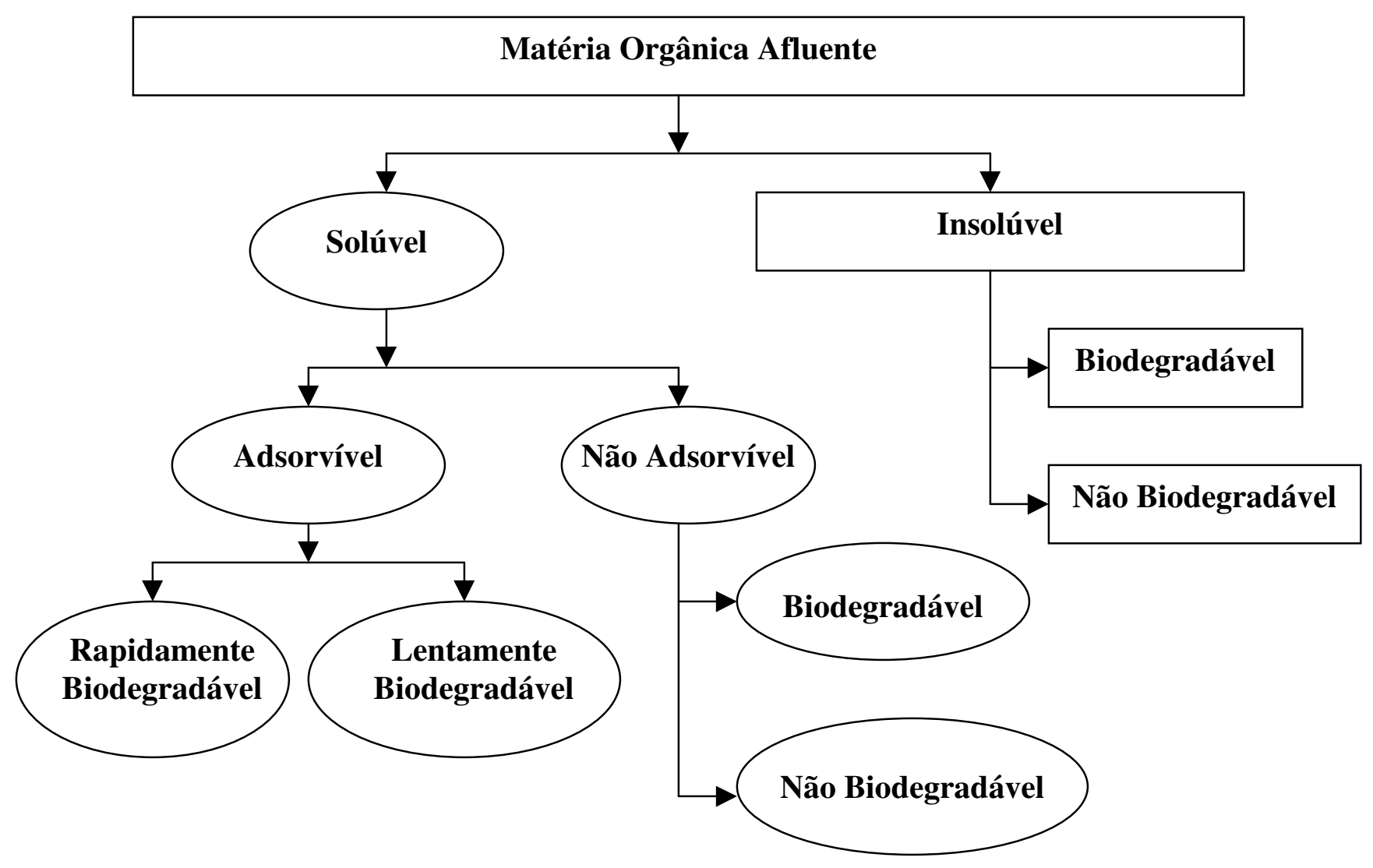

Figura 11 - Distribuição da Matéria Orgânica Afluente - Adaptado de Ros, Milenko $-1993$. 
Como já citado, toda descrição dada no começo deste item, se refere ao fracionamento adotado pelo modelo matemático desenvolvido pela UCT, que foi o adotado neste trabalho. Torna-se evidente que cada autor ou linha de modelagem matemática faz o fracionamento da matéria orgânica do afluente de forma diferenciada, para ser usada no modelo matemático proposto por cada um deles. Logo, a escolha do modelo depende da forma escolhida para o fracionamento e viceversa.

\subsubsection{Metodologias de Determinação da Taxa de Consumo (Utilização) de Oxigênio}

A técnica de respirometria para obtenção da Taxa de Consumo de Oxigênio (TCO), é citada em todas as metodologias consultadas de determinação das frações orgânicas do substrato, principalmente para obter a fração rapidamente biodegradável.

Uma das necessidades de qualquer modelo matemático, que queira descrever o comportamento de um sistema aeróbio, lodos ativados neste caso, necessita dos valores dos coeficientes cinéticos, ou seja, necessita-se saber com que velocidade a biomassa processa o substrato a ser avaliado no modelo. Também se tornam necessárias estas informações, para um bom controle do processo, sendo que esta técnica foi e ainda é muito estudada para este fim (Spanjers, H. et al - 1998).

Entretanto, não é possível medir diretamente a velocidade com que o substrato proveniente de esgotos domésticos, está sendo consumido ou utilizado pela biomassa. Não de uma forma simples, devido à presença da matéria particulada. Assim sendo, usa-se uma forma indireta para determinar a velocidade e a quantidade de substrato consumida pela biomassa: a demanda de oxigênio.

A finalidade da medida da TCO é então, avaliar a velocidade do metabolismo da biomassa, já que o consumo de oxigênio está intimamente ligado à sua atividade, tanto em relação ao substrato presente no esgoto, como no seu decaimento, denominado, então, de respiração endógena. Esta última ocorre todo o tempo, 
simultaneamente com a digestão do substrato. Porém, obviamente só se consegue medi-la na ausência do substrato, situação na qual este não interfere. (Andreottola 2005)

O consumo de oxigênio, no entanto, pode ocorrer por outros meios que não pela biomassa; como por exemplo, a oxidação química do íon de ferro II a ferro III devido à presença de oxigênio. Outras espécies reduzidas também podem ser oxidadas, como íons reduzidos de enxofre (sulfeto, sulfito) ou outros (fosfito, hipofosfito etc.) que possam estar presentes no afluente ao sistema.

Bactérias autotróficas, como as nitrificantes, consomem o oxigênio dissolvido para oxidar o nitrogênio na forma amoniacal a nitrito, e depois de nitrito a nitrato.

Sulfobactérias também se utilizam do oxigênio dissolvido para oxidar íons sulfurados (sulfeto, sulfito) à sulfato. Ferrobactérias também usam oxigênio para oxidar o íon ferro II a ferro III, sendo que em todos estes processos oxidativos a finalidade é adquirir energia química para reprodução e síntese.

Entretanto não há consumo de substrato orgânico, a fonte de carbono para as bactérias autotróficas é o gás carbônico dissolvido, normalmente na forma de bicarbonato.

O que é necessário ter claro quando se faz uso da TCO, é que ela é uma medida geral, ou seja, o que se mede é simplesmente a diminuição da concentração de oxigênio dissolvido em função do tempo, independente da causa. Para obter um resultado útil desta medida, é necessário definir bem o uso que terá este resultado. A partir daí, o teste tem de ser realizado em circunstâncias que isolem as outras interferências.

Por exemplo, se a intenção é determinar somente a TCO resultante da metabolização de matéria orgânica, é necessário inibir a nitrificação, caso o sistema em estudo seja capaz de nitrificar. Em suma, o arranjo do teste de TCO é que direciona o resultado que se pretende obter.

Uma das limitações desta técnica é quanto às oxidações químicas, que dificilmente são possíveis de serem isoladas. Contudo, para esgotos tipicamente 
domésticos, a presença destas espécies pode ser negligenciada na maior parte dos casos. No caso do efluente de UASB existe a presença de sulfetos, todavia, devido à forma que foi efetuada a coleta, muita agitação com ar, adotou-se também como desprezível a interferência desta espécie química.

No caso da respiração devido ao uso do substrato orgânico, tem-se uma representação na figura 12 apresenta a distribuição intercelular no consumo do substrato no processo respiratório. Novamente é necessário citar que dentro deste âmbito de estudos bioquímicos, o que é apresentado neste trabalho é um breve resumo, simplesmente para deixar um pouco mais claro o tópico em questão. Há um vasto número de estudos, sobre os mecanismos internos da célula no processo respiratório, os quais não é a pretensão deste trabalho elucidar.

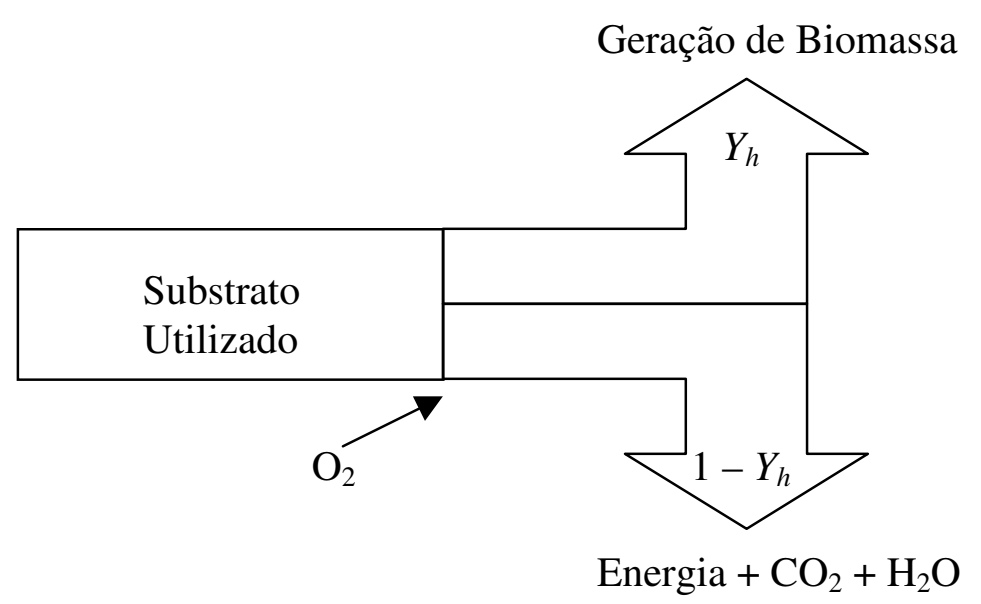

Figura 12 - Representação esquemática da respiração pela biomassa heterotrófica. (adaptado de IAWQ - 1998).

Como já citado anteriormente no item 3.5.2 Sistema de Lodos Ativados, a biomassa sofre decaimento, ou seja, há a morte dos microrganismos. Com este fato, introduz-se uma nova quantidade de substrato orgânico, um resíduo muito lentamente biodegradável, chamado de resíduo endógeno.

A parte biodegradável deste material orgânico realimenta a própria biomassa. Sendo assim, há novamente um crescimento independente do substrato do afluente, mas menor que o decaimento, devido à formação do resíduo endógeno. 
Este enfoque dá origem a um modelo conhecido como "morte regeneração". No modelo tido como tradicional esta parcela de realimentação do sistema não existe. A figura 13 traz um esquema destes dois modelos, de forma a melhor visualizá-los.

A principal conclusão que deve ser tirada do exposto até agora é que quanto maior for a fração ativa do lodo, maior será a respiração endógena. Como a atividade da biomassa está diretamente ligada à idade do lodo, tem-se que para um lodo “jovem” (4 dias p. ex.) resulta uma maior TCO endógena e o inverso para um lodo "velho".

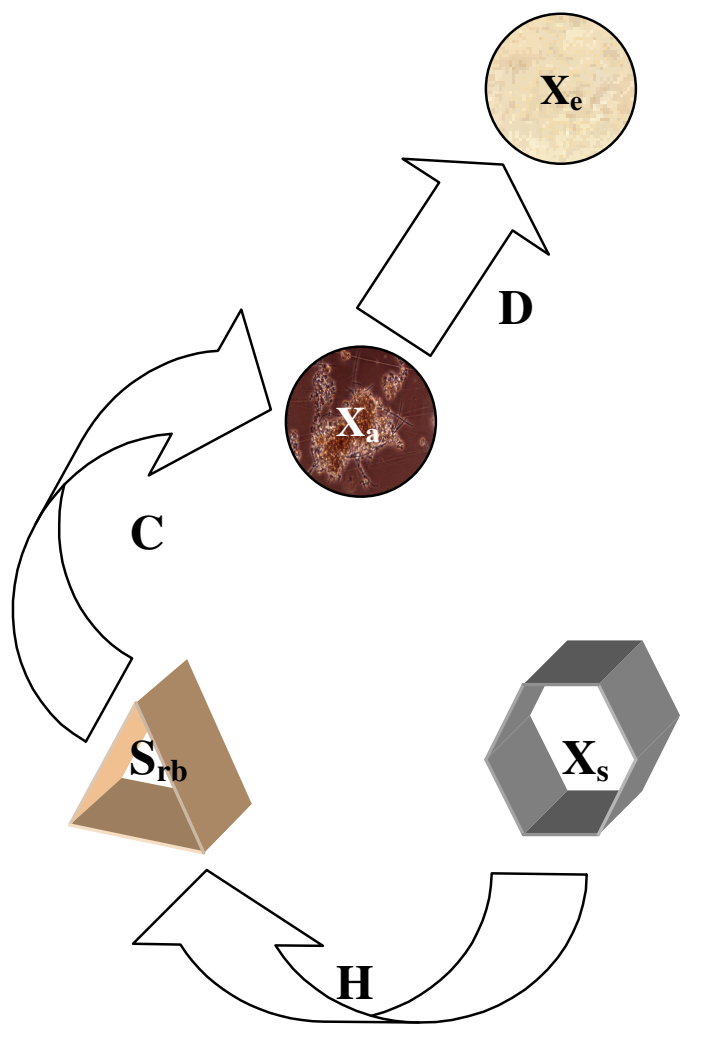

(a)

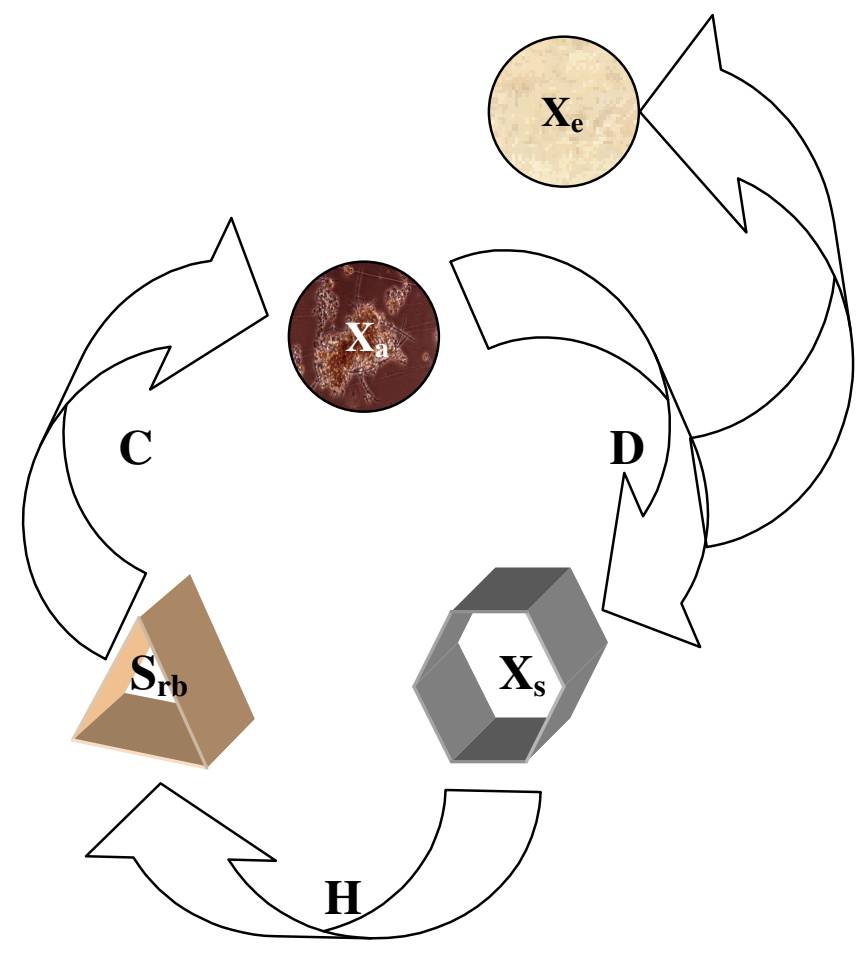

(b)

$\mathrm{H}=$ Hidrólise $; \mathrm{C}=$ Crescimento $; \mathrm{D}=$ Decaimento; $\mathrm{X}_{\mathrm{s}}=$ Substrato Lentamente biodegradável; $S_{\mathrm{rb}}=$ Substrato rapidamente biodegradável; $X_{\mathrm{a}}=$ biomassa; $X_{\mathrm{e}}=$ Matéria inerte (Resíduo endógeno)

Figura 13 - modelo tradicional (a) e modelo "morte - regeneração"(b) (Adaptado de IAWQ - 1998) 
No que tange ao substrato, a sua respectiva TCO dependerá de alguns fatores, como, por exemplo, a fração rapidamente biodegradável. Quanto maior ela for, maior será a TCO, pois o processo metabólico é imediato. Se esta fração for pequena, o metabolismo celular dependerá de outro mecanismo externo, que será o fator limitante para a respiração: a hidrólise. Logo, o que regerá a TCO será outra taxa, a de hidrólise ou ainda a de desorção.

A TCO também dependerá da concentração do substrato e da biomassa, pois quanto maior a concentração de microrganismos, maior será a quantidade de oxigênio consumido por unidade de tempo. Não obstante, quanto mais concentrado for o substrato, maior a disponibilidade para os microrganismos, facilitando a metabolização. Todavia, neste caso existirá um limite, o próprio $\mu_{\text {máx. }}$ da biomassa em relação a este substrato.

Segundo Spanjers et al (1998), há duas classificações básicas nos métodos e, por conseqüência, nos equipamentos para realizar a medida da TCO.

A primeira se refere à fase em que a medida do oxigênio é realizada: na fase gasosa ou na líquida. A segunda se refere ao comportamento das duas fases durante o processo de medida, ou seja, se são estáticos ou dinâmicos (figura 14).
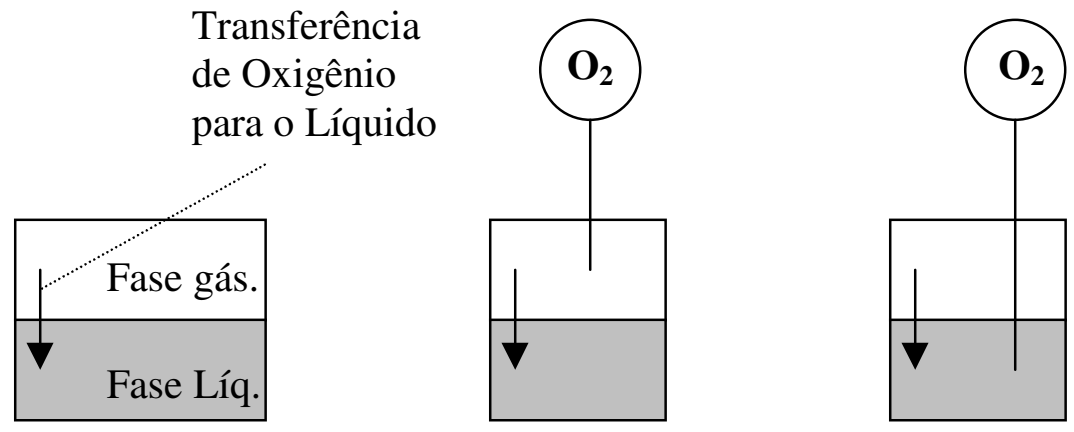

Figura 14 - Ilustração das formas de medida do oxigênio consumido. (Adaptado IAWQ - 1998) 
Quando a medida do oxigênio é realizada na fase gasosa, o princípio de medida pode ser através de uma sonda de oxigênio, por deslocamento de volume ou mudança de pressão. Para os dois últimos, só se a fase gasosa for estática durante a medida.

No caso da medida ser realizada no meio líquido, o princípio é através de uma sonda de oxigênio, para ambas as situações: estática ou dinâmica.

Existem vários modelos de respirômetros, os quais operam nas diversas formas combinadas, medidas no gás e com fase gasosa dinâmica e líquida estática, fase gasosa estática e líquida dinâmica, ambas dinâmicas ou estáticas, etc.

O sistema mais simples para executar a medida da TCO, em termos de número de variáveis, é com ambas as fases estáticas e a medida de oxigênio na fase líquida. Em essência, aera-se até um determinado valor de OD e acompanha-se o seu decaimento (teste em batelada ou semi - contínuo ).

A maior desvantagem deste procedimento é a necessidade de reaeração, uma vez que o OD está sendo consumido e após um período (que depende da TCO) atinge uma parte não linear do decaimento, abaixo de $\sim 1 \mathrm{mgO}_{2} / \mathrm{L}$, devido à restrição de concentração do oxigênio no líquido.

Por outro lado, quando se usa desta configuração com um equipamento automático, que controla a reaeração e a medida de decaimento do OD automaticamente, sua operação se torna bastante simples (figura 15). Além disso, na maioria das outras configurações é necessário ainda conhecer a $\mathrm{K}_{\mathrm{L}} \mathrm{a}$, que é a constante de transferência de oxigênio do reator, e neste caso também o valor do OD de saturação no líquido, enquanto que na configuração em batelada, precisa-se determinar unicamente a queda do OD e o tempo decorrido. 


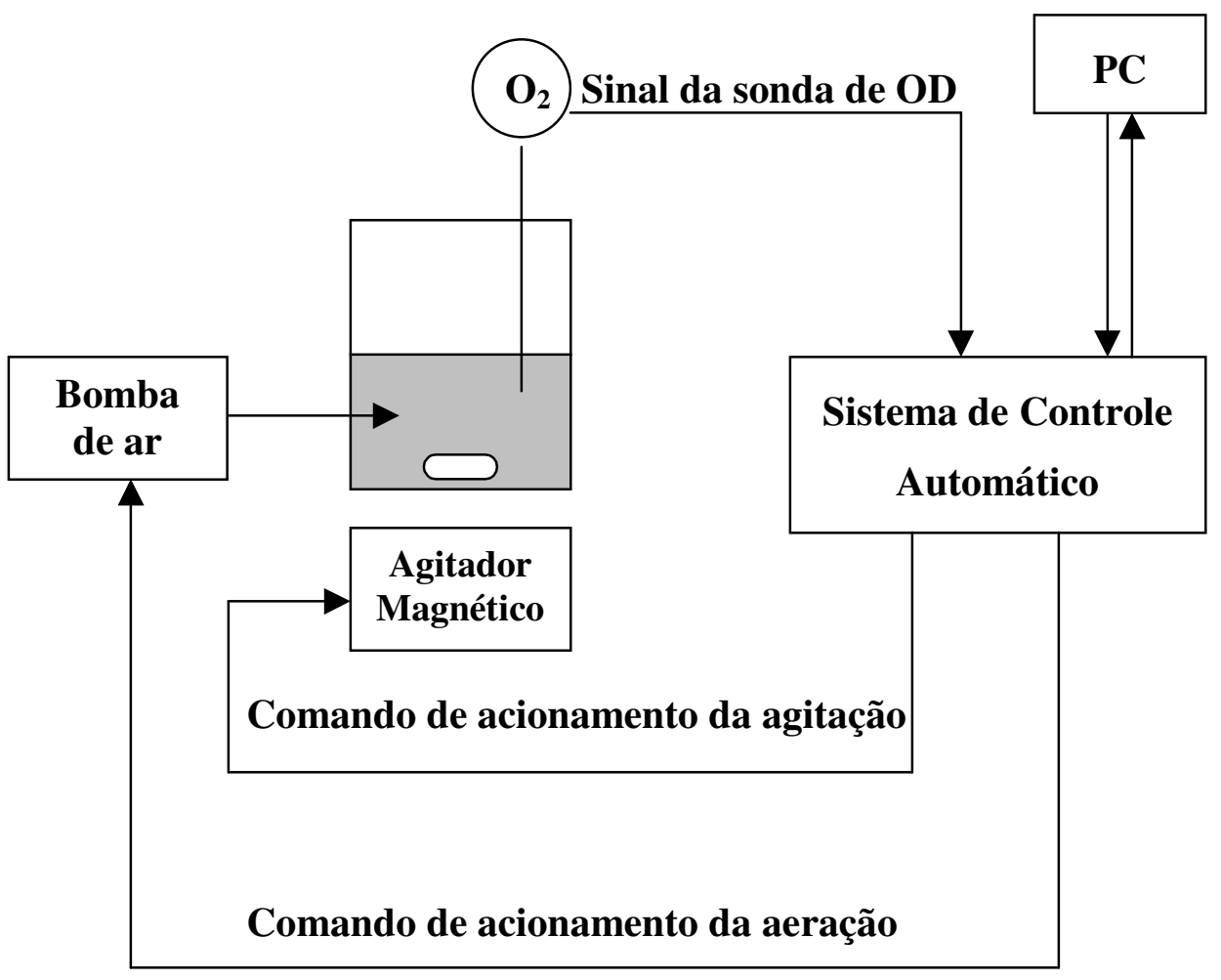

Figura 15 - Esquema básico de um respirômetro de medida em batelada com controle automático e interfaceado a um microcomputador. (adaptado de IAWQ 1998) 


\section{MATERIAL E MÉTODOS}

\subsection{Características do reator UASB}

O efluente de reator UASB usado para este trabalho foi o do reator instalado no Centro Tecnológico de Hidráulica, localizado na cidade universitária da USP (Foto 6), em São Paulo, que recebe esgoto do CRUSP - Conjunto Residencial da USP. Este reator é do tipo cilíndrico, cujas dimensões podem ser observadas na Figura 16.

Este sistema também possui um pré - tratamento que consiste de uma grade fina, caixa de areia e uma caixa de sucção que opera como uma caixa de gordura. Seu efluente já é utilizado para vários experimentos e projetos pilotos do Departamento de Engenharia Hidráulica e Sanitária Escola Politécnica da USP. A vazão de projeto é de $3 \mathrm{~m}^{3} / \mathrm{h}$, com tempo de detenção de $8 \mathrm{~h}$, o volume útil total é de $24,5 \mathrm{~m}^{3}$. Existem também 8 tubulações de amostragem a cada $0,5 \mathrm{~m}$ começando do piso do reator. Estas tubulações não estão apresentadas na Figura - 16. 


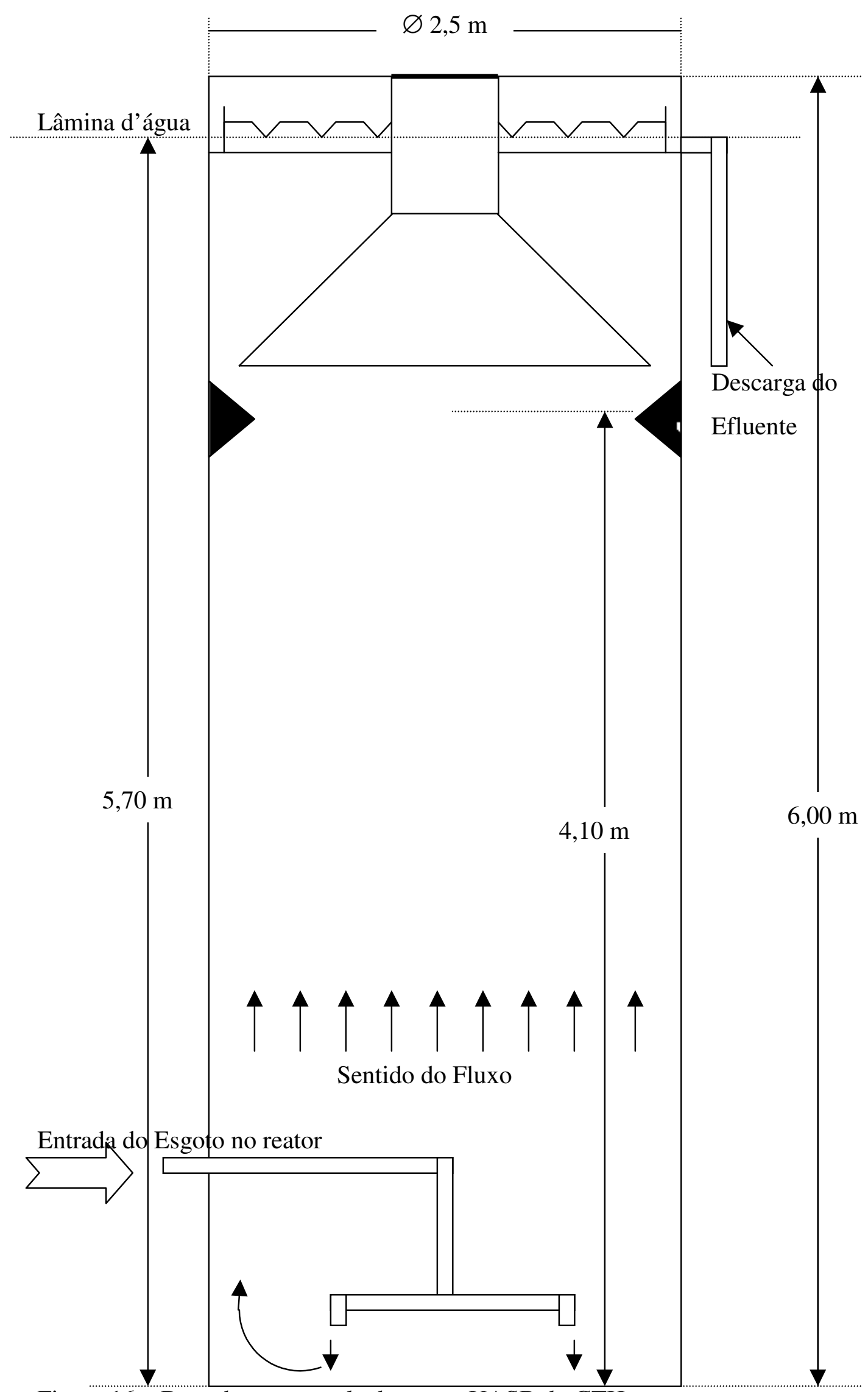

Figura 16 - Desenho sem escala do reator UASB do CTH 


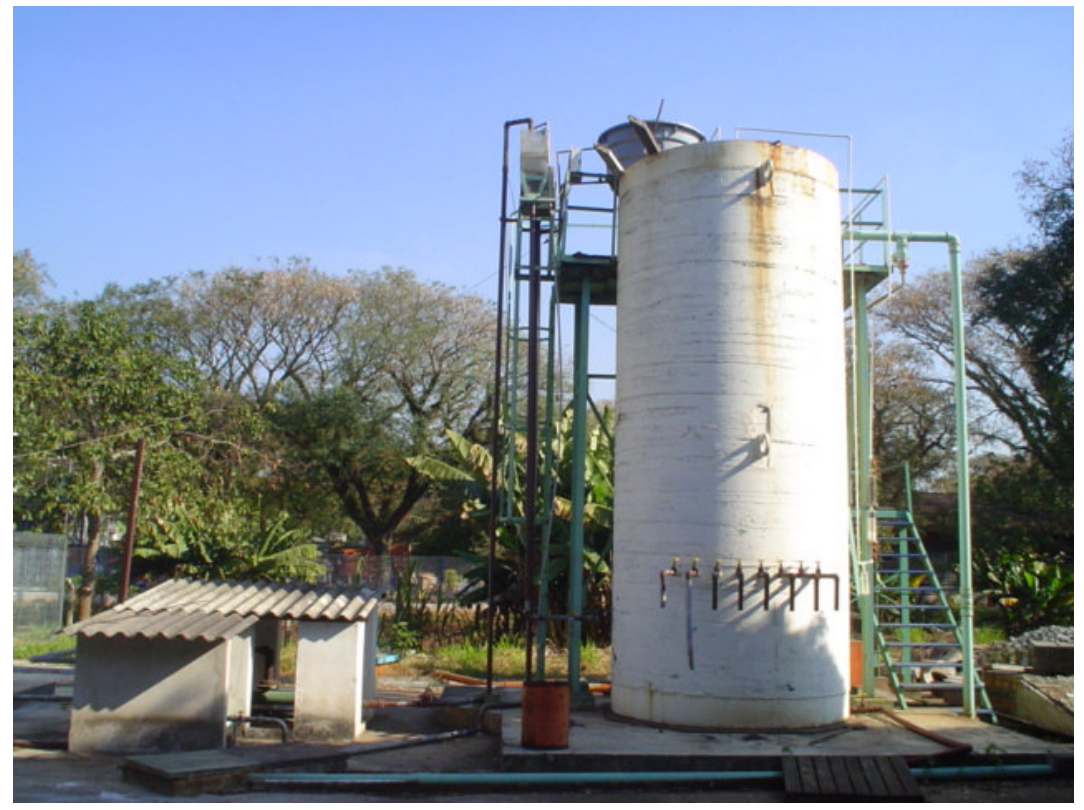

Foto 6 - Reator UASB do CTH

O efluente do reator foi coletado uma vez por semana, com um volume suficiente para manter pelo mesmo período o reator piloto funcionando ( 65 L/semana), sendo preservado em câmara frigorífica.

\subsection{Métodos Analíticos usados na determinação dos parâmetros físico - químicos}

As determinações analíticas seguiram os métodos analíticos recomendados pelo Standard Methods of Water and Wastewater, 20 ed (Washington, APHA/AWWA/WEF, 1995). Os parâmetros avaliados no afluente e efluente do reator bem como os métodos utilizados são apresentados na Tabela 3.

No conteúdo do reator foram determinados apenas as concentrações de SST, SSV e SSed. Isto porque em teoria, sendo o reator de mistura completa, as concentrações de espécies dissolvidas no interior do reator são iguais aos do efluente do reator. Neste caso, só há alteração em relação às partículas sólidas, que são previamente separadas no decantador. 
Tabela 3 - Parâmetros analisados no afluente e efluente do reator piloto com seus respectivos métodos.

\begin{tabular}{|c|c|}
\hline Parâmetros & Métodos \\
\hline SST - sólidos em suspensão totais & Gravimétrico \\
\hline SSV - sólidos em suspensão voláteis & Gravimétrico \\
\hline DQO total - demanda química de oxigênio total & Titulométrico, refluxo aberto \\
\hline DQO sol - demanda química de oxigênio solúvel & $\begin{array}{l}\text { Filtração em membrana de } \\
0,45 \mu \mathrm{m} \text {, Titulométrico, refluxo } \\
\text { aberto }\end{array}$ \\
\hline $\mathrm{DBO}_{5,20}$ total - demanda bioquímica de oxigênio & Diluição, oxímetro \\
\hline NTK - nitrogênio total kjeldall & $\begin{array}{l}\text { Digestão, destilação, } \\
\text { colorimétrico }\end{array}$ \\
\hline $\mathrm{N}-\mathrm{NH}_{3}$ - nitrogênio amoniacal & $\begin{array}{l}\text { Destilação tamponada, } \\
\text { colorimétrico }\end{array}$ \\
\hline $\mathrm{N}-\mathrm{NO}_{3}{ }^{-}$- nitrogênio nitrato & $\begin{array}{l}\text { Coluna de redução de Cádmio, } \\
\text { colorimétrico }\end{array}$ \\
\hline
\end{tabular}

\subsection{Métodos para determinação das frações de DQO do efluente de UASB}

Por necessidade do próprio modelo, também é necessário se determinar as frações orgânicas do lodo ativado usado no experimento.

As frações do lodo ativado expressas em DQO, são:

- Fração ativa

- Fração endógena

- Fração particulada não biodegradável (ou inerte) 


\subsection{1 - Determinação da fração de DQO solúvel não biodegradável:}

Após a entrada em regime, foram coletadas amostras do efluente do reator de

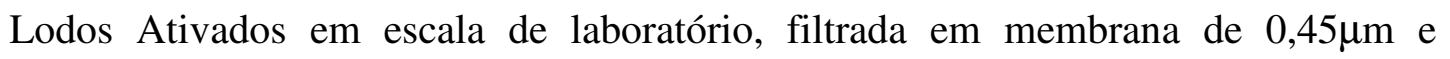
determinado o seu valor de DQO segundo metodologia já descrita. O valor obtido é considerado como sendo o valor de concentração da $\mathrm{DQO}_{\text {usa }}$. O valor para a fração é:

$$
f_{u s}=\mathrm{DQO}_{\mathrm{usa}} / \mathrm{DQO}_{\text {total }}
$$

\subsection{2 - Determinação da fração de DQO rapidamente biodegradável $\left(f_{\mathrm{rb}}\right)$ :}

Em princípio, de cada lote coletado do efluente do reator, seria realizado o teste de TCO em batelada com o lodo já condicionado do reator piloto. Entretanto, devido a vários problemas com o reator de lodos ativados, não foi possível realizar de todos os lotes. A metodologia para este ensaio está descrita mais adiante.

O acompanhamento da TCO em função do tempo no teste em batelada deveria apresentar características como as mostradas na Figura 17. Através da área formada pela demanda da $\mathrm{DQO}_{\mathrm{rb}}$, obtém-se a massa de DQO envolvida no catabolismo, que através da relação estipulada por Ekama, Dold \& Marais e van Haandel \& Marais, 1/3 para catabolismo e 2/3 para anabolismo, tem-se:

$$
\begin{aligned}
& \mathrm{m}=\mathrm{A} \\
& \mathrm{M}=3 . \mathrm{m} \quad \text { para } \mathrm{Y}_{\mathrm{h}}=0,45 \mathrm{mgSSV} / \mathrm{mgDQO} \text { removido } \\
& \mathrm{DQO}_{\mathrm{rb}}=\mathrm{M} / \mathrm{V}_{\text {EFL.UASB }} \\
& \mathrm{f}_{\mathrm{rb}}=\mathrm{DQO}_{\mathrm{rb}} / \mathrm{DQO}_{\text {total afluente }}
\end{aligned}
$$

Onde:

$\mathrm{A}=$ Área descrita pela curva da TCO

$\mathrm{m}=$ massa de oxigênio envolvida no catabolismo $\left(\mathrm{em} \mathrm{mg} \mathrm{\textrm {O } _ { 2 }}\right)$

$\mathrm{M}=$ massa total de matéria orgânica utilizada expressa em DQO (em mg $\mathrm{O}_{2}$ )

$\mathrm{V}_{\mathrm{EFL} \text { UASB }}=$ volume de efluente de UASB usado no teste. 
$\mathrm{DQO}_{\mathrm{rb}}=\mathrm{DQO}$ rapidamente biodegradável $(\mathrm{em} \mathrm{mg} \mathrm{O} / \mathrm{L})$

$\mathrm{f}_{\mathrm{rb}}=$ fração rapidamente biodegradável da DQO total afluente

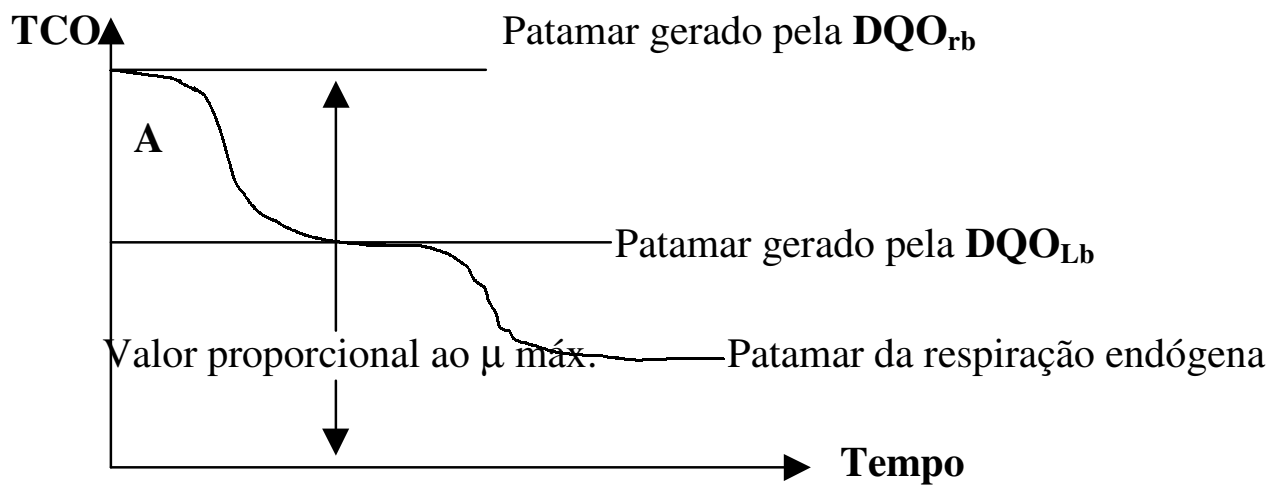

Figura 17 - Gráfico do comportamento da TCO em função do tempo.

OBS.: É possível determinar graficamente o valor para $\mu$ máx como demonstrado na figura, desde que não ocorra nitrificação no teste. (Ekama, Dold e Marais, 1986)

\subsection{3 - Determinação da fração de DQO particulada não biodegradável $\left(f_{\text {up }}\right)$ :}

A determinação da $f_{\text {up }}$ é realizada por balanço de massa no lodo ativado usado no experimento. Para isso é necessário determinar primeiro a fração ativa no lodo do reator.

Após todos os testes de TCO com o efluente do reator UASB, o lodo ativado do reator teve medido seu volume e concentração de sólidos e então colocado novamente no reator para digestão aeróbia. Antes de iniciada a digestão foi realizada uma determinação da TCO, a qual serve de referência do término da digestão. O período determinado para esta digestão é de no mínimo 20 dias e, além disso, a TCO deve ser no máximo $10 \%$ da inicial e, assim sendo, considera-se o lodo praticamente inerte. 
Ao término da digestão, foi medido o valor de SSV do lodo, determinando por diferença a massa ativa do lodo quando do início do processo. Porém, o cálculo requer uma correção, que é o de formação de resíduo endógeno durante a digestão.

$$
\begin{aligned}
& f_{a v}=\left(\mathrm{X}_{\mathrm{vi}}-\mathrm{X}_{\mathrm{v} \infty}\right) /\left[\mathrm{X}_{\mathrm{vi}}\left(1-f_{e}\right)\right] \\
& f_{a v}=\text { fração ativa do lodo } \\
& f_{e}=\text { fração endógena } \\
& \mathrm{X}_{\mathrm{vi}}=\text { massa de SSV inicial } \\
& \mathrm{X}_{\mathrm{v} \infty}=\text { massa final de SSV (após a digestão) }
\end{aligned}
$$

(Ekama, G. A., Dold, P. L. \& Marais, G. V. R. - 1986)

A fração endógena adotada, foi o valor de literatura: $f_{e}=0,2$. É argumentado pelos autores que este valor já foi largamente confirmado assim como os valores de $\mathrm{Y}$ e $b_{\mathrm{h}}$ que serão apresentados seguir.

\subsection{4 - Equações definidas no Modelo em Regime Permanente - (Marais e Ekama - 1976):}

$$
\begin{aligned}
& f_{u p}=X_{i a} \cdot f_{c v} / S_{t a} \Rightarrow X_{i a}=S_{t a} \cdot f_{u p} / f_{c v} \\
& M S_{b a}=Q \cdot\left(S_{t a}-S_{u s a}-X_{i a} \cdot f_{c v}\right) \\
& M X_{B, H}=M S_{b a} \cdot Y_{h} \cdot \theta_{c} /\left(1+b_{h} \cdot \theta_{c}\right) \\
& M X_{E}=f_{E} \cdot b_{h} \cdot \theta_{c} \cdot M X_{B, H} \\
& M X_{I}=f_{u p} \cdot \theta_{c} \cdot M S_{t i} / f_{c v} \\
& M X_{v}=M X_{B, H}+M X_{E}+M X_{I} \\
& M O_{c}=M S_{b a} \cdot\left(1-f_{c v} \cdot Y_{h}\right)+\left(1-f_{E}\right) \cdot b_{h} \cdot f_{c v} \cdot M X_{B, H} \\
& f_{a v}=M X_{B, H} / M X_{v}
\end{aligned}
$$

Onde: 
$M S_{b a}=\mathrm{DQO}_{\text {biodegradável }} /$ dia do afluente (em massa)

$M X_{B, H}=$ massa orgânica ativa no lodo ativado (expressa em SSV)

$M X_{E}=$ massa orgânica de resíduo endógeno no lodo (expressa em SSV)

$M X_{v}=$ massa orgânica total no lodo (expressa em SSV)

$M X_{I}=$ massa orgânica inerte no lodo (expressa em SSV)

$\theta_{c}=$ TRS ou IL (idade do lodo em dias)

$M O_{c}=$ demanda de oxigênio pela respiração

$f_{c v}=$ coeficiente de correlação entre DQO/SSV

$Y_{h}=$ coeficiente (taxa) de crescimento ( em mg SSV/mg DQO)

$b_{h}=$ coeficiente (taxa) de decaimento $\left(\mathrm{em} \mathrm{d}^{-1}\right)$

$S_{t a}=$ Matéria Orgânica total afluente em DQO

- Determinação de $M X_{B, H}$ :

$f_{a v}=M X_{B, H} / M X_{v}$

- Determinação de $M X_{E}$ :

$M X_{E}=f_{E} \cdot b_{h} \cdot \theta_{c} \cdot M X_{B, H}$

- $\quad$ Determinação de $M X_{I}$ :

$M X_{v}=M X_{B, H}+M X_{E}+M X_{I}$

- Determinação final da $f_{u p}$ :

$M X_{I}=f_{u p} \cdot \theta_{c} \cdot M S_{t i} / f_{c v}$ 
$f_{u p}=M X_{I} \cdot f_{c v} / \theta_{c} \cdot M S_{t i}$

- Determinação da fração da $\mathrm{DQO}_{\mathrm{b}}$

A $f_{b}$ é determinada por diferença:

$f_{b}=1-f_{u s}-f_{u p}$

\subsection{Método para determinação da taxa de consumo de oxigênio - TCO}

A medida da taxa de consumo de oxigênio (ou respirometria) é em princípio uma medida de fácil execução e resulta num valor absoluto, que é a quantidade de oxigênio dissolvido (em massa) que foi consumido num processo por uma dada unidade de tempo, independente da origem deste processo: químico, físico ou biológico (Spanjers, H. et al -1998).

Neste trabalho o procedimento usado foi do tipo batelada, com a medida da demanda de OD no próprio líquido. Como já exposto, no item 3.5.3, a medida é realizada aerando a amostra até um determinado valor de OD ou de tempo e após cessada a aeração medindo o decaimento do OD com o uso de um oxímetro. Concluindo, a medida se constitui da diferença entre as leituras de OD, antes e depois de valores preestabelecidos (tempo ou $\Delta \mathrm{OD}$ ), dividido pelo tempo decorrido entre as duas leituras.

Já existem inúmeros equipamentos automatizados/computadorizados para este propósito, como é o caso do Resp32C, respirômetro desenvolvido por van Haandel e sua equipe na Universidade Federal da Paraíba - UFPB, em Campina Grande. Este foi o equipamento usado nesta fase do trabalho.

Estes aparelhos são capazes de realizar medidas seqüenciais, da mesma amostra ou não, aerando e agitando automaticamente nos ciclos de cada determinação da TCO, e é claro, de registrar os valores obtidos. No caso em específico, o Resp32C registra a temperatura, os valores de OD e os valores 
calculados da TCO em função do tempo. Os valores de variação de OD limites (OD inicial e final em cada ciclo) são pré - determinados pelo operador.

A massa total de oxigênio consumida durante o teste pode ser determinada, integrando-se a área da curva formada pelas várias medidas da TCO, obtém-se a massa de oxigênio consumido neste período de tempo. Este é o princípio básico do teste realizado. Seguindo a metodologia proposta por Ekama, G. A., Dold, P. L. \& Marais, G. V. R. - 1986, temos os seguintes passos:

- Preparação da amostra: Determina-se o valor de SSV do lodo ativado e a DQO do efluente de UASB para o teste.

- Misturam-se volumes conhecidos do efluente do UASB com lodo ativado do reator piloto já adaptado, de forma a manter uma relação A/M numa faixa de 1 a 1,5 da $f_{a v}$. A $f_{a v}$ pode ser estimada pela seguinte equação: $f_{a v}=$ $1,41\left(\theta_{\mathrm{x}}\right)^{-0,53}$. Esta equação fornece apenas uma aproximação da fração ativa, e não deve ser utilizada nos cálculos finais, e sim apenas para a determinação da relação A/M.

- Inicia-se as medidas de TCO controlando-se a temperatura através de um banho-maria ou de gelo, em torno de $20^{\circ} \mathrm{C}$, valor no qual é determinado a maior parte das constantes cinéticas e estequiométricas. É importante o controle da temperatura durante o teste, principalmente se existe a intenção de se determinar o $\mu$ máx (como citado na observação da Figura 17). Porém, neste trabalho não teve no seu objetivo determinar este parâmetro.

Devido a resposta não satisfatória na respirometria, foi adotado um procedimento de aumento de quatro vezes da concentração do lodo ativado do reator para o ensaio. O procedimento para este aumento de concentração foi o seguinte:

- Mediu-se 400mL do lodo ativado em uma proveta;

- Deixou-se sedimentar por no mínimo 30 min., até o sobrenadante se tornar límpido e o volume de lodo fosse inferior a $100 \mathrm{~mL}$; 
- Através de um sifão retirou-se o sobrenadante sem agitar o lodo sedimentado no fundo, até restar $100 \mathrm{~mL}$;

- Homogeneizava-se o lodo e transferia-se para o frasco do respirômetro.

\subsection{Sistema Piloto de Lodos Ativados escala de Laboratório}

A primeira razão para a montagem desta unidade está implícita no item anterior: a necessidade de se ter um lodo ativado adaptado ao efluente. Logo, este reator foi a fonte de lodo adaptado para os testes de respirometria.

A segunda razão é a determinação da fração não biodegradável solúvel, obtida através do efluente tratado pelo sistema piloto.

A terceira razão está na obtenção da fração da DQO não biodegradável particulada. Esta, como demonstrado anteriormente na revisão bibliográfica, é determinada através de cálculos que levam em consideração a fração ativa do lodo.

Assim sendo, o reator foi projetado conforme duas limitações:

1) O transporte de efluente de UASB até o laboratório da Estação de Tratamento de Esgotos (ETE) - Barueri, onde foram montadas as unidades de testes.

2) A relação $\mathrm{A} / \mathrm{M}$ indicada pelo procedimento sugerido por Ekama, Dold \& Marais $-1986, \Rightarrow \mathrm{A} / \mathrm{M}<0,4$ (esta é a relação estabelecida para o teste em batelada.)

A limitação de transporte de efluente de UASB ficou estabelecida em 70L. A média da DQO efluente do reator UASB do CTH em anos anteriores foi de 188 $\mathrm{mgO}_{2} / \mathrm{L}$ (vide anexo B). Como medida de segurança foi adotado $150 \mathrm{mg}$ DQO/L. Isto porque o reator de pesquisa trabalhou com uma carga de DQO constante. Ou seja, quando a concentração de DQO esteve acima de $150 \mathrm{mg} / \mathrm{L}$, a vazão foi alterada para atingir a carga. Como $150 \mathrm{mg} / \mathrm{L}$ foi um dos valores mais baixos encontrados no 
acompanhamento realizado em 2002, foi adotado como referência para a alimentação do sistema. No período do teste foram encontrados alguns valores abaixo (vide Tabela 5) necessitando um aumento de vazão para compensar a carga. Contudo, a variação não foi demasiadamente grande, não causando distúrbios consideráveis na vazão afluente ao sistema em escala de laboratório.

A vazão máxima, considerando a limitação de transporte, ficou em 10L/dia, que pela concentração de SSV estimada no reator de $2500 \mathrm{mg} \mathrm{SSV/L}$, para uma A/M de $0,3=>5 \mathrm{~L}$ de efluente de UASB / L de reator . dia. Aproveitando ao máximo, o reator teve um volume útil de $2 \mathrm{~L}$.

Além do reator, o piloto foi composto de um decantador e uma bomba peristáltica (figura 18 e foto 7), a qual foi responsável pela alimentação do reator e pela recirculação do lodo sedimentado no decantador. Em princípio operou-se com uma razão de $100 \%$ de recirculação ( vazão afluente = vazão de recirculação). Devido à efeitos de denitrificação, a recirculação foi posteriormente alterada para $200 \%$.

O efluente do reator UASB foi coletado uma vez por semana, e guardado em câmara frigorífica até o uso, sendo retirado da câmara só o volume suficiente para o dia.

A partida foi realizada usando uma amostra de lodo ativado do tanque de aeração da ETE Barueri, e o TRS do reator foi de 10 dias, conforme descrito pelos autores . (Ekama, G. A., Dold, P. L. \& Marais, G. V. R. - 1986). Foi realizado descarte hidráulico diário do lodo, desde que mantidas boas condições de efluente do piloto, ou seja, perda irrisória de sólidos e baixa DQO do efluente. O tempo aceito para estabilização e entrada em regime do sistema é de três vezes o TRS, portanto após trinta dias de operação, o lodo já foi considerado adaptado, podendo-se então começar os testes de respirometria. 


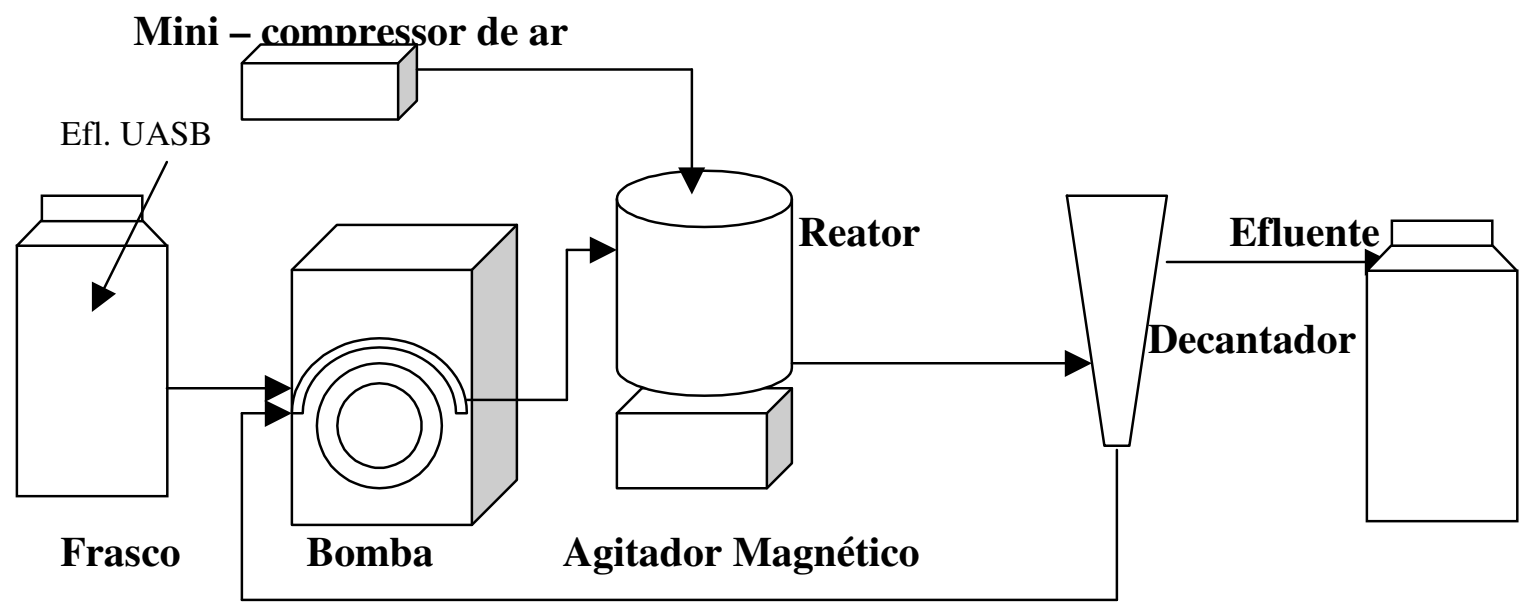

Figura 18 - Diagrama do sistema piloto em escala de laboratório

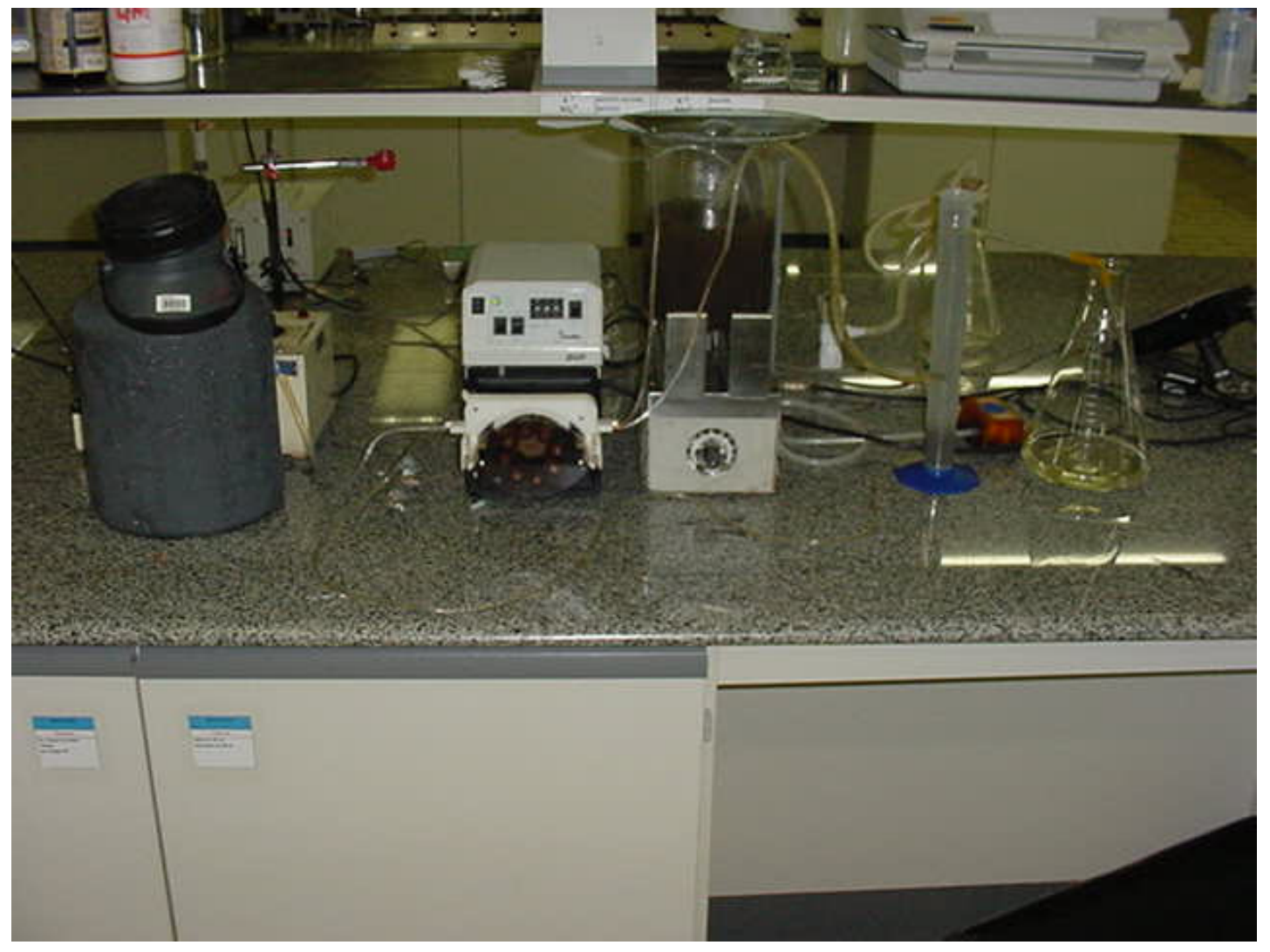

Foto 7 - Sistema de Lodos Ativados em escala de laboratório 


\section{RESULTADOS E DISCUSSÃO}

\subsection{Resultados gerais dos ensaios e sua discussão}

Devido a vários problemas operacionais e aos próprios resultados obtidos fezse necessário manter o sistema por muito mais que um mês, de fato, aproximadamente oito meses para se ter o sistema estabilizado.

Isto porque a cada perda de lodo por vazamento de mangueiras ou rompimento do reator, todo o processo tinha de ser novamente estabilizado, com espera de 3 vezes o TRS, ou seja, 30 dias. Só então era possível reiniciar os testes, sendo assim, não foi realizado a TCO de todos os lotes do efluente do UASB.

Conforme observado na Tabela 4 e no anexo $\mathrm{C}$, houve grande variação no valor de sólidos em suspensão totais (SST) e voláteis (SSV) do reator. A razão mais provável para este fenômeno deve ser a própria variação de SST/SSV do afluente e a conseqüente variação na $f_{p}$ da DQO afluente. Também houveram outras interrupções no trabalho devido a problemas no laboratório. Durante estes períodos, o conteúdo do reator foi mantido em câmara fria a $\mathrm{t}<4^{\circ} \mathrm{C}$.

Tabela 4 - Concentração de SST e SSV no reator piloto (2004 a 2005)- continua

\begin{tabular}{rrrrrrrc}
\hline DATA & SST & SSV & SSV/SST & DATA & SST & SSV & SSV/SST \\
\hline 29/jul & 2190 & 1780 & 0,81 & 24/ago & 1580 & 1290 & 0,82 \\
\hline 30/jul & 2400 & 1860 & 0,78 & 25/ago & 1300 & 1130 & 0,87 \\
\hline 02/ago & 2590 & 2120 & 0,82 & 26/ago & 1200 & 1040 & 0,87 \\
\hline 03/ago & 2370 & 1910 & 0,81 & 27/ago & 1340 & 1090 & 0,81 \\
\hline 04/ago & 2250 & 1880 & 0,84 & 29/ago & 1570 & 1280 & 0,82 \\
\hline 05/ago & 2000 & 1650 & 0,83 & 30/ago & 1790 & 1510 & 0,84 \\
\hline 06/ago & 1880 & 1560 & 0,83 & 31/ago & 1580 & 1310 & 0,83 \\
\hline 09/ago & 2320 & 1880 & 0,81 & 01/set & 1590 & 1280 & 0,81 \\
\hline 10/ago & 2010 & 1620 & 0,81 & 02/set & 1730 & 1450 & 0,84 \\
\hline 11/ago & 1560 & 1270 & 0,81 & 03/set & 1650 & 1400 & 0,85 \\
\hline 12/ago & 1530 & 1270 & 0,83 & 06/set & 1840 & 1520 & 0,83 \\
\hline 13/ago & 1660 & 1350 & 0,81 & 08/set & 1670 & 1380 & 0,83 \\
\hline 16/ago & 2060 & 1690 & 0,82 & 09/set & 1660 & 1350 & 0,81 \\
\hline 17/ago & 1620 & 1310 & 0,81 & 10/set & 1490 & 1270 & 0,85 \\
\hline 18/ago & 1390 & 1120 & 0,81 & 12/set & 1430 & 1120 & 0,78 \\
\hline 19/ago & 1270 & 1030 & 0,81 & 13/set & 1090 & 920 & 0,84 \\
\hline 20/ago & 1470 & 1180 & 0,80 & 14/set & 1310 & 1090 & 0,83 \\
\hline
\end{tabular}


Tabela 4 - Concentração de SST e SSV no reator piloto - Conclusão

\begin{tabular}{|c|c|c|c|c|c|c|c|}
\hline DATA & SST & SSV & SSV/SST & DATA & SST & SSV & SSV/SST \\
\hline $18 /$ set & 1370 & 1130 & 0,82 & 29/out & 1190 & 990 & 0,83 \\
\hline $20 /$ set & 1140 & 960 & 0,84 & $02 /$ nov & 1040 & 940 & 0,90 \\
\hline $21 /$ set & 1640 & 1370 & 0,84 & 03/nov & 1170 & 960 & 0,82 \\
\hline $22 /$ set & 1680 & 1450 & 0,86 & 04/nov & 1400 & 1110 & 0,79 \\
\hline $23 /$ set & 1620 & 1430 & 0,88 & 05/nov & 1310 & 1060 & 0,81 \\
\hline $24 /$ set & 1550 & 1320 & 0,85 & 08/nov & 1820 & 1460 & 0,80 \\
\hline $27 /$ set & 1720 & 1470 & 0,85 & 09/nov & 1570 & 1300 & 0,83 \\
\hline $28 /$ set & 1690 & 1500 & 0,89 & 10/nov & 1620 & 1320 & 0,81 \\
\hline $29 /$ set & 1640 & 1410 & 0,86 & 12/nov & 1125 & --- & --- \\
\hline $30 /$ set & 2090 & 1710 & 0,82 & 16/nov & 3600 & 2780 & 0,77 \\
\hline 01/out & 1520 & 1240 & 0,82 & 17/nov & 2440 & 1860 & 0,76 \\
\hline 04/out & 3050 & 2480 & 0,81 & 18/nov & 2510 & 1970 & 0,78 \\
\hline 05/out & 2560 & 2110 & 0,82 & $22 /$ nov & 2190 & 1740 & 0,79 \\
\hline 06/out & 2820 & 2300 & 0,82 & 23/nov & 1680 & 1270 & 0,76 \\
\hline 07/out & 2440 & 1950 & 0,80 & $24 /$ nov & 1810 & 1380 & 0,76 \\
\hline 08/out & 2370 & 1970 & 0,83 & 25/nov & 1890 & 1460 & 0,77 \\
\hline 11/out & 2140 & 1750 & 0,82 & 26/nov & 1870 & 1420 & 0,76 \\
\hline 13/out & 3090 & 2480 & 0,80 & 28/nov & 1990 & 1520 & 0,76 \\
\hline $15 /$ out & 2470 & 2010 & 0,81 & 29/nov & 2630 & 2000 & 0,76 \\
\hline 17/out & 2210 & 1790 & 0,81 & 30/nov & 2300 & 1790 & 0,78 \\
\hline 18/out & 2090 & 1670 & 0,80 & $03 / \mathrm{dez}$ & 3150 & 2450 & 0,78 \\
\hline 19/out & 2150 & 1680 & 0,78 & 10/dez & 2930 & 2280 & 0,78 \\
\hline 20/out & 1991 & 1564 & 0,79 & $12 / \mathrm{dez}$ & 2170 & 1750 & 0,81 \\
\hline 21/out & 1950 & 1500 & 0,77 & 17/dez & 2200 & 1800 & 0,82 \\
\hline 22/out & 1880 & 1490 & 0,79 & 20/dez & 2380 & 1890 & 0,79 \\
\hline 25/out & 1300 & 1080 & 0,83 & 24/jan & 2350 & 1800 & 0,77 \\
\hline 26/out & 1640 & 1360 & 0,83 & 25/jan & 1911 & 1502 & 0,79 \\
\hline 27/out & 1300 & 1080 & 0,83 & 26/jan & 1900 & 1440 & 0,76 \\
\hline 28/out & 1370 & 1080 & 0,79 & 28/jan & 2020 & 1620 & 0,80 \\
\hline Média = & 1850 & 1498 & $\mathbf{0 , 8 2}$ & & & & \\
\hline Máximo = & 3600 & 2780 & 0,90 & & & & \\
\hline Mínimo = & 1040 & 720 & 0,76 & & & & \\
\hline DP-médio = & 412 & 309 & $\mathbf{0 , 0 2 3}$ & & & & \\
\hline DP-Normal = & 515 & 391 & $\mathbf{0 , 0 3 0}$ & & & & \\
\hline DP-Normal = & $28 \%$ & $26 \%$ & $3,7 \%$ & & & & \\
\hline
\end{tabular}

A variação das características do efluente do reator UASB pode ser vista na Tabela 5. 
Tabela 5 - monitoramento do efluente do reator UASB (Afluente ao sistema Piloto)

\begin{tabular}{|c|c|c|c|c|c|c|c|}
\hline DATA & $\begin{array}{l}\mathrm{DQO} \\
\text { total } \\
\end{array}$ & $\begin{array}{l}\text { DQO } \\
\text { solúivel }\end{array}$ & $\begin{array}{l}\text { DQO } \\
\text { particul. }\end{array}$ & SST & SSV & $\begin{array}{l}\text { DQOp } \\
\text { /SST }\end{array}$ & $\begin{array}{l}\text { DQOp } \\
\text { /SSV }\end{array}$ \\
\hline 20/abr & 168 & 66 & 102 & 62 & 52 & 1,65 & 1,96 \\
\hline $27 / a b r$ & 112 & 71 & 41 & 48 & 44 & 0,85 & 0,93 \\
\hline 4/mai & 158 & 59 & 99 & 45 & 37 & 2,22 & 2,65 \\
\hline 11/mai & 152 & 53 & 99 & 38 & 35 & 2,62 & 2,83 \\
\hline 19/mai & 292 & 58 & 234 & 150 & 118 & 1,56 & 1,98 \\
\hline 25/mai & 213 & 72 & 141 & 80 & 66 & 1,76 & 2,14 \\
\hline 8/jun & 152 & 62 & 90 & 42 & 37 & 2,16 & 2,43 \\
\hline 22/jun & 168 & 76 & 92 & 40 & 36 & 2,30 & 2,56 \\
\hline 10/ago & 204 & 73 & 131 & 85 & 72 & 1,54 & 1,82 \\
\hline 17/ago & 176 & 66 & 110 & 65 & 53 & 1,69 & 2,08 \\
\hline 24/ago & 217 & 35 & 182 & 69 & 61 & 2,64 & 2,98 \\
\hline 3/set & 202 & 78 & 124 & 39 & 36 & 3,21 & 3,47 \\
\hline $14 /$ set & 197 & 82 & 115 & 50 & 44 & 2,30 & 2,61 \\
\hline $20 /$ set & 161 & 63 & 98 & 96 & 81 & 1,02 & 1,21 \\
\hline $29 /$ set & 312 & 104 & 208 & 163 & 127 & 1,28 & 1,64 \\
\hline 14/out & 177 & 90 & 87 & 164 & 134 & 0,53 & 0,65 \\
\hline 19/out & 106 & 56 & 50 & 29 & 25 & 1,74 & 1,98 \\
\hline 25/out & 134 & 84 & 50 & 45 & 40 & 1,11 & 1,25 \\
\hline 4/nov & 320 & 76 & 244 & 166 & 134 & 1,47 & 1,82 \\
\hline $17 /$ nov & 143 & 69 & 74 & 55 & 49 & 1,35 & 1,51 \\
\hline $25 /$ nov & 171 & 63 & 108 & 66 & 55 & 1,64 & 1,96 \\
\hline 8/dez & 166 & 88 & 78 & 52 & 20 & 1,50 & 3,90 \\
\hline 18/jan & 161 & 80 & 81 & 41 & 35 & 1,98 & 2,31 \\
\hline Média = & 185 & 71 & 115 & 73 & 60 & 1,74 & 2,12 \\
\hline Máximo = & 320 & 104 & 244 & 166 & 134 & 3,21 & 3,90 \\
\hline Mínimo = & 106 & 35 & 41 & 29 & 25 & $\mathbf{0 , 5 3 0}$ & 0,65 \\
\hline DP - Médio= & 56 & 15 & 55 & 44 & 35 & 0,625 & 0,77 \\
\hline DP-Normal = & 46 & 11 & 44 & 38 & 29 & 0,532 & 0,56 \\
\hline DP-Normal = & $25 \%$ & $16 \%$ & $38 \%$ & $52 \%$ & $48 \%$ & $30 \%$ & $26 \%$ \\
\hline
\end{tabular}

Como é possível de se observar na Tabela 5, há uma grande variação do efluente ao longo do tempo no teor de sólidos, o que causa impacto direto na concentração de DQO, fazendo com que os valores das frações da DQO também oscilem. Constatou-se que a relação DQOp/SSV foi de 2,12, cerca de $41 \%$ maior que o determinado em muitos outros trabalhos $(\sim 1,5)$, largamente divulgados na literatura. 
Isto reforça o conceito de que algumas frações só terão sentido na forma de média, mais especificamente a fup .

- No que tange às taxas respirométricas (TCO's), os resultados na maior parte dos casos não foi satisfatória devido aos baixos valores de TCO. Para poder obter uma medida significativa, era necessário concentrar o lodo ativado do reator piloto em até quatro vezes.

Mesmo com este recurso, os gráficos na maioria das vezes apresentavam muita oscilação, o que prejudicava a interpretação do mesmo.

Na Figura 19 tem-se uma curva respirométrica sem concentrar o lodo ativado e na Figura 20 com o lodo ativado concentrado 4 vezes. Observou-se que o perfil da curva foi sempre ascendente, diferente do esperado (Figura 17) se houvesse matéria orgânica rapidamente biodegradável.

Estas curvas foram realizadas sem inibição de nitrificação, logo estas também não poderiam ser usadas para a determinação do $\mu_{\text {máx. }}$. Foi adotado a não inibição, na maioria das curvas, para evitar que houvesse alguma interferência do inibidor no processo metabólico da matéria orgânica, como citado por Ekama, G.A., Dold, P.A., Marais, G.V.R.(1986). Fazia-se necessário então, conhecer o comportamento da curva antes de tentar determinar o $\mu_{\text {máx. }}$.

Como o comportamento das curvas respirométricas apresentavam indicação da ausência de matéria orgânica rapidamente biodegradável, não foram realizados os testes com inibição. Isto porque o $\mu_{\text {máx }}$ só é possível determinar quando o crescimento celular é o fator limitante. Neste caso, a matéria orgânica ainda tem de ser hidrolizada, sendo este o fator limitante. 


\section{Respirômetro 3.2C}

- 目网

Arquivo Qppções Respirômetro Auunda

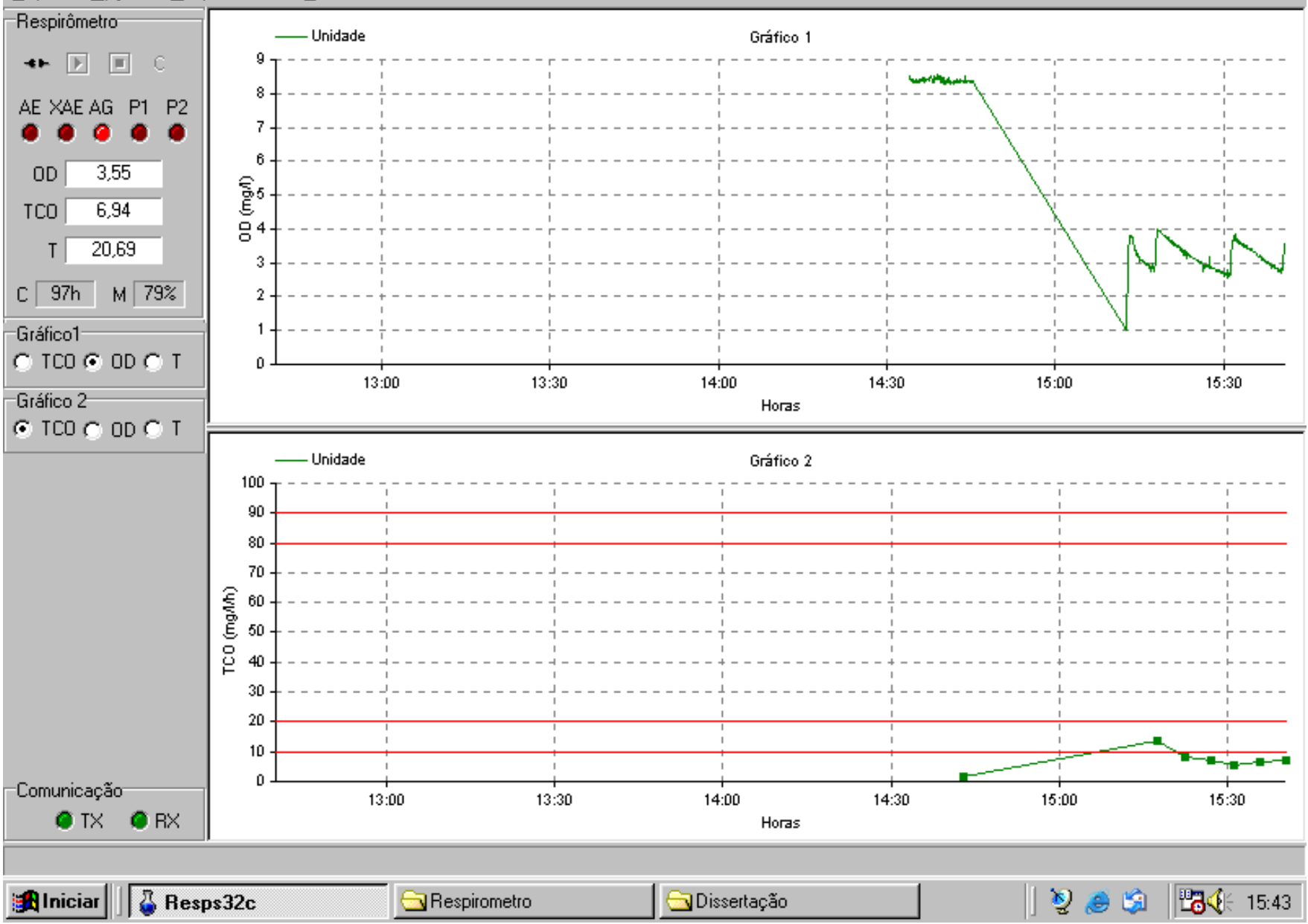

Figura 19 - Tela do programa do respirômetro Resp32C - Lodo ativado sem concentrar 


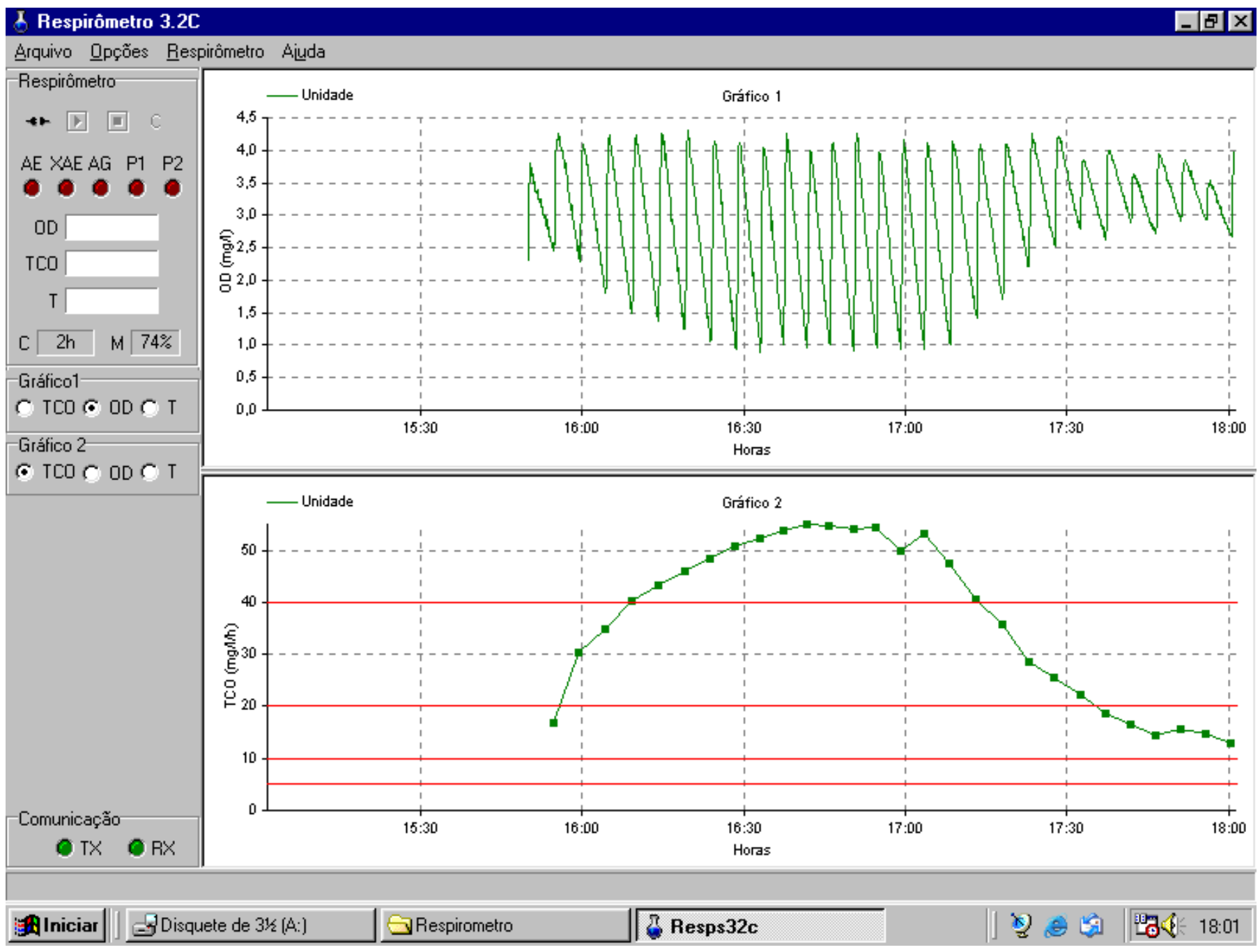

Figura 20 - Tela do programa do respirômetro Resp32C - lodo ativado concentrado 4 vezes.

O estudo por respirometria de biodegradabilidade de cargas orgânicas é mais rápido quando comparado a outros métodos, como por exemplo a DBO. Porém, o tempo para utilização da amostra tem a mesma restrição, ou seja, o teste tem de ser efetuado no máximo em até 48 horas da coleta da amostra, desde que preservada a $4^{\circ} \mathrm{C}$, tal como para DBO.

Neste ponto do trabalho, já se tinha determinado uma das frações da DQO que é a $f_{r b} \sim 0$. Isto implica numa dificuldade do uso de sistemas de remoção de nutrientes que dependem desta fração da matéria orgânica. 
$\mathrm{A} f_{u s}$, foi determinada pela DQO solúvel à saída do decantador do sistema de testes. Estes valores relativos ao efluente do sistema são apresentados na Tabela 6 .

Tabela 6 - Variação das características do efluente do sistema piloto

Efluente

(DQO particulada)

\begin{tabular}{|c|c|c|c|c|c|c|c|c|}
\hline PERÍODO & $\begin{array}{l}\mathrm{DQO} \\
\text { total }\end{array}$ & DQOs & $\overline{\mathrm{DQOp}}$ & SST & $\overline{S S V}$ & SSV/SST & $\begin{array}{l}\mathrm{DQO} \\
/ \mathrm{SST}\end{array}$ & $\begin{array}{l}\mathrm{DQO} \\
\text { /SSV }\end{array}$ \\
\hline $16 / 5-20 / 5$ & 61 & 35 & 26 & 16 & 12 & 0,76 & 1,55 & 2,03 \\
\hline $25 / 5-30 / 5$ & 52 & 35 & 17 & 10 & 10 & 0,93 & 1,57 & 1,70 \\
\hline $04 / 6-08 / 6$ & 54 & 32 & 22 & 6 & 5 & 0,91 & 3,79 & 4,15 \\
\hline $09 / 6-16 / 6$ & 66 & 36 & 30 & 7 & 5 & 0,77 & 4,55 & 5,88 \\
\hline $04 / 8-08 / 8$ & 64 & 49 & 15 & 11 & 9 & 0,81 & 1,39 & 1,70 \\
\hline $10 / 8-14 / 8$ & -- & -- & -- & 12 & 8 & 0,66 & -- & - \\
\hline $17 / 8-21 / 8$ & -- & -- & -- & 11 & 7 & 0,64 & -- & -- \\
\hline $22 / 8-26 / 8$ & -- & -- & -- & 5 & 4 & 0,91 & -- & -- \\
\hline $30 / 8-03 / 9$ & 51 & 38 & 13 & 11 & 10 & 0,93 & 1,20 & 1,30 \\
\hline $04 / 9-08 / 9$ & 53 & 38 & 15 & 10 & 9 & 0,84 & 1,44 & 1,72 \\
\hline $09 / 9-13 / 9$ & 55 & 38 & 17 & 9 & 8 & 0,86 & 1,93 & 2,24 \\
\hline $14 / 9-18 / 9$ & 49 & 37 & 12 & -- & -- & & -- & -- \\
\hline $20 / 9-24 / 9$ & 77 & 48 & 29 & 19 & 17 & 0,86 & 1,49 & 1,74 \\
\hline $03 / 10-06 / 10$ & 75 & 44 & 31 & 28 & 24 & 0,86 & 1,12 & 1,30 \\
\hline $08 / 10-12 / 10$ & 42 & 20 & 22 & 6 & 5 & 0,89 & 4,07 & 4,58 \\
\hline $15 / 10-19 / 10$ & 48 & 29 & 19 & 15 & 12 & 0,80 & 1,28 & 1,60 \\
\hline $20 / 10-24 / 10$ & 49 & 29 & 20 & 10 & 8 & 0,88 & 2,08 & 2,38 \\
\hline $25 / 10-30 / 10$ & 65 & 44 & 21 & 20 & 16 & 0,80 & 1,05 & 1,31 \\
\hline $03 / 11-07 / 11$ & 69 & 40 & 29 & 13 & 11 & 0,90 & 2,32 & 2,57 \\
\hline $10 / 11-14 / 11$ & 52 & 40 & 12 & -- & - & & -- & -- \\
\hline $13 / 11-17 / 11$ & 46 & 38 & 8 & 8 & 7 & 0,85 & 1,00 & 1,18 \\
\hline $18 / 11-22 / 11$ & 57 & 36 & 21 & 9 & 7 & 0,82 & 2,39 & 2,92 \\
\hline $23 / 11-28 / 11$ & 93 & 38 & 55 & 16 & 12 & 0,72 & 3,44 & 4,78 \\
\hline $29 / 11-03 / 11$ & 76 & 33 & 43 & 14 & 12 & 0,90 & 3,16 & 3,50 \\
\hline $09 / 12-13 / 12$ & 79 & 32 & 47 & 17 & 14 & 0,82 & 2,76 & 3,36 \\
\hline $17 / 12-21 / 12$ & -- & -- & -- & 20 & 15 & 0,75 & -- & -- \\
\hline $24 / 01-28 / 01$ & -- & -- & -- & 15 & 14 & 0,90 & -- & -- \\
\hline Média = & 61 & 37 & 24 & 13 & 10 & $\mathbf{0 , 8 3}$ & 2,18 & 2,60 \\
\hline Máximo = & $\mathbf{7 7 , 0}$ & 49,0 & 31,0 & 28 & 24 & $\mathbf{0 , 9 3}$ & 4,55 & 5,88 \\
\hline Mínimo = & 42,0 & 20,0 & 12,0 & 5 & 4 & 0,64 & 1,05 & 1,30 \\
\hline DP-médio = & 8,5 & 5,5 & 4,9 & 5 & 4 & $\mathbf{0 , 0 7}$ & $\mathbf{0 , 9 1}$ & 1,06 \\
\hline DP-Normal = & 12,8 & 6,3 & 11,6 & 5 & 4 & $\mathbf{0 , 0 8}$ & $\mathbf{1 , 0 7}$ & 1,32 \\
\hline DP-Normal = & $21 \%$ & $17 \%$ & $49 \%$ & $42 \%$ & $42 \%$ & $9 \%$ & $49 \%$ & $51 \%$ \\
\hline
\end{tabular}


Para a determinação da $f_{u p}$, é necessário determinar a fração ativa $f_{a v}$ do lodo ativado que tenha sido mantido em regime permanente e idade de lodo conhecida e constante. O sistema de testes foi montado para atender também a esta finalidade, mantendo-se então, estas condições requeridas.

No processo de determinação da $f_{a v}$, faz-se necessário a digestão aeróbia do lodo ativado em questão. Esta digestão é de no mínimo 20 dias em boas condições de aeração e controle da evaporação da água, repondo com água destilada/deionizada, e através da medida da TCO, que deve reduzir para um valor máximo de dez por cento da valor inicial.

Medindo-se as concentrações de sólidos em suspensão totais e voláteis antes e após a digestão do lodo e calculando a diferença, obtém-se o valor da $f_{a v}$. A tabela 7 traz os valores determinados antes e após a digestão. O lodo permaneceu em digestão por 22 dias, e a TCO, ao final ficou abaixo de $10 \%$ do valor inicial.

Tabela 7 - Resultados do ensaio de digestão do lodo ativado do sistema piloto

\begin{tabular}{|c|c|c|}
\hline & Inicial & Final \\
\hline TCO (mg O $2 /$ L.h $)$ & 35 & 1,3 \\
\hline $\mathrm{SSV}(\mathrm{mg} / \mathrm{L})$ & 1620 & 1115 \\
\hline
\end{tabular}

A seguir é apresentada a seqüência de cálculos para a obtenção das frações médias da carga orgânica do efluente do reator UASB do CTH, expressas em DQO, usando modelo matemático em regime permanente (Marais, G.V.R., Ekama G.A. 1976). 


\section{2 - Determinação das frações do Substrato (em DQO) do Efluente do Reator UASB}

\subsection{1 - Observações Operacionais}

Houve nitrificação no sistema piloto, o que causou dificuldades na separação física do lodo no decantador, devido à desnitrificação. Foi necessário adicionar um segundo decantador em série com o primeiro para obter uma boa separação do lodo no efluente. Isto exigiu que fosse instalada uma segunda linha de retorno para o reator, que devido às limitações de bomba, também teve o mesmo valor de vazão que do afluente, ou seja, a recirculação de lodo foi dobrada.

Também foi necessário instalar um agitador lento e temporizado no primeiro decantador, para desfazer os flocos de lodo que flotavam devido à desnitrificação. Este agitador era composto de um motor com redução ( 10 rpm) ligado a uma haste cuja extremidade era dobrada, formando uma pequena pá, chegando até o fundo do decantador. Era acionado por um circuito temporizador que mantinha o sistema ativo por dois minutos e inativo por um minuto. Este circuito teve de ser montado, devido à falta de um temporizador adequado. $\mathrm{O}$ esquema deste temporizador se encontra no Anexo D.

O lodo ativado formado no reator, aparentemente apresentava boa sedimentabilidade. Em uma proveta de $250 \mathrm{~mL}$, com $200 \mathrm{~mL}$ de amostra do lodo do reator biológico, após $30 \mathrm{~min}$. de repouso, o volume ocupado pelo lodo sedimentado era em média de cerca de $30 \mathrm{~mL}$.

No aspecto microbiológico, foi observado através de microscópio praticamente ausência de filamentos, presença de flocos dispersos e poucos microorganismos maiores (principalmente ciliados pedunculados e rotíferos), denotando um lodo tipicamente "velho" e em decadência.

\subsection{2 - Dados obtidos do Piloto de Lodos Ativados:}

- Carga Orgânica (em DQO) aplicada $=875$ mgO/d.L

- $\quad$ TRS - Tempo de Retenção de Sólidos no reator $\left(\theta_{c}\right)=10$ dias 
Dados Médios do Efluente do UASB:

$\begin{array}{lll}\text { - } & \mathrm{DQO}_{\text {total }} & =185 \mathrm{mgO} / \mathrm{L} \\ \text { - } & \mathrm{DQO}_{\text {solúvel }} & =71 \mathrm{mgO} / \mathrm{L} \\ \mathrm{DQO}_{\mathrm{p}} & =114 \mathrm{mgO} / \mathrm{L}\end{array}$

Dados Médios do Efluente do Piloto L.A. :

- $\mathrm{DQO}_{\text {total }}=61 \mathrm{mgO} / \mathrm{L}$

- DQO $_{\text {solúvel }} \quad=37 \mathrm{mgO} / \mathrm{L}=\mathrm{DQO}_{\mathrm{snb}} \Rightarrow f_{\text {us }}=37 / 185 \Rightarrow f_{\boldsymbol{u s}}=\mathbf{0 , 2 0}$

- $\mathrm{DQO}_{\mathrm{p}}=24 \mathrm{mgO} / \mathrm{L}$

No Reator (após oito meses de operação em regime permanente):

- $\mathrm{SST} \quad=2.693 \mathrm{mgSST} / \mathrm{L}$

- $\mathrm{SSV} \quad=2160 \mathrm{mgSSV} / \mathrm{L}$

- $\mathrm{SSV} / \mathrm{SST} \quad=0,80$

5.2.3 - Determinação de $f_{a v}$ através da digestão aeróbia do lodo ativado

$f_{a v}=\left(X_{v i}-X_{v \infty}\right) /\left[X_{v i} \cdot\left(1-f_{E}\right)\right]$ (Marais e Ekama, 1976)

Dado inicial $-\mathrm{SSV}\left(\mathrm{X}_{\mathrm{vi}}\right)=1620 \mathrm{mgSSV} / \mathrm{L}$

Após digestão $-\mathrm{SSV}\left(\mathrm{X}_{\mathrm{v} \infty}\right)=1115 \mathrm{mgSSV} / \mathrm{L}$

Valor adotado $f_{E}=0,20$

$f_{a v}=(1620-1115) /[1620 \cdot(1-0,20)]=0,39$

5.2.4 - Cálculo de $f_{u p}$ :

- Equações do definidas no Modelo em Regime Permanente (Marais e Ekama, 1976):

$f_{u p}=X_{i a} \cdot f_{c v} / S_{t a} \Rightarrow X_{i a}=S_{t a} \cdot f_{u p} / f_{c v}$

$M S_{b a}=Q \cdot\left(S_{t a}-S_{u s a}-X_{i a} \cdot f_{c v}\right)$ 


$$
\begin{aligned}
& M X_{B, H}=M S_{b a} \cdot Y_{h} \cdot \theta_{c} /\left(1+b_{h} \cdot \theta_{c}\right) \\
& M X_{E}=f_{E} \cdot b_{h} \cdot \theta_{c} \cdot M X_{B, H} \\
& M X_{I}=f_{u p} \cdot \theta_{c} \cdot M S_{t i} / f_{c v} \\
& M X_{v}=M X_{B, H}+M X_{E}+M X_{I} \\
& M O_{c}=M S_{b a} \cdot\left(1-f_{c v} \cdot Y_{h}\right)+\left(1-f_{E}\right) \cdot b_{h} \cdot f_{c v} \cdot M X_{B, H} \\
& f_{a v}=M X_{B, H} / M X_{v}
\end{aligned}
$$

Considerando as massas em $1 \mathrm{~L}$

- Determinação de $M X_{B, H}$ :

$$
\begin{aligned}
& f_{a v}=M X_{B, H} / M X_{v} \\
& f_{a v}=0,39 \\
& M X_{B, H}=f_{a v} . M X_{v}=0,39.2160 \Rightarrow M X_{B, H}=842,4 \mathrm{mgSSV}
\end{aligned}
$$

- Determinação de $M X_{E}$ :

$M X_{E}=f_{E} \cdot b_{h} \cdot \theta_{X} \cdot M X_{B, H}$

$f_{E}=0,20$ (conforme Ekama, G. A., Dold, P. L. \& Marais, G. V. R. - 1986)

$b_{h}=0,24$ (conforme Ekama, G. A., Dold, P. L. \& Marais, G. V. R. - 1986)

$\theta_{c}=10$ dias

$M X_{E}=0,20.0,24.10 .842,4=>M X_{E}=404,3 \mathrm{mgSSV}$

- $\quad$ Determinação de $M X_{I}$ :

$M X_{v}=M X_{B, H}+M X_{E}+M X_{I}$ 
$M X_{I}=2160-842,4-404,3=>M X_{I}=913,2 \mathrm{mgSSV}$

- Determinação da $f_{u p}$ :

$M X_{I}=f_{u p} \cdot \theta_{c} \cdot M S_{t i} / f_{c v}$

$f_{u p}=M X_{I} \cdot f_{c v} / \theta_{c} \cdot M S_{t i}$

$f_{c v}=1,48$ (adotado por ser largamente utilizado )

$f_{u p}=913,2.1,48 / 10.875=>f_{u p}=0,154$

\subsection{5 - Resultados Finais:}

$f_{u s}=\mathbf{0 , 2 0}$
$f_{u p}=\mathbf{0 , 1 5 4}$
$f_{b}=\mathbf{0 , 6 4 6}$
$f_{r b} \sim \mathbf{0}$ (não detectável pelo método respirométrico)

\subsection{6 - Comparativo dos Resultados Finais:}

Podemos comparar os valores encontrados neste trabalho com os da literatura, tomando como base as mesmas referências (IAWQ - 1998, van Haandel e Marais 1999), de forma a conseguir uma visão mais clara das diferenças encontradas.

Observa-se na tabela 8 , que tanto no caso de esgoto doméstico bruto quanto no decantado, há valores bem diferentes nas frações. Em ambos os casos, há a presença de matéria orgânica rapidamente biodegradável e também uma grande diferença na fração biodegradável. No caso do esgoto decantado, devido a remoção de boa parte do material particulado, a $f_{u p}$ deste efluente é bem menor que a do efluente do UASB estudado. 
O fato de encontrar uma baixa concentração de matéria orgânica no efluente do UASB (DQO média de $185 \mathrm{mgO} / \mathrm{L}$ ), já era esperado. Todavia, o que se verificou também, foi uma grande diferença na distribuição desta matéria orgânica, como por exemplo a fração de material orgânico solúvel não biodegradável.

As diferenças na $f_{u p}$ e $f_{u s}$ sem sombra de dúvida, tem uma grande influência em um projeto de pós - tratamento. Por exemplo, a geração de lodo e de biomassa ativa, (sendo que esta última tem como conseqüência o consumo de oxigênio) serão bem diferentes se usados os valores encontrados na literatura para esgotos domésticos. Também o rendimento teórico esperado em termos de eficiência de remoção de DQO será menor, comparado com a literatura.

Como para o projeto de reatores aeróbios necessita-se principalmente destes valores, torna-se fundamental o conhecimento dos mesmos, que neste caso não poderiam ser encontrados na literatura até o momento.

Finalizando, como os resultados mostram uma concentração desprezível (não detectada) de matéria orgânica rapidamente biodegradável, não há como ter uma boa eficiência com sistemas de pós - tratamento para a remoção de nutrientes, como discutido anteriormente, na revisão da literatura neste trabalho.

Tabela 8 - Valores das frações de DQO para esgotos tipicamente domésticos e os encontrados para o efluente de UASB

Tipos de Afluentes

\begin{tabular}{cccc}
\hline Fração & Esgoto Bruto* & Esgoto Decantado* & UASB \\
\hline$f_{r b}$ & 0,20 & 0,25 & $\sim 0,0$ \\
\hline$f_{u s}$ & 0,05 & 0,08 & 0,20 \\
\hline$f_{u p}$ & 0,13 & 0,04 & 0,15 \\
\hline$f_{b}$ & 0,82 & 0,88 & 0,65 \\
\hline
\end{tabular}

* Valores encontrados na literatura. 


\section{CONCLUSOES E RECOMENDAÇÕES}

Do trabalho desenvolvido para o efluente do reator UASB implantado no CTH da Cidade Universitária da USP, tratando esgoto do CRUSP e do restaurante da COSEAS, apresentou um efluente, com as seguintes características médias:

- $\mathrm{DQO}_{\text {total }} \quad=185 \mathrm{mgO} / \mathrm{L}$

- $\mathrm{DQO}_{\text {solúvel }}=71 \mathrm{mgO} / \mathrm{L}$

- $\mathrm{DQO}_{\mathrm{p}} \quad=114 \mathrm{mgO} / \mathrm{L}$

- Apenas uma fração de cerca de 65\% da matéria orgânica do efluente do UASB, contra $85 \%$ para esgoto bruto/decantado expressa em DQO é biodegradável, e em relação à não biodegradável cerca de $15,4 \%$ é particulada e $20 \%$ solúvel.

- A DQO ${ }_{\text {usa }}$ parece ser muito próxima do registrado no efluente de estações de tratamento de esgotos por Lodos Ativados $(\sim 37 \mathrm{mg} \mathrm{O} / 2 / \mathrm{L})$. No caso do efluente de UASB foi em média, mais de $50 \%$ da fração solúvel.

- A concentração de SS do efluente do UASB apresentou um desvio padrão de $52 \%$ em relação à média.

- As curvas de TCO na maioria não foram conclusivas e, as poucas que foram possíveis de avaliar (apenas duas de quatorze) apresentaram uma curva ascendente, característica de hidrólise da matéria orgânica do afluente. Porém, como os experimentos não foram conduzidos com este intuito, não foi possível determinar a constante de hidrólise e a taxa máxima da mesma.

- Os resultados indicam (sem matéria orgânica rapidamente biodegradável) maiores dificuldades para sistemas com desnitrificação e/ou remoção biológica de fósforo. 


\section{Recomendações}

- Os valores obtidos são para o uso no modelo simplificado para Lodos Ativados do grupo de pesquisas da UCT (Marais e Ekama, 1976).

- Para um melhor entendimento e validade destes resultados, é necessário repetir este ensaio, com efluentes de outros reatores UASB representativos de esgoto urbano.

- Com base na experiência aqui obtida, pode-se dirigir um novo experimento para a tentativa de determinar a taxa de hidrólise, que ao que tudo indica é o fator limitante neste processo.

- É necessário ressaltar que a designação de não biodegradável para as frações de DQO que foram estudadas, se referem a um sistema de Lodos Ativados operando com $\theta_{c}=10$ dias. Logo, mesmo se alguma substância insolúvel for biodegradável, ainda que muito lentamente, ou seja, levar mais de dez dias para ser oxidada, para este sistema será entendida ou identificada como não biodegradável.

- No caso do uso dos valores aqui obtidos para um outro reator UASB, é importante lembrar que, se as características do efluente forem muito diferentes, como por exemplo sólidos suspensos, torna-se necessário usar estes mesmos dados referenciados à média de sólidos que foi encontrada neste experimento, chegando a outras formas de expressar os mesmos valores, como no caso da $f_{u s}$ que foi encontrada como $20 \%$ da DQO total, mas foi também em média $50 \%$ da DQO solúvel. Como a perda de sólidos é provavelmente o fator mais sujeito a variações, este interferirá no valor total da DQO, mas não na razão da $\mathrm{DQO}_{\mathrm{us}} / \mathrm{DQO}_{\text {solúvel. }}$ 


\section{Referências Bibliográficas}

ALEM SOBRINHO, P. Estudo dos fatores que influem no desempenho do processo de lodos ativados - determinação de parâmetros de projeto para esgotos predominantemente domésticos. Revista DAE, n. ${ }^{\circ}$ 132, p. 49 - 70, 1983

ANDREOTTOLA, GIANNI; DE OLIVEIRA, EDUARDO LUIZ; FOLADORI, PAOLA; DALLAGO, LORIS; PETERLINI, ROBERTO e CADONNA, MARIA Método respirométrico para o monitoramento de processos biológicos. Revista de engenharia Sanitária e Ambiental, n. ${ }^{\circ}$ 01, vol. 10, p.14 - 23, 2005

CHERNICARO, C. A. L.; VAN HAANDEL, A.; AISSE, M. M. e CAVALCANTI, P. F. F. Reatores anaeróbios de manta de lodo. In: CAMPOS J.R. Tratamento de esgotos sanitários por processo anaeróbio e disposição controlada no solo, Rio de Janeiro: ABES, 1999, $1^{\text {a }}$ ed., p.155 - 198.

EKAMA, G. A., DOLD, P. L.; MARAIS, G. V. R. Procedures for determining influent COD fractions and the maximum specific growth rate of heterotrophs in Activated Slugde Systems; Wat. Sci. Tech., Copenhagen, Vol. 18, p. 91-114, 1986

FORESTI, E.; FLÔRENCIO, L.; VAN HAANDEL, A.; ZAIAT, M.;

CAVALCANTI, P. F. F. Fundamentos do tratamento anaeróbio. in: CAMPOS J.R. Tratamento de esgotos sanitários por processo anaeróbio e disposição controlada no solo, Rio de Janeiro: ABES, 1999, 1ª ed., p.29 - 52.

KATO, M. T.; NETO, C. O. A.; CHERNICARO, C. A. L.; FORESTI, E. e CYBIS, L. F. Configurações de reatores anaeróbios. in: CAMPOS J.R. Tratamento de esgotos sanitários por processo anaeróbio e disposição controlada no solo, Rio de Janeiro: ABES, 1999, $1^{\text {a }}$ ed., p.53 - 99.

MARAIS, G. V. R.; EKAMA, G. A. The activated sludge process - part 1 steady state behavior; Water S. A., Cape Town, v.2, n.4, p.163-200, 1976

METCALF \& EDDY. Wastewater engineering - treatment, disposal and reuse; $4^{\text {th }}$ ed. Boston, Lodon: McGraw Hill, c2003. 1819p. 
CHERNICHARO, C.A.L. Pós - tratamento de efluentes de reatores anaeróbios, Belo Horizonte - FINEP - $20011^{\mathrm{a}}$ ed.

CAMPOS, J. R. Tratamento de esgotos sanitários por processo anaeróbio e disposição controlada no solo, Rio de Janeiro - ABES - $19991^{\text {a }}$ ed.

FOGLER, H.S. Elements of Chemical Reaction Engineering, New Jersey - PrinticeHall $-19922^{\circ}$ edition, p. $709-803$.

LEVENPIEL, O. Chemical Reaction Engineering, New York - John Wiley \& Sons $-19722^{\circ}$ edition, p. $75-132$.

ROS, M. Respirometry of Activated Sludge, Thechnomic Publishing Company Inc., n.a, 1993 p.135

ROZICH ALAN F. e GAUDY JR. A. F. Design and operational of activated slugde processes using respirometry. Lewis Publishers Inc., Michigan, 1992 p.186

SPANJERS H., VANROLLEGHEM P.A., OLSSON G., DOLD P.L. Respirometry in control of the activated slugde process: principles, scientific and technical report series. n 7, IAWQ, n.a, 1998

VAN HAANDEL A., MARAIS G.R.V. O comportamento do sistema de lodo ativado. Campina Grande - epgraf , $1^{\text {a }}$ ed. c1999, 472p.

VON SPERLING, M., Princípios do tratamento biológico de águas residuárias lodos ativados.2 $2^{\text {a }}$ ed. Belo Horizonte, v. 4, c1997, 416p.

WENTZEL MC, MBEWE A. and EKAMA, G.A. Batch test for measurement of readily biodegradable cod and active organism concentrations in municipal waste waters. Water S.A. v. 21, nº 2, 1995 
WENTZEL MC, MBEWE A. and EKAMA, G.A. Characterisation of the carbonaceous materials in municipal wastewaters waste waters. Water S.A. v. 25, $\mathrm{n}^{\circ}$ 3, 1999 
ANEXO A - Gráfico do comportamento de reatores

Comparativo de comportamento hidráulico de reatores de Mistura completa e Fluxo Pistão diante da injeção pontual de um traçador

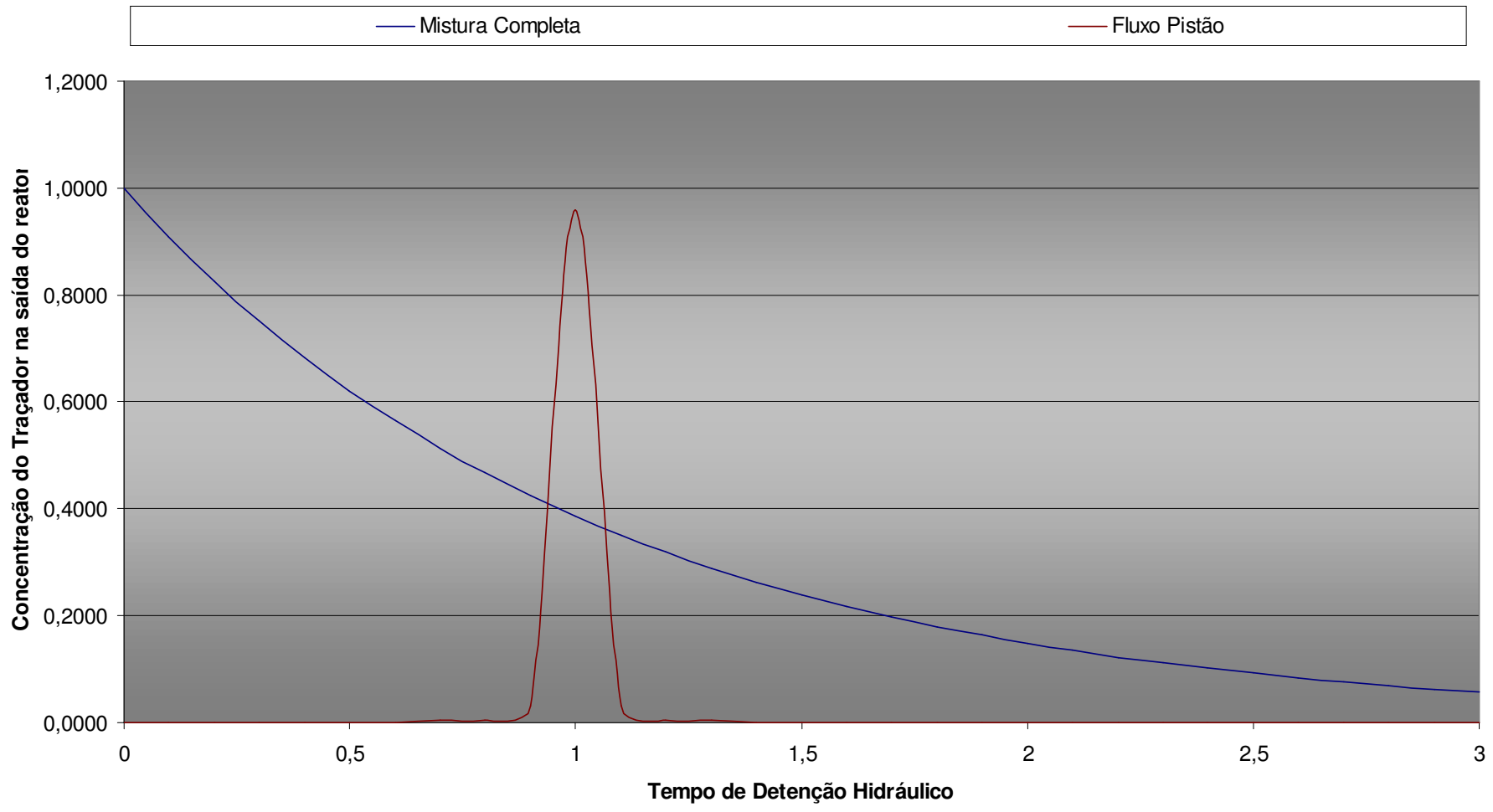


ANEXO B - Monitoramento do Efluente do UASB do CTH - Realizado pelo laboratório de engenharia sanitária da Escola Politécnica-USP.

\begin{tabular}{ccccc}
\hline Data & $\begin{array}{c}\mathrm{t} \\
\text { (dias) }\end{array}$ & $\begin{array}{c}\text { DQO } \\
\text { entr }\end{array}$ & $\begin{array}{c}\text { DQO } \\
\text { Saída }\end{array}$ & $\begin{array}{c}\text { DQO } \\
\text { S.fillt }\end{array}$ \\
\hline $3 / 10 / 2002$ & 1 & 450,6 & 70 & 11 \\
\hline $9 / 10 / 2002$ & 7 & 880 & 480 & 140 \\
\hline $22 / 10 / 2002$ & 20 & 560 & 215 & 184 \\
\hline $25 / 10 / 2002$ & 23 & 676 & 180 & 104 \\
\hline $30 / 10 / 2002$ & 28 & 688 & 164 & 60 \\
\hline $6 / 11 / 2002$ & 35 & 640 & 170 & 50 \\
\hline $13 / 11 / 2002$ & 42 & 360 & 216 & 112 \\
\hline $21 / 11 / 2003$ & 50 & 505 & 211 & 108 \\
\hline $27 / 11 / 2003$ & 56 & 512 & 204 & 64 \\
\hline $11 / 12 / 2002$ & 70 & 615 & 250 & 77 \\
\hline $15 / 1 / 2003$ & 105 & 650 & 250 & 108 \\
\hline $4 / 2 / 2003$ & 125 & 440 & 108 & 64 \\
\hline $7 / 2 / 2003$ & 128 & 180 & 112 & \\
\hline $12 / 2 / 2003$ & 133 & 584 & 168 & 60 \\
\hline $14 / 2 / 2003$ & 135 & 520 & 160 & \\
\hline $19 / 2 / 2003$ & 140 & 530 & 180 & 65 \\
\hline $21 / 2 / 2003$ & 142 & 550 & 175 & 102 \\
\hline $26 / 2 / 2003$ & 147 & 581,44 & 198,72 & 143 \\
\hline $12 / 3 / 2003$ & 161 & 675,84 & 192 & 77 \\
\hline $14 / 3 / 2003$ & 163 & 545,28 & 115,2 & \\
\hline $19 / 3 / 2003$ & 168 & 645,12 & 134,4 & 73 \\
\hline Média & 5 & 561,3 & 188,3 & 89,0 \\
\hline & & & &
\end{tabular}

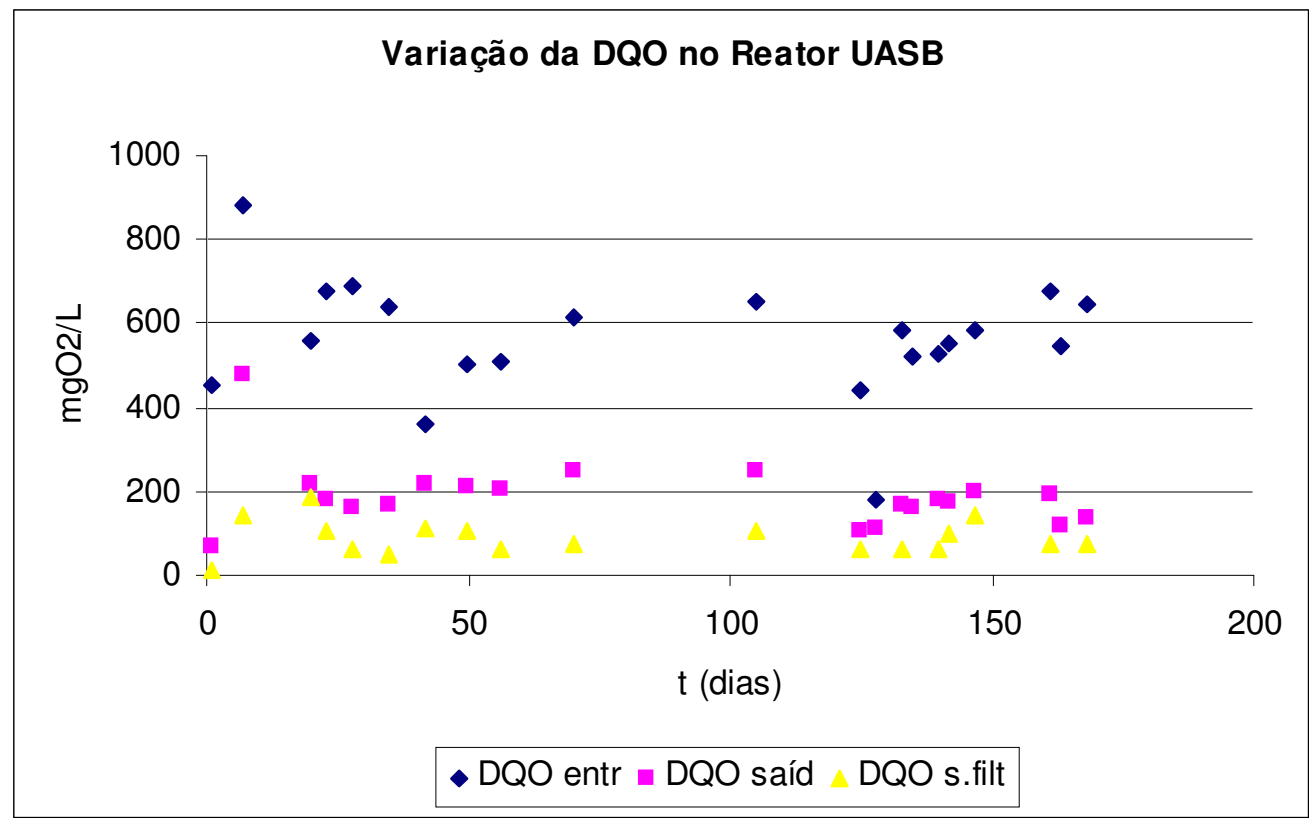


ANEXO C - Fotos do sistema de lodos ativados em escala de Laboratório

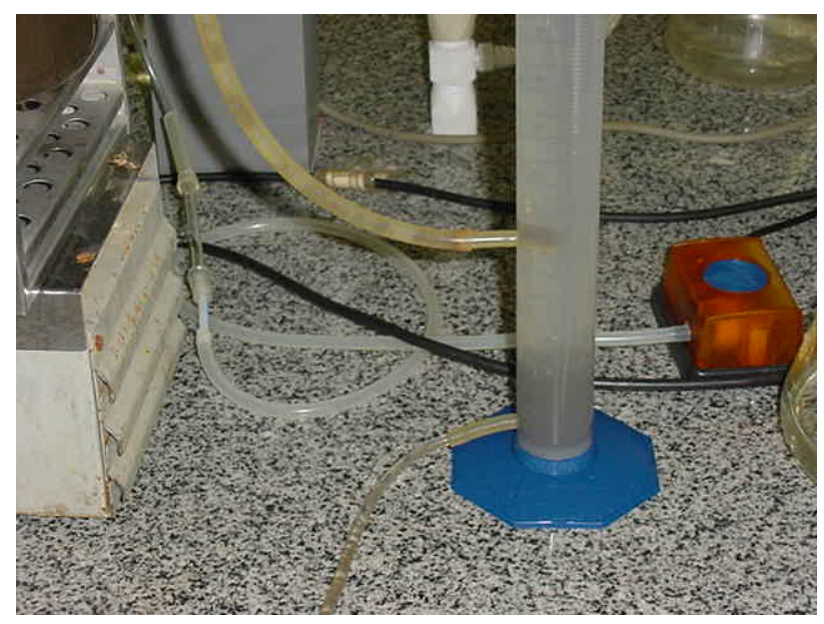

Detalhe do decantador cilíndrico

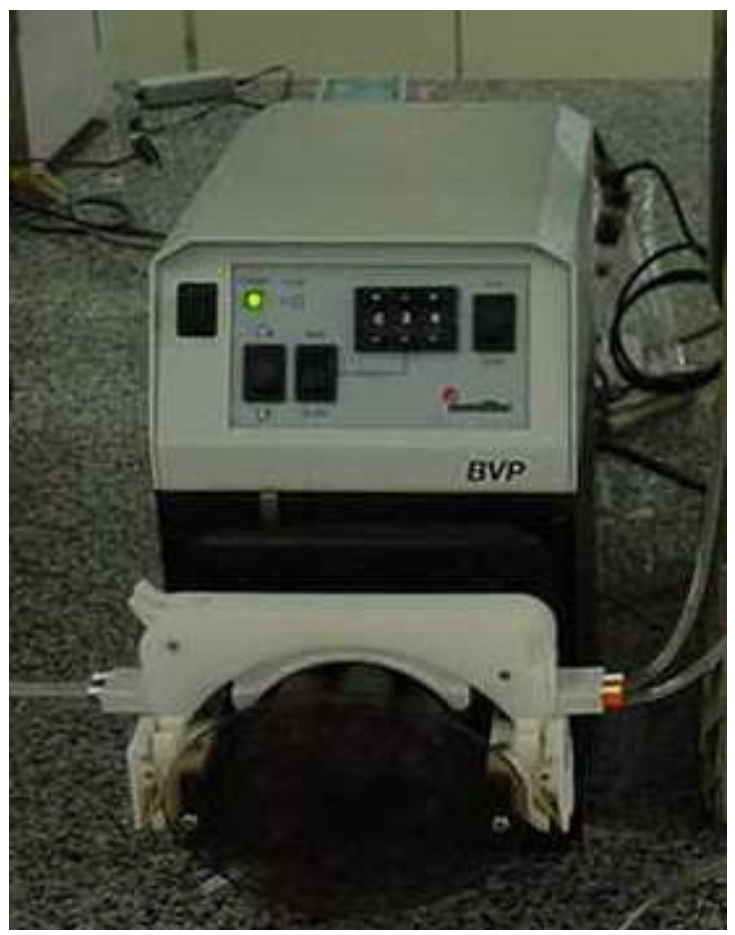

Bomba peristáltica de velocidade variável 
ANEXO D - Gráfico do comportamento do conteúdo do reator de lodos ativados em escala Piloto

Valores encontrados no conteúdo do reator de lodos ativados

口SST $\square S S V$

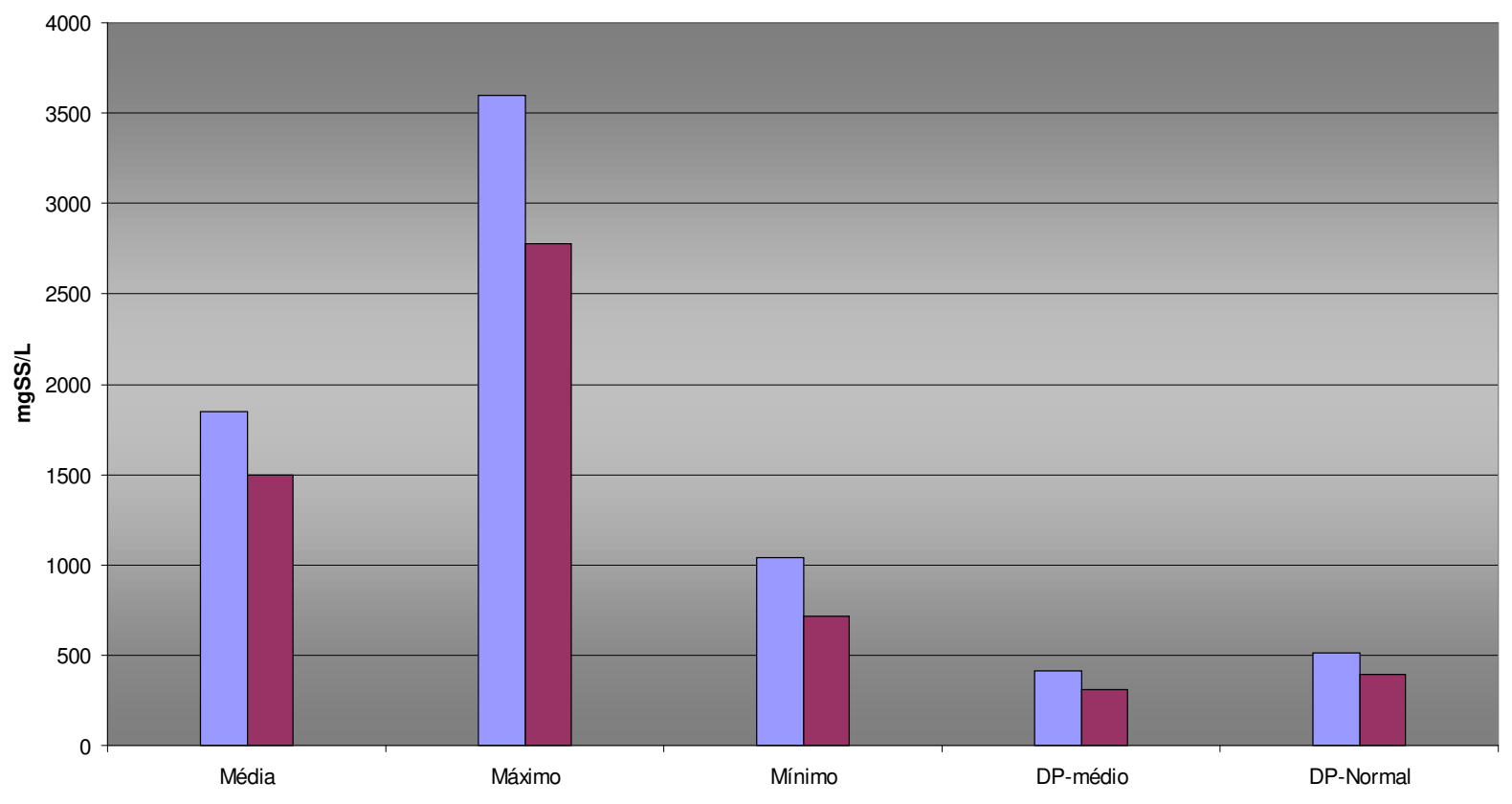


ANEXO E - Esquema do Circuito eletrônico temporizador

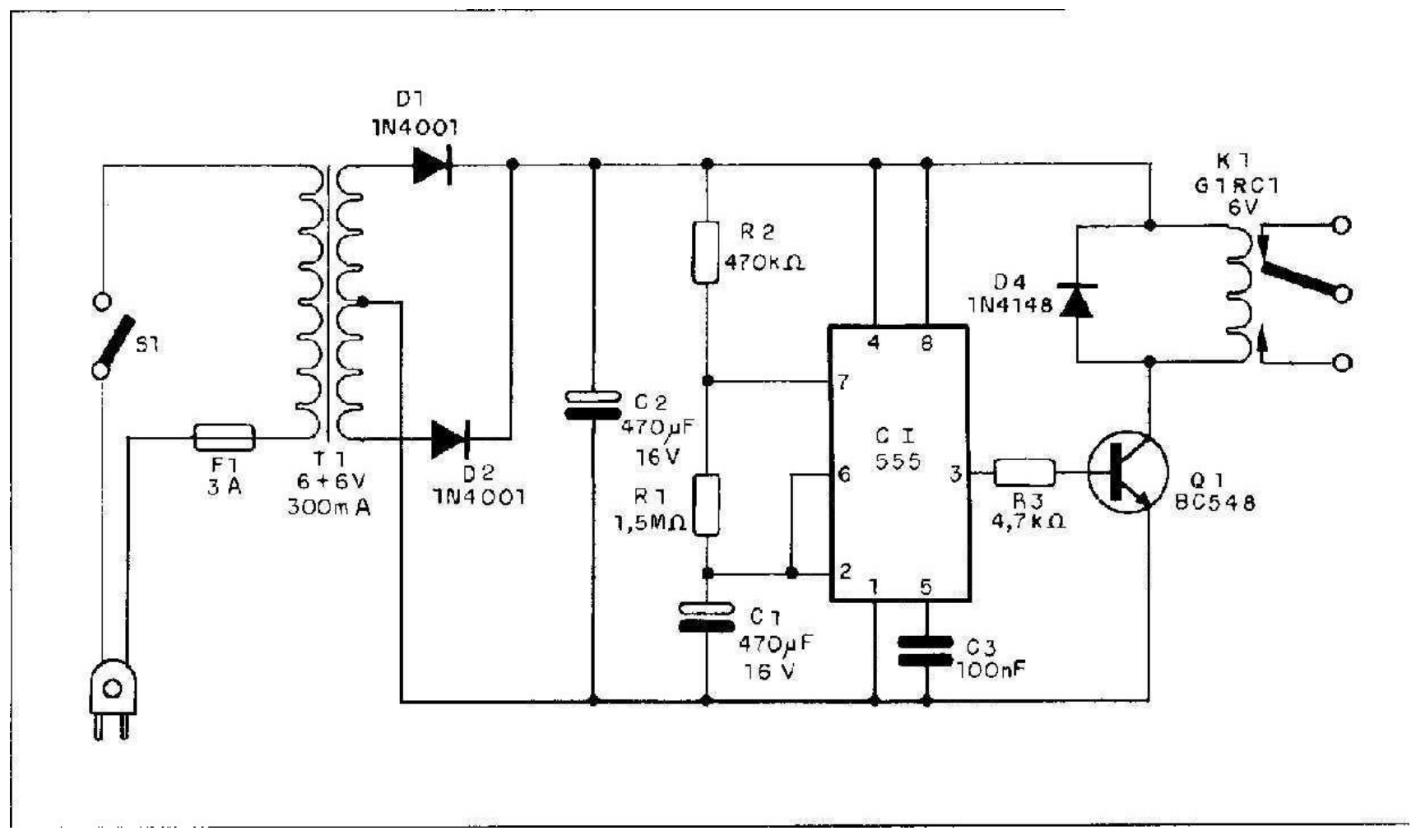

